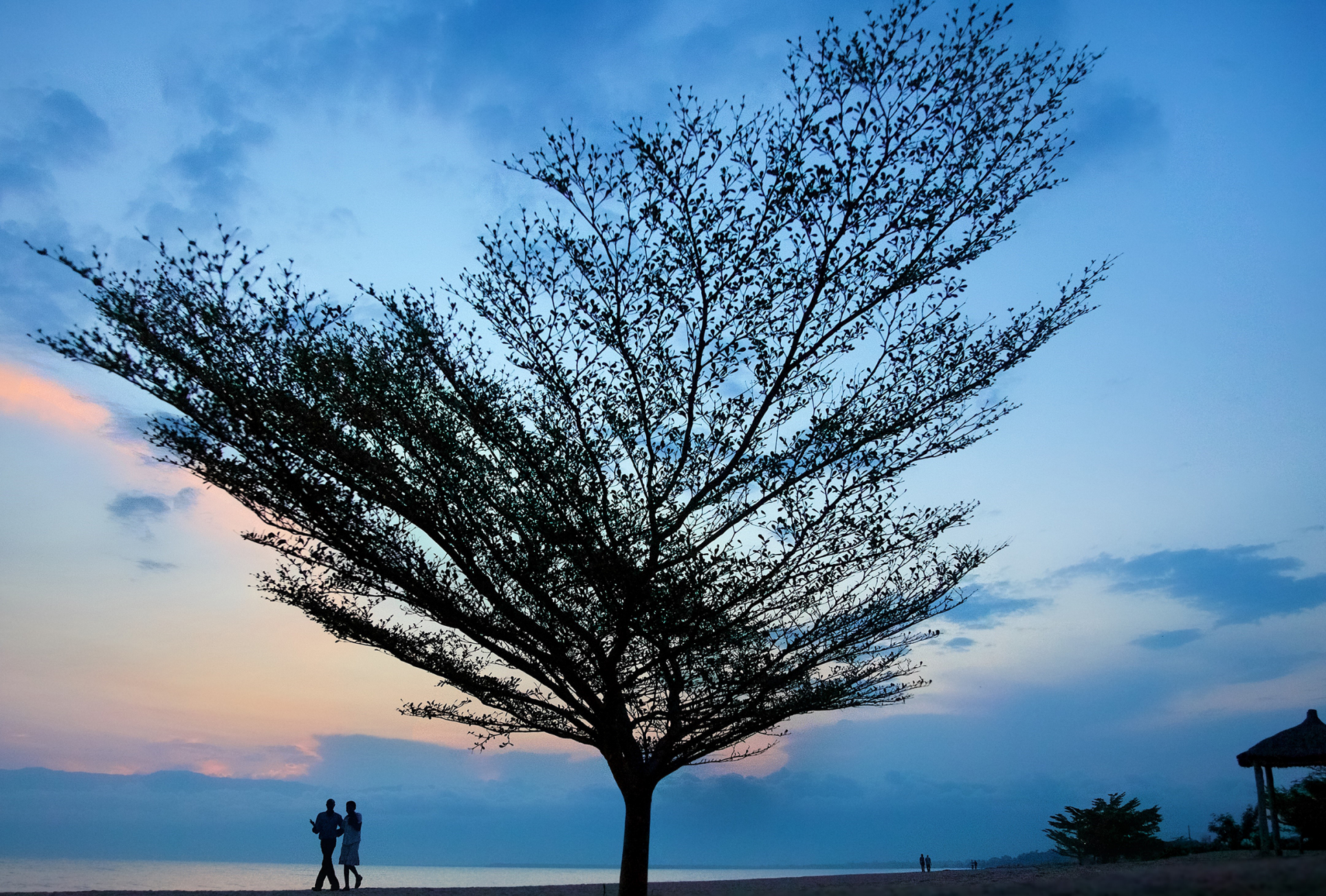

WORLD BANK EDUCATION, TECHNOLOGY \& INNOVATION SABER-ICT Technical Paper Series

\title{
The Role and Status of National Research and Education Networks (NRENs) in Africa
}

Michael Foley 2016 



\section{The Role and Status of National Research and Education Networks (NRENs) in Africa}

World Bank Education, Technology \& Innovation:

SABER-ICT Technical Paper Series (\#05)

Michael Foley

2016 
To cite this publication:

Foley, M. 2016. The Role and Status of National Research and Education Networks (NRENs) in Africa.

World Bank Education, Technology \& Innovation: SABER-ICT Technical Paper Series (\#05).

Washington, DC: The World Bank.

Available at: http://saber.worldbank.org

cover image: Lake Tanganyika, from Bujumbura, Burundi @ (Michael Foley 2012. Used with permission.

\section{(c) (1) \\ Rights and Permissions}

This work is available under the Creative Commons Attribution 3.0 IGO license (CC BY 3.0 IGO)

http://creativecommons.org/licenses/by/3.0/igo. Under the Creative Commons Attribution license, you are free to copy, distribute, transmit, and adapt this work, including for commercial purposes, under the following conditions:

Attribution-Please cite the work as follows: Foley, M. 2016. The Role and Status of National Research and Education Networks (NRENs) in Africa. World Bank Education, Technology \& Innovation: SABER-ICT Technical Paper Series (\#05). Washington, DC: The World Bank. License: Creative Commons Attribution CC BY 3.0 IGO

Translations-If you create a translation of this work, please add the following disclaimer along with the attribution: This translation was not created by The World Bank and should not be considered an official World Bank translation. The World Bank shall not be liable for any content or error in this translation.

Adaptations-If you create an adaptation of this work, please add the following disclaimer along with the attribution: This is an adaptation of an original work by The World Bank. Views and opinions expressed in the adaptation are the sole responsibility of the author or authors of the adaptation and are not endorsed by The World Bank.

Third-party content-The World Bank does not necessarily own each component of the content contained within the work. The World Bank therefore does not warrant that the use of any third-party-owned individual component or part contained in the work will not infringe on the rights of those third parties. The risk of claims resulting from such infringement rests solely with you. If you wish to re-use a component of the work, it is your responsibility to determine whether permission is needed for that re-use and to obtain permission from the copyright owner. Examples of components can include, but are not limited to, tables, figures, or images.

(C) 2016 International Bank for Reconstruction and Development / The World Bank 1818 H Street NW, Washington DC 20433 USA

Telephone: +1-202-473-1000; Internet: www.worldbank.org

Some rights reserved

Disclaimer: The findings, interpretations, and conclusions expressed in this work do not necessarily reflect the views of The World Bank, its Board of Executive Directors, or the governments they represent. The World Bank does not guarantee the accuracy of the data included in this work. The boundaries, colors, denominations, and other information shown on any map in this work do not imply any judgment on the part of The World Bank concerning the legal status of any territory or the endorsement or acceptance of such boundaries. Nothing herein shall constitute or be considered to be a limitation upon or waiver of the privileges and immunities of The World Bank, all of which are specifically reserved. 


\section{Table of Contents}

1. Introduction, Background \& Overview

2. The Emergence of NRENs

- The Nature and Role of NRENs......

- Who Uses NRENs and For What?

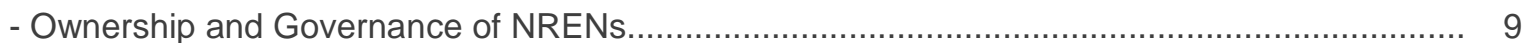

- Funding and Business Models.................................................................................... 9

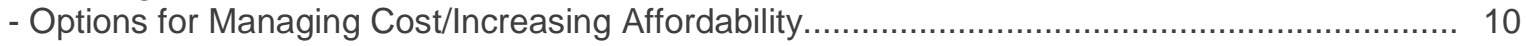

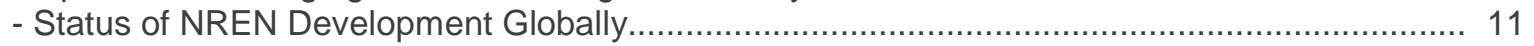

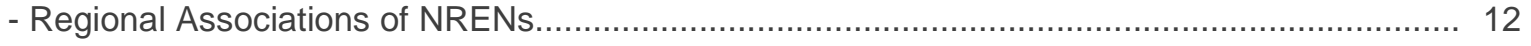

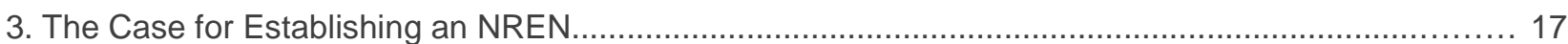

- The Economic Case for an NREN: Aggregation of Demand and Value for Money................... 17

- Advanced Services - Supporting Collaboration and Facilitating Access.................................. 19

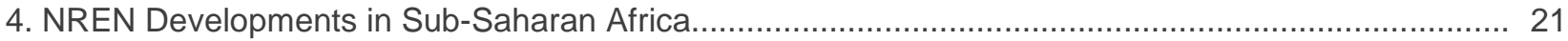

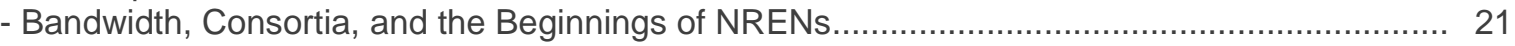

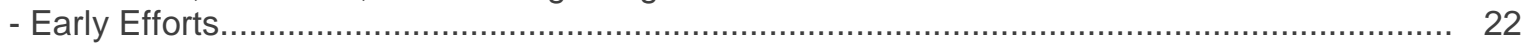

- The Regional Research and Education Networks (RENs) ............................................... 23

- The AfricaConnect Project - A Catalyst for the Growth of NRENs in Africa............................ 26

- Capacity-Building Programs and Projects Supporting NREN Services Development in Africa. 27

5. Status of the NRENs of Africa by Region (June 2016) .............................................................. 29

- Stages of Development of African NRENs...................................................................... 29

- Examples of NREN Topology in Nigeria and Kenya ........................................................ 34

- NREN Status and International REN-REN Connectivity in Africa (June 2016)....................... 35

- Plans for the Future: AfricaConnect2 (July 2015_December 2018) .................................. 37

6. Trends and Prospects in the Use of NRENs........................................................................... 39

- Teaching, Learning, and Research in a Digital Age ......................................................... 39

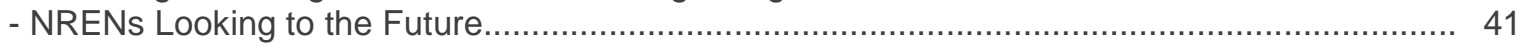

- Expanding the Community and Responding to Global Challenges........................................ 42

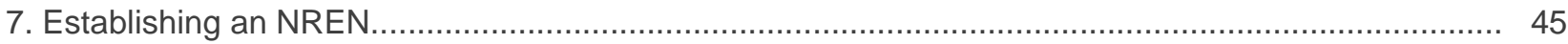

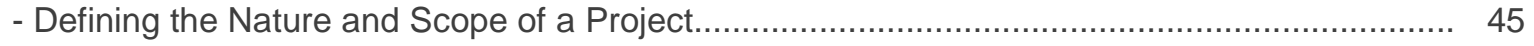

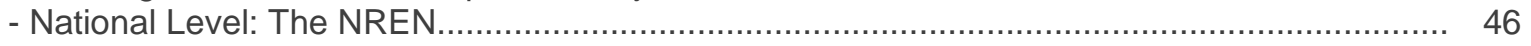

- Institutional Level: Campus Networks, IT Services, and Digital Literacy.............................. 47

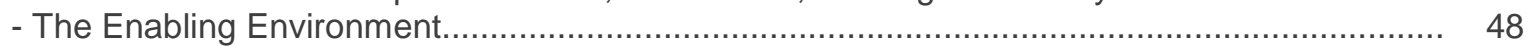

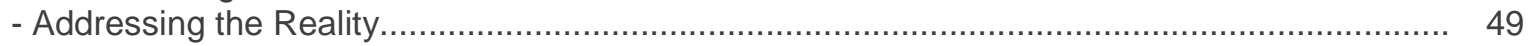

- Actions to Establish an NREN...................................................................................... 49

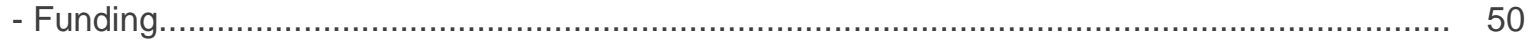

- Cost Headings in a Changing Environment................................................................... 51

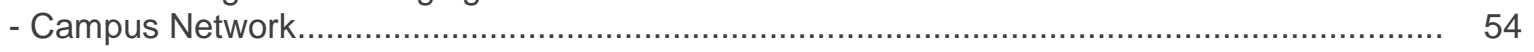

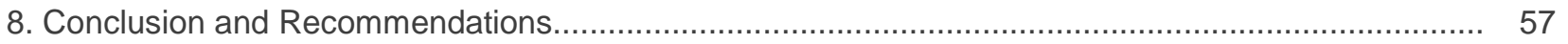

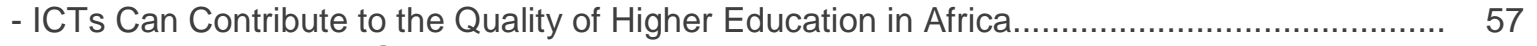

- Recommendations to Governments......................................................................... 58

- Recommendations to Private Sector and Telecom Sector............................................. 59

- Recommendations to Higher Education Institutions...................................................... 59

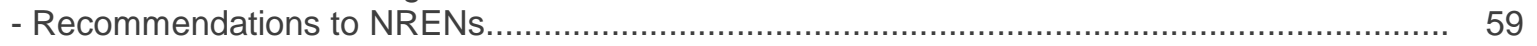

- Recommendations to Development Partners.............................................................. 60

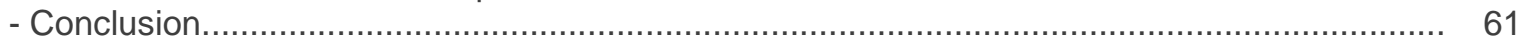


Annex A. Country by Country African NREN Status

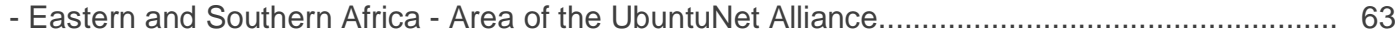

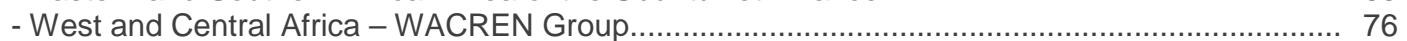

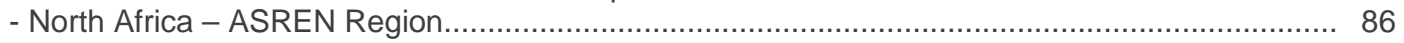

Annex B. AfricaConnect Projects

- AfricaConnect, Phase One: May 2010-June 2015: Project Scope.................................... 91

- AfricaConnect, Phase Two: July 2015-December 2018: Project Scope.............................. 92

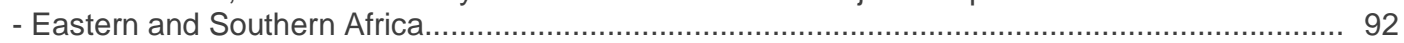

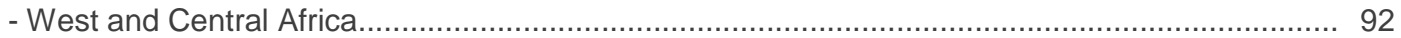

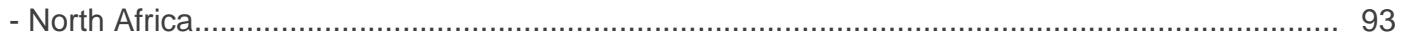

Annex C. Capacity-Building Programs and Projects Supporting NREN Services Development in Africa

- TANDEM (Trans African Network Development)

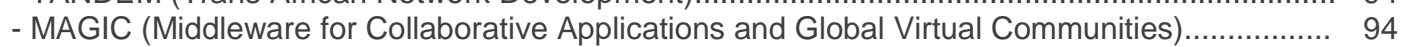

- Sci-GalA (Energizing Scientific Endeavour through Science Gateways and e-Infrastructures in Africa).

- Cyber Security; AfricaProtect; African Cyber Security Research \& Threat Intelligence

Collective....

- Authentication and Authorization Infrastructures.

- FaaS - Enabling NRENs to Operate An Identity Federation........................................... 95

- Campus Networking - An Essential Building Block of a National Network................................ 96

\section{Boxes, figures and tables}

Box 1. Beyond Connectivity - Other Services Provided by an NREN

Figure 1. Funding Models of NRENs in the GÉANT Area

Figure 2. Countries with Operational NRENs or In Advanced Planning for One

Figure 3. Topology of the NREN Interconnections in APAN

Figure 4. Inter-regional Links between GÉANT and the Rest of the World C

Figure 5. RedClara Topology Courtesy of RedClara.

Figure 6. GLORIAD Science and Education Network

Figure 7. Submarine Fiber Cables Reaching Africa, Up To 2018

Figure 8. UbuntuNet Alliance - Levels of Development of NRENs in Eastern and Southern Africa based on the Capability Maturity Model (CMM)

Figure 9. WACREN - Levels of Development of NRENs in West and Central Africa based on the CMM

Figure 10. ASREN - Levels of Development of NRENs in North Africa based on the CMM Figure 11. NgREN, Nigeria, Network Topology

Figure 12. KENET, Kenya Network Topology

Figure 13. Levels of Development and Connectivity of African NRENs

Table 1. List of Countries in Africa and their NREN Status 


\section{Acronyms \& abbreviations}

AAl: Authentication and Authorization Infrastructure

AAU: Association of African Universities

AfNOG: African Network Operators Group

AfREN: Africa Research and Education Network

APAN: Asia Pacific Advanced Network

ASREN: Arab States Research and Education Network

AUP: Acceptable Use Policy

CAREN: Central Asian Research and Education Network

CNIM: Common NREN Information Model

DANTE: Delivery of Advanced Network Technology to Europe

DNS: Domain Name System

EU: European Union

FaaS: Federation as a Service

HEMIS: Higher Education Management Information System

ICT: Information and Communication Technology

IDRC: International Development Research Center

IP: Internet Protocol

IRU: Indefeasible Right of Use

ISP: Internet Service Provider

LMS: Learning Management System

MAGIC: Middleware for Collaborative Applications and Global Virtual Communities

MOOC: Massive Open Online Course

NOC: Network Operations Center

NREN: National Research and Education Network

NSRC: Network Startup Resource Center

PoP: Point of Presence

REN: Research and Education Network

RNP: Rede Nacional de Ensino e Pesquisa

SIDA: Swedish International Development Cooperation Agency

SSO: Single Sign-On

TERENA: Trans-European Research and Education Networking Association

UAF: Universal Access Fund

VSAT: Very Small Aperture Terminal

WACREN: West and Central African Research and Education Network 


\section{Acknowledgements}

The World Bank Education, Technology \& Innovation: SABER-ICT Technical Paper Series explores a variety of topics and issues related to the use of information and communication technologies (ICTs) in the education sector.

The Systems Approach for Better Education Results (SABER) initiative seeks to improve the global knowledge base related to education systems analyses, assessments, diagnoses, and opportunities for dialogue. SABER-ICT aims to improve the availability of policy-related data, information, and knowledge on what matters most in using ICTs to improve the quality of education.

This publication series is made possible through generous support from the Government of Korea, most notably through the Korea - World Bank Partnership Facility.
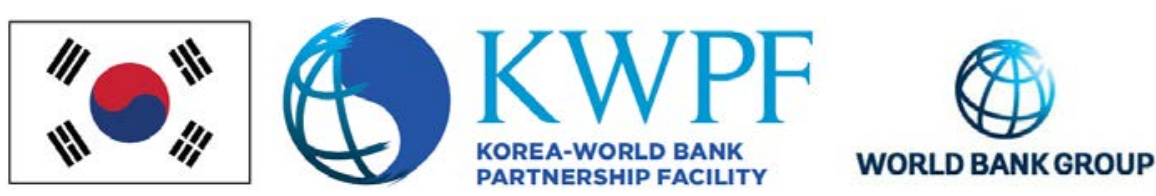

This paper, The Role and Status of National Research and Education Networks (NRENs) in Africa, was made possible through support from the Multi-Donor Education and Skills Fund (MESF) managed by the World Bank. It was commissioned by Sukhdeep Brar and supervised by Ryoko Tomita (World Bank). 
Note: As it is envisaged that the report may not be read in sequence, there is some necessary repetition of content between sections. The report is aimed at non-technical readers and hence the language used is, as much as possible, free of technical jargon, with explanations in lay person terms where necessary. 


\section{Executive summary}

The aim of this report is to provide guidance to governments, institutions, and development partners on how to approach the provision of advanced information and communication technology (ICT) services to the higher education and research community in Africa. The timing is appropriate as it coincides with a transformation in the telecom infrastructure and services on the continent as fiber optic connectivity, both undersea and on land, is expanding at a rapid pace. The premise of the report that the organization of ICT services and connectivity is best provided by a dedicated organization called the National Research and Education Network (NREN) is based on international best practice and the current plans of the stakeholders in the region. In the following pages, the nature of NRENs and the case for their establishment is outlined and the story of their development in Africa up to their current status is described in detail. Finally, the trends in the use of ICT in higher education and how they might affect the operation of NRENs are discussed as a prelude to a guidance note on how to go about establishing or strengthening an NREN, with recommendations to the government, the private sector, institutions, and development partners. 


\section{Methodology}

The information about NRENs in the report about what they are, the rationale for their existence, the services they offer, the challenges they encounter, and their vision of the future comes from a long partnership between the knowledge programs of the World Bank and NRENs and their regional associations around the world over the last fifteen years.

The hard data on the status of the NRENs in Africa were gathered through the following means:

- Interviews with NREN managers and regional Research and Education Network (REN) chief executive officers (CEOs) based on two questionnaires regarding (a) the status of an NREN and (b) the usage of an NREN. The status questionnaire was devised using a muchsimplified version of the Common NREN Information Model (CNIM) survey questionnaire that is used in the Trans-European Research and Education Networking Association (TERENA) Compendium (primarily a guide to NRENs of Europe). The CNIM survey is the result of a collaborative effort by the Asia Pacific Advanced Network (APAN), Arab States Research and Education Network (ASREN), CANARIE (NREN of Canada), Internet2 (NREN of the United States), RedCLARA (Latin American REN), GÉANT, UbuntuNet Alliance, and West and Central African Research and Education Network (WACREN). The intention of the CNIM is to document the work of NRENs worldwide.

- Interviews carried out in person at the Internet2 Global Summit in Washington, DC in April 2015 and at the African Internet Summit in Tunis in June 2015, and followed up through email and phone calls.

- Searches through NREN and regional REN websites where they existed, and through PowerPoint presentations from conferences.

- Information from AfricaConnect and EUMEDCONNECT websites and interactions with key players in the projects. 


\section{Introduction, background \& overview}

Across the globe, there has been a fast-growing trend for universities to organize their Internet access and connectivity to each other through centralized organizations called NRENs. Besides connectivity services to members, these organizations create and manage the software and systems that enables global scientific collaboration and access to digital educational resources. Through their international partnerships with other NRENs, and by developing and adopting common standards and protocols, a global highway dedicated to the needs of researchers, educators and students is in place that connects universities, research centers and digital resources in over 120 of the countries of the world (figure 2). Up until recently this excluded SubSaharan Africa (except for South Africa). However, with the recent advent of multiple undersea fiber optic cables reaching African countries (figure 7), and the simultaneous deployment of national fiber infrastructure backbones, many African higher education systems have established NRENs. Many others are planning to follow suit. There are now (as of June 2016) fourteen operating NRENs in SSA and four in North Africa, with advanced planning going on in another twelve countries.

"Over a hundred twenty countries have now established NRENs, that in turn connect to Regional Research and Education Networks (RRENs) in Asia, Europe, Latin America and more recently in Africa and the Caribbean. NRENs are invaluable assets for linking researchers, promoting collaboration and in the implementation of national policy on education and research. I often still argue that in the current world economic context, developing RENs is even more crucial in developing countries, especially Africa, than in developed countries."

- Boubakar Barry, CEO of WACREN, September 2013

\section{What is an NREN?}

The first part of the report explains the nature and role of NRENs and demonstrates that an NREN is much more than just an Internet service provider (ISP). To understand the issue one must be aware that it is the standard practice globally for universities and research centers to connect directly to one another with their own networks which are separate from the commercial or 'commodity' Internet. Therefore, the primary mission of an NREN is to act on behalf of the higher education community in providing advanced information technology (IT) and communications services for connecting academic institutions to each other's networks, and to each other's resources, both nationally and globally. The aim of these connections is to provide access for their members to academic and scientific resources and to support collaboration in teaching, learning, and research. These collaborations require specialized security and identity protocols, or sometimes very high bandwidth on a one-off basis, services that are not generally available or are too expensive through an ISP. These specialized services, often called 'middleware', are what largely justify the existence of an NREN. Yet, while that is its primary purpose, universities still need access to the commodity Internet and in this case the NREN can act as a broker in negotiating deals with ISPS. Then, by delivering REN connectivity and commodity Internet on the one 'pipe' to each member institution the NREN can simplify network management for engineers at the campus level and act as a 'one-stop shop' for connectivity and other services.

\section{The economic case for an NREN}

The economic case for an NREN begins by demonstrating the economies of scale that a consortium of universities can create by acting as a 'buying club' for commodity Internet. Even in its early days, when it may not yet have the capacity to offer sophisticated technical services, an NREN can still be highly valuable to the community by acting as a broker in using the 
purchasing power of a large membership to get deals for its clients. This can include bulk purchase of commodity Internet access from ISPs, software licenses, library subscriptions, cloud computing services, and even computing hardware. But besides aggregating demand, an NREN typically offers a better quality of service by providing dedicated bandwidth to each client, and not sharing the same bandwidth among a number of clients, which is the accepted practice among ISPs. A high 'contention ratio' (a high number sharing) can lead to congestion at busy times. Generally too, an NREN's connection to a client is also a 'symmetrical' one, that is, the same bandwidth for upload as for download, based on the premise that RENs are two-way sharing networks, not just delivery networks. The 1:1 contention ratio and the symmetrical nature of the connections give NRENs an edge in value for money terms.

\section{Governance and Funding}

The models for ownership, management, and funding of NRENs can vary depending on national policy but there is a remarkable similarity around the world. NRENs come about by either a bottom-up effort by IT champions in the universities or by a top-down initiative from the central government. The eventual governance model however is generally a not-for-profit limited company, owned by the member institutions, and with some financial support from government. It is sometimes the case that the NREN is fully owned by the government or is even a part of a government department. Whatever the model, it is universally accepted that it is the demand and input from the member institutions that should guide the policy and management of the network.

With regard to funding it is general practice for operational expenses of NRENs to be covered by fees and service charges from their members, while the government would cover major capital expenses for initial setup and later upgrades (with possible donor support).

\section{NRENS in Africa}

The impetus for the establishment of NRENs in Africa was undoubtedly the arrival of undersea fiber optic cables along the east and west coasts of Africa in the last decade, and the resulting dramatic drop in cost of Internet access. Bandwidth costs have tumbled from typically US\$4,000-6,000 per megabit per second (Mbps) per month to under US\$100 per Mbps per month in some countries as they moved from satellite to fiber optic delivery. These developments were matched by significant efforts by pioneering academics in a few countries who, with the help of the Association of African Universities (AAU) and its REN unit, promoted the idea that African countries needed to establish their own NRENs and have them eventually link together in a continent wide network through an initiative called the Africa Research and Education Network (AfREN).

In the last decade, regional associations of NRENs have been formed to promote the AfREN concept; UbuntuNet Alliance in Eastern and Southern Africa, and WACREN in Western and Central Africa. The European Union (EU) provided the financial means to kick-start this initiative by funding the AfricaConnect project on a cost share basis with partner African countries. The EU had already been funding a program to connect North African NRENs to Europe in a project called EUMEDCONNECT. At the time of that project a group of countries in the Middle East and North Africa formed an association of NRENs called ASREN. The aim of these two projects and similar EU-funded ones in Asia, Central Asia, and Latin America was to enable the emerging NRENs in the regions to establish linkages regionally and to connect to GÉANT, the European Research and Education network backbone, and through it to connect to all other NRENs of the world. The implementing agency of these projects was the UK-based Delivery of Advanced 
Network Technology to Europe (DANTE) organization, the company owned by the NRENs of Europe and managed the GÉANT backbone. ${ }^{1}$

The current development of all African NRENs, including those in North Africa, is now largely planned around this partnership of the three regional associations and their European partners, and timed around the funding cycle of the AfricaConnect project, as phase one has concluded and AfricaConnect2 is well into its first year (began July 2015).

The interest in establishing NRENs has developed in almost all countries in Africa. However, growth is varied with just eighteen networks in operation as of June 2016; four in ASREN, three in WACREN and eleven in the UbuntuNet Alliance. Even within some of those networks the average bandwidth provided to member institutions can be as low as 1-10 Mbps, with an average of 100 Mbps. The map in figure 10 shows the current status of NRENs in Africa as of June 2016 illustrating the stage of development of each country's NREN, ranging from no known action to a developed and operational network with international REN connectivity. Annex 1 lists each country by region and the status of its NREN where one exists.

\section{Vigorous activity but challenges remain}

The emergence of NRENs in Africa shows strong growth with dynamic actors and consortia making progress, but advancement is slow in some countries. The absence of progress in such countries does not necessarily reflect lack of interest among the end user stakeholders. Collaboration among pioneers within the ICT community in universities is common in most countries. As IT professionals engaged in procuring Internet access for their academic colleagues, they already understand the need for an NREN and the advanced services it can provide over and above simple Internet access. Their challenge is to persuade their institutional leadership and, in turn, their governments, of the need for a dedicated network that can respond to the special needs of researchers, teachers, and students, and that this is a far more complex issue than simply providing Internet access. Possibly the greatest challenge faced by these pioneers and champions is the lack of awareness among decision makers of how the Internet works and what value added an NREN can bring to higher education. While funding is also a challenge the primary roadblock to further development in some countries is the awareness gap, and that can only be overcome by advocacy.

The awareness gap may also extend to a lack of knowledge of just how much the IT revolution has affected day-to-day teaching and learning in OECD countries, where the first port of call when seeking the latest knowledge, especially in the STEM ${ }^{2}$ subjects, is the Internet, not the textbook. This applies to both teachers, who are updating their subject knowledge and their teaching methodology, and to students who are already digital natives. The contribution that resources accessible through the Internet can make to improving the quality of teaching and skills development in African schools and colleges needs to be demonstrated to educators and to decision makers in government.

Added challenges in some African countries include the late arrival of fiber infrastructure, the conservative attitudes within incumbent Telcos, and, where telecoms are deregulated, the very aggressive competition from ISPs who see NRENs as poaching on their customer base. In other cases preparatory work is well advanced but an injection of funding is required to realize the plans.

\footnotetext{
${ }^{1}$ DANTE has since merged with TERENA, the association of European NRENs, into one

organization called simply GÉANT, which is owned by the NRENs of Europe.

2 STEM: Science, Technology, Engineering and Mathematics.
} 
The Role and Status of National Research and Education Networks (NRENs) in Africa 


\section{The Emergence of NRENs}

\section{The Nature and Role of NRENs}

Much of the early development of the Internet ${ }^{3}$ was carried out by university-based researchers in the United States and Europe over twenty-five years ago. As the Internet went mainstream in the early nineties with the establishment of the World Wide Web, the research and education communities found that this emerging commercial Internet, with its commodity services, was not serving their purpose for large data transfers or for the specialized needs required by academics in scientific and medical research. The community's response was to continue to build its own private networks, on a country-by-country basis, with greater and greater bandwidth, more direct communication between nodes, and with their own authentication and identity protocols: a kind of private Internet. These networks and the organizations that operate them are called National Research and Education Networks (NRENs), with names like Internet2 in the United States, RENATER in France, Rede Nacional de Ensino e Pesquisa (RNP) in Brazil, and CERNET in China. The national networks are connected to regional backbones, such as GÉANT in Europe, RedCLARA in Latin America, or more recently, the UbuntuNet Alliance network in Eastern and Southern Africa. As a collaborative global community, each NREN typically offers peering arrangements with its partners to support one another's traffic at no charge. This has resulted in a global Research and Education Network (REN) community that universities can connect to through their local NREN.

An NREN is both (a) a physical high-performance communications network operated for and by the education and research community of a country and (b) the organization that operates that network, constituted either as a consortium of members, a dedicated agency, a company, an NGO, or other type of body.

Rarely will an NREN lay and own the physical cable infrastructure of its network, except maybe for last mile connectivity to each of its member organizations. More typically capacity is leased from network owners such as Telcos or power companies and the traffic itself is managed and monitored by the NREN. In countries where telecom fiber infrastructure is only being established, such as those in Africa, an NREN may simply be a consortium of universities that organize themselves as a 'buying club' to aggregate demand and to get a better price from Internet service providers (ISPs).

The primary role of an NREN is to provide advanced information and communication technology (ICT) services to its members and its most visible service is to operate the national backbone that connects a country's university campus networks to each other and to other research and education networks globally. It may also offer a gateway to commodity Internet services or act as a broker for its members in procuring commodity bandwidth from ISPs. It runs its own Network Operations Center (NOC) to manage all traffic on the network, and it can provide technical support services and training to all of its members.

\footnotetext{
${ }^{3}$ Besides the work of the U.S. Defense Department that set up DARPAnet.
} 


\section{Box 1. Beyond Connectivity - Other Services Provided by an NREN} An NREN can offer a whole range of other ICT services depending on its remit and the needs of its members. As many specialized services become commoditized however, some of these services can be contracted out to commercial operators. The services include:

- Security: spam screening, anti-spoofing measures, and so on

- An e-mail service for all members' constituents, faculty, and students

- Videoconferencing bridging, recording, streaming

- Hosting a higher education management information system (HEMIS)

- Managing learning management systems (LMSs) such as Moodle or Blackboard

- Access to Digital Library sources and electronic journals

- Web hosting and data storage and archives if required

- Multimedia content repository

- Connect e-science resources such as telescopes, sensor networks, accelerators, supercomputers

- Bandwidth on demand

- Computing power

- Mirroring of content from outside the NREN network

- Cloud services

- Campus networking advisory services

- Capacity-building workshops

Middleware services

- Authentication and Authorization Infrastructure:

o eduroam, eduGAIN, Shibboleth, single sign-on (SSO) federated access services

o e-science gateways

- Grid computing middleware

- Dedicated point-to-point internet protocol (IP) circuits for special applications

\section{Who Uses NRENs and For What?}

At its most basic an NREN can offer more reliable bandwidth at less cost but it offers much more than that. Through its user identity management systems an NREN is critical for (a) participation in international collaborative research and to connect faculty and students to the global academic community; (b) access to digital resources and databases, costly instrumentation (super computers, telescopes, electron microscopes, and so on), high definition video; and (c) exchange of big data files, and so on. A more advanced NREN can also provide a springboard for innovation in a country, supporting experiments in networking and new discoveries and services in IT that their members are exploring.

\section{Research collaborators/collaborations that NRENs support}

- The Large Hadron Collider (LHC) at Conseil Européen pour la Recherche Nucléaire 
(CERN) in Switzerland (where the World Wide Web was invented) collaborates with physicists from all over the globe who access huge data sets as part of the Large Hadron Collider experiments, connecting generally through their local NREN.

- Access to and real-time remote manipulation of telescopes high in the Andes and other locations by astronomers in their home institutions.

- Access to 'big data' sources such as human genome data sets, astronomical survey data, and so on.

- Extending astronomical reach. One of the most powerful techniques in astronomy is Very Long Baseline Interferometry (VLBI). This technique uses multiple radio telescopes to simultaneously observe the same region of the sky. Data from each telescope is then correlated centrally, simulating a single, giant telescope, to provide high-resolution images. SURFNET (NREN of the Netherlands) and GÉANT provide connectivity to one such program. ${ }^{4}$

- Cost-efficient short-term leasing of time on Supercomputers for large-scale calculations.

- Access to e-labs such as electron microscopes that the home institution cannot afford (MIT's e-Lab)

- Medical research into tropical diseases by research institutions in non-tropical countries (Wellcome Trust UK in Uganda through RENU). Also needed, but not available yet for the U.S. National Institutes of Health $(\mathrm{NIH})$ research collaborations with the Ministry of Health in Mali (MaliREN at the early planning stage).

- Grid computing whereby using the spare capacity of hundreds of PCs distributed in a country simulates a supercomputer.

\section{Examples of NREN support for teaching and learning}

- Remote campus through telepresence (a high-definition large-screen version of videoconference that is more immersive than traditional systems). Internet2 connecting Georgetown University to Qatar, New York University to Abu Dhabi and Shanghai, Dartmouth College to Chinese sites

- Indian Institutes of Technology in India expanding reach with the 'Country-wide Classroom' on the National Knowledge Network (NKN) of India

- Providing high-speed access for multiple simultaneous users to e-learning courses such as Massive Open Online Courses (MOOCs), Khan Academy, and so on.

- Pre-authenticated and authorized access to e-journals globally

- Access to video-based streaming lectures from world experts (mainly through YouTube)

- Outreach to other levels of education

${ }^{4} \mathrm{http} / / /$ ec.europa.eu/research/infocentre/article_en.cfm?id=/research/headlines/news/article_07_11

_26_en.html\&item=\&artid= 


\section{Other uses and clients}

The use of NREN is not confined to higher education and research institutions. A number of NRENs are reviewing the terms of their Acceptable Use Policies (AUPs) to broaden them to include other knowledge institutions and public sector agencies. In the education sphere the client base of NRENs is expanding to include libraries, museums, colleges and schools. In the public sector too, government networks and health services are accessing the NRENs and their uses include:

- The collection of weather data for meteorology services (VinaREN in Vietnam)

- Telemedicine applications for remote diagnostics

- Demonstrations of new surgical techniques using ultra-high-definition video (4K and 8K video) in Brazil $^{5}$ and Japan ${ }^{6}$ and linking to other countries through regional RENs (by RNP the Brazilian NREN)

- The monitoring of the effects of climate change on melting glaciers and the risk of flooding in Kyrgyzstan with the Central Asian Research and Education Network, (CAREN) and GÉANT linking institutions in Kyrgyzstan, Austrian, Sweden, and Germany. ${ }^{7}$

- Typhoon watch - the German weather service Deutscher Wetterdienst (DWD) exchanging masses of real-time data with its Philippines counterpart, Philippine Atmospheric, Geophysical and Astronomical Services Administration (PAGASA) for early warning of typhoons-through GÉANT, TEIN4 and PREGINET ${ }^{8}$

- Cultural collaboration in the performing arts-musical performances and dance, examples can be seen in Internet2, GÉANT, and Asia Pacific Advanced Network (APAN) ${ }^{9}$

- Connecting community anchor institutions, including public libraries, schools, community colleges, research parks, and public safety and health care institutions with advanced broadband capabilities. The United States Unified Community Anchor Network (U.S. UCAN) is a new national project dedicated implemented by Internet2 and other partners ${ }^{10}$

- Providing optical network connectivity to government departments; RENATER (NREN of France) has been mandated by the French government to provide such services

- Connecting Schools: HEAnet, Ireland's NREN, has connected all Irish secondary schools to its backbone at 100 megabits per second (Mbps) symmetrical (same bandwidth up as down) at a 1:1 contention ratio (the bandwidth is dedicated and not shared with other schools) ${ }^{11}$

- Kenya Education Network Trust (KENET), NREN of Kenya, is connecting all schools in Nairobi to its network and providing an educational portal ${ }^{12}$

\footnotetext{
5 University Telemedicine Network on RNP: http://rute.rnp.br

6 http://cdn.intechopen.com/pdfs-wm/14274.pdf

7 http://www.geant.net/Resources/Media_Library/Documents/caren_glacier_web.pdf

8 http://www.geant.net/Users/Environment/Pages/PAGASA.aspx

9 http://www.internet2.edu/presentations/fall11/20111002-Allocchio-IntlArts-update.pdf

10 Final Report of the U.S. UCAN Task Force on Community Anchor Network Economic Models

July 31, 2011

http://www.internet2.edu/media/medialibrary/2013/09/09/UCAN_TF_final report.pdf

11 Schools 100Mbit/s Project: http://www. heanet.ie/schools/schools-100-mbits-project

12 KENET Schools Connectivity Project: https://www.kenet.or.ke/node/180
} 


\section{Ownership and Governance of NRENs}

There are many models of NREN governance around the world. A common approach is to establish an NREN as a not-for-profit limited company, or trust, owned by the members with only limited government representation, if any, on the board. While a government ministry, be it Education, Higher Education, Science and Technology, or Communications, may have a major say in how an NREN operates and is funded, it is accepted that users and their needs drive the operation. It is regarded as vital that the academic community is strongly represented on the governing board of the NREN, for without stakeholder ownership an NREN can flounder. This independence helps to attract and retain talented staff as higher salaries can be paid if the pay structure was not tied to public sector pay scales. One of the competitive advantages that mature NRENs boast of is the high caliber and expertise of their staff. In a developing economy with a burgeoning private sector, especially in the tech industries, the competition for skilled personnel is intense and an NREN needs to be an equal player among employers in this environment.

There are successful exceptions to this model, notably in India and in Pakistan. While the NRENs in these countries are structured quite differently from one another one common aspect is that they are government owned and government run. In Pakistan the NREN, known as Pakistan Education and Research Network (PERN), is operated from within the Higher Education Commission (HEC), and in India the NREN equivalent is the National Knowledge Network (NKN) operated by the National Informatics Centre, a division of the Ministry of Communications. However, most NRENs are operated as independent organizations but with a reporting function to, or owned by, a ministry or similar body, most appropriately, but not always, the Ministry of Higher Education.

\section{Funding and Business Models}

There are various funding models for NRENs, but generally it is a combination of government subvention, membership fees, and user service fees. In a country with mostly public universities this means that ultimately the government is the source of funding for the NREN, even if indirectly. The NRENs of Europe show a range of national options as in the table in figure 1 from the Trans-European Research and Education Networking Association (TERENA) Aspire study. ${ }^{13}$ This can be a useful guide to African countries as many NRENs in Europe, especially in the east, are only recently emerging.

When an NREN is being established or when it is upgrading its infrastructure a case can generally be made for the 'public good' nature of its services, and as a consequence its network capacity does not necessarily have to be acquired at commercial rates. There are avenues to explore in getting subsidized infrastructure. For instance, telecom regulators in many countries impose a tax on private operators to create a fund to subsidize the provision of services to locations or populations that would not be commercially viable. These funds are called Universal Service Funds or Universal Access Funds (UAFs) and they have been used in some countries to part-fund the establishment of NRENs. Another form of subsidy is the donation of fiber to an NREN by a fiber owner such as a utility company. SudREN, the NREN of Sudan, has benefited from its country's Universal Service Fund, and ZAMREN in Zambia has received donations of fiber from the power company to build its national backbone network, and from UAFs to provide

13 The Future Roles of NRENs: ASPIRE - A Study on the Prospects of the Internet for Research and Education. TERENA September 2012. https://www.terena.org/activities/aspire/docs/ASPIREfuture-of-nrens.pdf. 
local, or 'last mile' connectivity to the universities. In an ITU study in $2013^{14}$ Universal Service Funds or similar schemes were identified as being available in a dozen African countries: Burkina Faso, Ghana, Lesotho, Mali, Morocco, Mozambique, Nigeria, Rwanda, South Africa, Sudan, Zambia, and Zimbabwe.

Ongoing financial sustainability needs to be planned for from day one of the establishment of an NREN, even if a government or donor provides startup funds. Most NRENs require funding from a combination of government subvention and membership and services fees, the actual ratio being determined by policy. A rule of thumb for many NRENs is for operating costs to be funded by fees and capital expenditure by government grants. In discussing the sustainability of new NRENs in Africa it should be remembered that universities have already been paying high prices for small amounts of bandwidth. The transition from satellite-based bandwidth to terrestrial fiber that is happening currently in Africa is resulting in a significant reduction in cost per megabit per month and therefore existing university budgets for bandwidth can remain relatively neutral by a switch from paying the high cost of satellite connectivity for low bandwidth to paying the same amount to the NREN for much greater bandwidth. For example, the same budget of US $\$ 8,000$ per month for $2 \mathrm{Mbps}$ by satellite can result in up to $80 \mathrm{Mbps}$ from an NREN's fiber connection.

figure 1. Funding Models of NRENs in the GÉANT Area (courtesy: GÉANT)

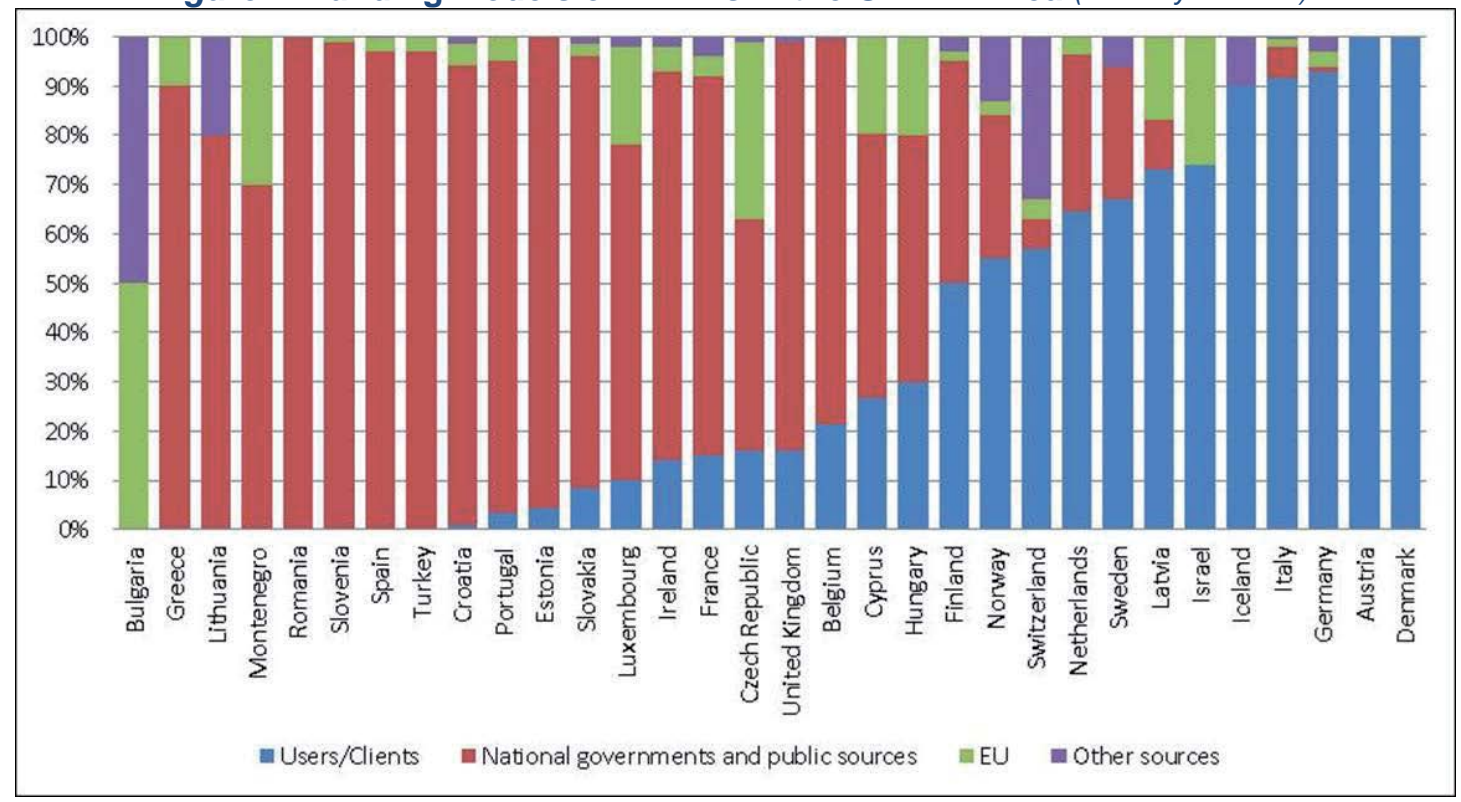

\section{Options for Managing Cost/Increasing Affordability}

The extent of actual technical management of a network varies among NRENs, but advanced NRENs are now typically leasing 'dark fiber' capacity on the networks of owners such as Telcos, power companies, or railways, and doing everything else that an operator would do, with their own terminal equipment, routers, switches, servers, and so on. Dark fiber refers to the individual strands or cores of fiber optic cable that remain un-terminated and unlit, ready for an operator to do so. A number of cores can be bought or leased as pairs on a single contract for the life of the fiber, generally about 20 years, on the basis of what is called an Indefeasible Right of Use (IRU). An initial down payment would be followed by annual maintenance charges to the owner of the cable and the NREN would be responsible for managing the traffic on its part of the cable. If the 
fiber network is owned by or originally funded by a government or public agency like a power grid company then it may be possible to get 'free' fiber and to pay just for the recurrent maintenance cost, as was the case in Zambia (and in Ireland). This scenario does presume a certain engineering capacity on the part of the NREN, but it could have the advantage, especially for donor-funded projects with a short duration, that it would cover much of the upfront cost of the network infrastructure, and bandwidth could be expanded in the future without leasing more infrastructure (it is done by multiplexing more wavelengths on the same fiber). It is better to use a loan to acquire a long-term asset than to cover monthly recurring costs. There are examples of this practice globally, such as in Bangladesh and its NREN, BdREN. ${ }^{15}$

Another use of the IRU is to lease an individual wavelength or 'lambda' (the Greek letter $\lambda$ ). A lambda is the term used in telecoms to describe individual wavelengths or 'colors' being transmitted down a fiber optic cable. This is much less expensive than leasing a full core of fiber as a lambda is just one of 16 wavelengths (and now, with advances in technology, up to 80 or 100 wavelengths) in a single core. This approach may be more suited to a start-up NREN with few financial resources.

Finally, for NRENs with low technical capacity, there is the option of simply purchasing bandwidth and operating the NREN as a Virtual Private Network (VPN). In the longer term, this could prove expensive as demand rises and more bandwidth has to be purchased at market rates. However, the initial investment is relatively low.

\section{Status of NREN Development Globally}

Virtually every advanced, and many emerging economies, now organize their education and research connectivity through NRENs. The data in the map in figure 2 is based on the TERENA Compendium $2014^{16}$ and it has been updated and modified through consultations with regional REN managers. Countries with operational NRENs are in marked in green, those in advanced stages of planning an NREN are in yellow, and those with little or no plans are in grey. While progress has been made in Africa since the TERENA version was published there are still only 18 countries on the continent of Africa with operating NRENs. The good news is that virtually all other countries on the continent are planning to establish one, although the stages of development vary widely. 
figure 1. Countries with Operational NRENs or In Advanced Planning for One

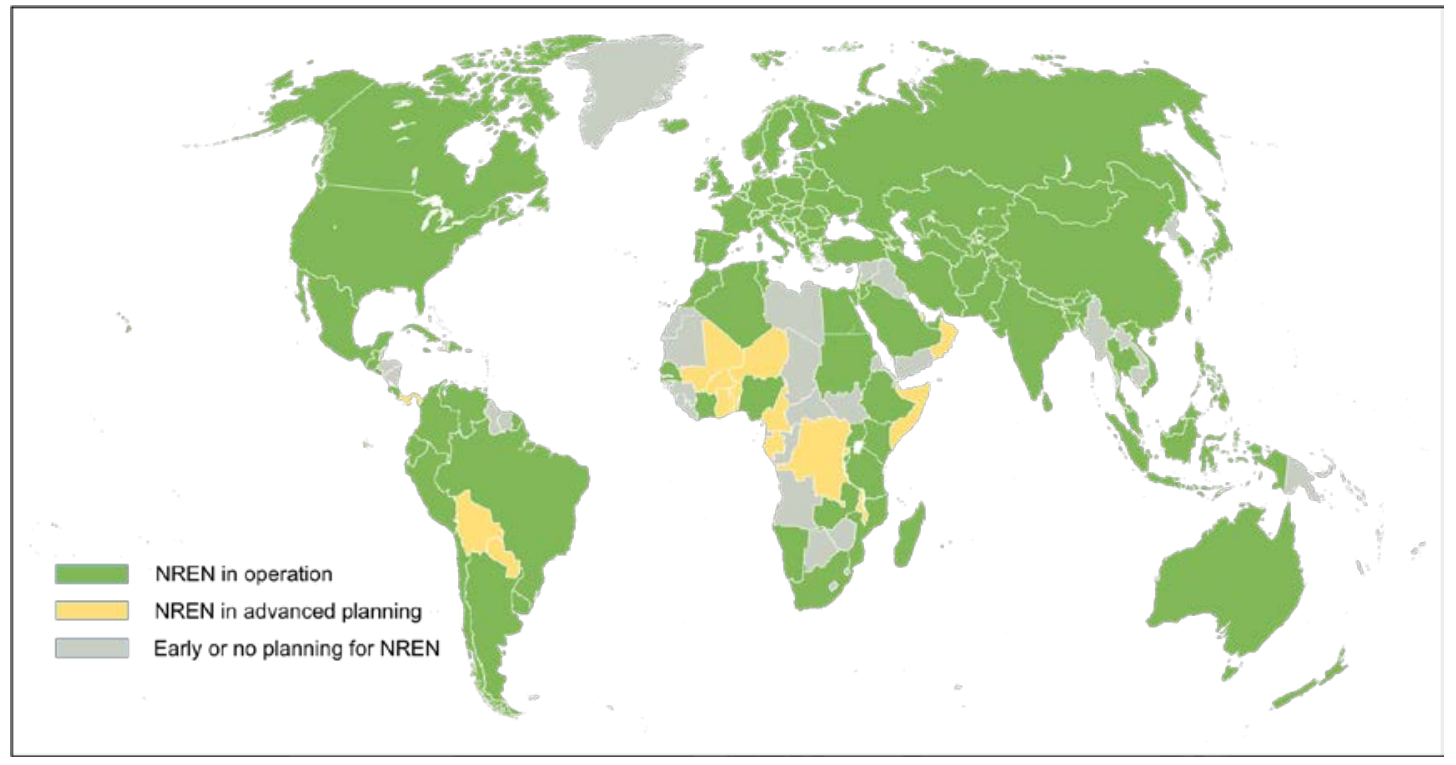

\section{Regional Associations of NRENs}

While NRENs are what their name suggests, that is, national organizations, with their own governance and business models reflecting their national identities, their roles in providing global connectivity to their members propel them towards ever more closer collaboration and coordination with their regional and global partners. While there are global fora for NREN CEOs, the clustering of NRENs is currently at the regional level. These regional clusters may be either actual physical networks or associations of NRENs or both, and they include, in alphabetical order: APAN, the Asia-Pacific Advanced Network, ${ }^{17}$ ASREN, the Arab States Research and Education Network, CAREN, the Central Asian Research and Education Network, ${ }^{18}$ CKLN, the Caribbean Knowledge and Learning Network and its network C@ribnet, ${ }^{19}$ GÉANT and its network GÉANT, the European backbone of 40 European and neighboring NRENs, ${ }^{20}$ RedCLARA, the backbone connecting the NRENs of Latin American countries, ${ }^{21}$ UbuntuNet Alliance, ${ }^{22}$ the regional REN of Eastern and Southern Africa, and WACREN, the West and Central African Research and Education Network ${ }^{23}$ (currently an association only but planning to be a regional network in the coming years). One could include Internet ${ }^{24}$ in the United States in this list as it functions to a certain extent like a regional REN because its main physical presence is its backbone, which connects all of the state networks of the United States. As a national organization it is also regarded as an NREN.

The largest regional organization and network globally is undoubtedly the GÉANT network, linking as it does over forty countries within its own backbone. It would be useful to clarify here

\footnotetext{
17 http://www.apan.net 18 http://www.caren-noc.org

19 http://www.ckln.org

20 http://www.geant.org

21 https://www.redclara.net

22 http://www.ubuntunet.net

23 http://www.wacren.net

${ }^{24}$ http://www.internet2.edu
} 
the relationship between it and the DANTE agency and the TERENA Association since the latter two have recently merged into one organization, called simply GÉANT. TERENA was first formed in 1986 as the Association of European NRENs under the name of Réseaux Associés pour la Recherche Européenne (RARE) and changed its name to TERENA in October 1994. DANTE was formed in 1993 in Cambridge, United Kingdom as a not-for-profit limited liability company by the NRENs of Europe to implement the interconnection of national NRENs to each other with a high-speed backbone, which came to be called GÉANT in 2000. DANTE was also responsible for the interregional projects, the majority of them funded by the EU's aid program, which includes TEIN, EUMEDCONNECT, Alice (out of which RedClara was formed), CAREN, and AfricaConnect.

Simply put, up to October 2014 there were (a) GÉANT the European backbone network connecting the national RENs to each other and to other regional networks; (b) DANTE the agency that implemented GÉANT; and (c) TERENA, the association of European NRENs. With the merger of DANTE and TERENA in 2014 the new organization was called the GÉANT Association, which was changed to simply GÉANT ${ }^{25}$ in May 2015.

Internet2 in the United States has a number of connections to regional networks in Asia, Latin America, and Europe. International Networks at Indiana University (IN@IU), ${ }^{26}$ funded largely by the NSF, manages some of these links through the TransPAC and ACE projects in partnership with Internet2, APAN, and GÉANT. Other collaborations in research networking includes the GLORIAD network (The Global Ring Network for Advanced Applications), originally a joint U.S.Russian initiative to link their respective scientists and academies. China joined later, which saw the completion of a ring network around the northern hemisphere, and now there are over 15 countries connected, including Egypt (see figure 6).

To illustrate the level of development of international partnerships between national RENs and research centers the following maps, provided courtesy of the relevant organizations, are selfexplanatory.

\footnotetext{
${ }^{25}$ http://www.geant.org

${ }^{26}$ http://internationalnetworking.iu.edu/about/index.html
} 
figure 2. Topology of the NREN Interconnections in APAN (courtesy: APAN)

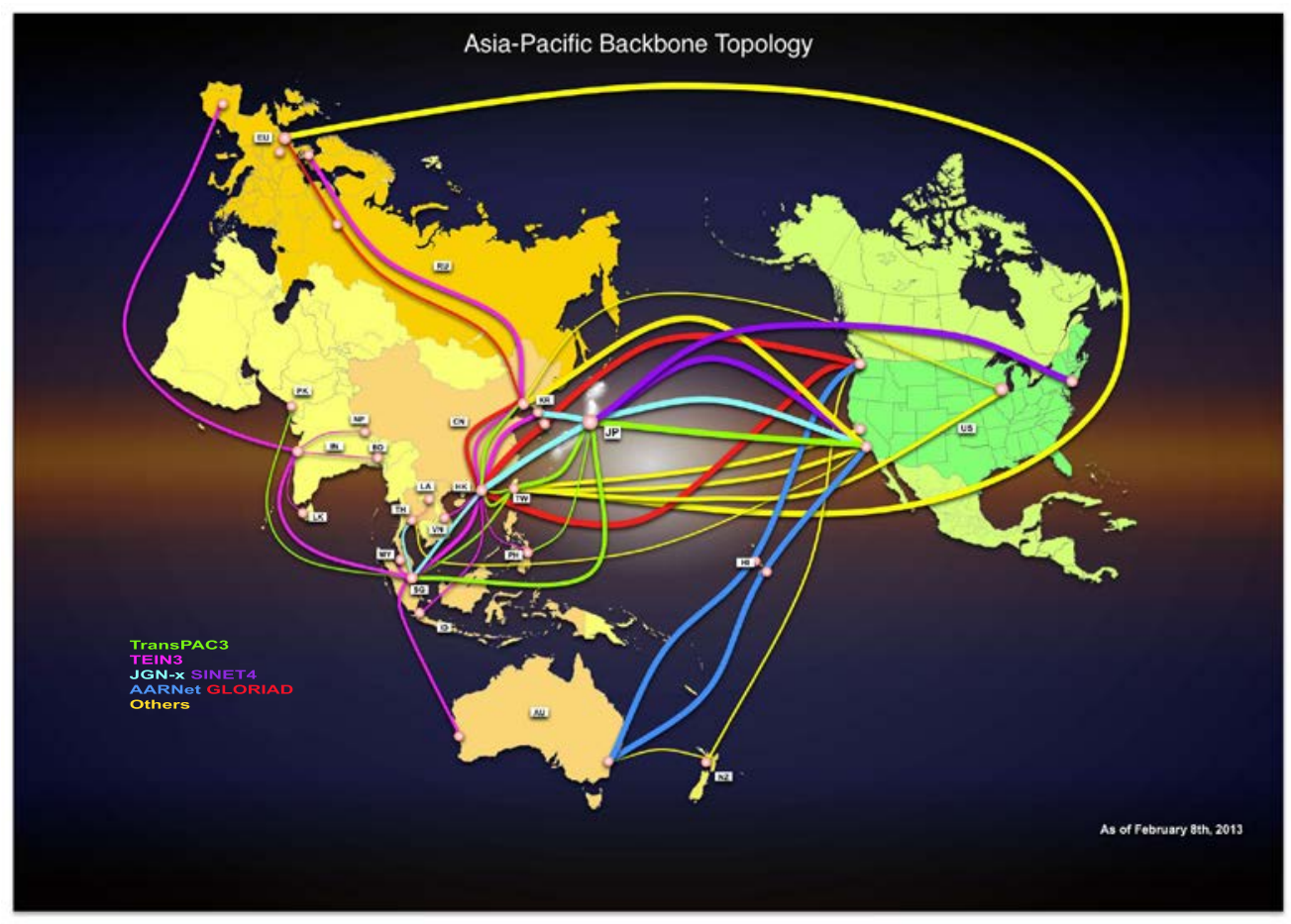

figure 3. Inter-regional Links between GÉANT and the Rest of the World (courtesy: GÉANT)

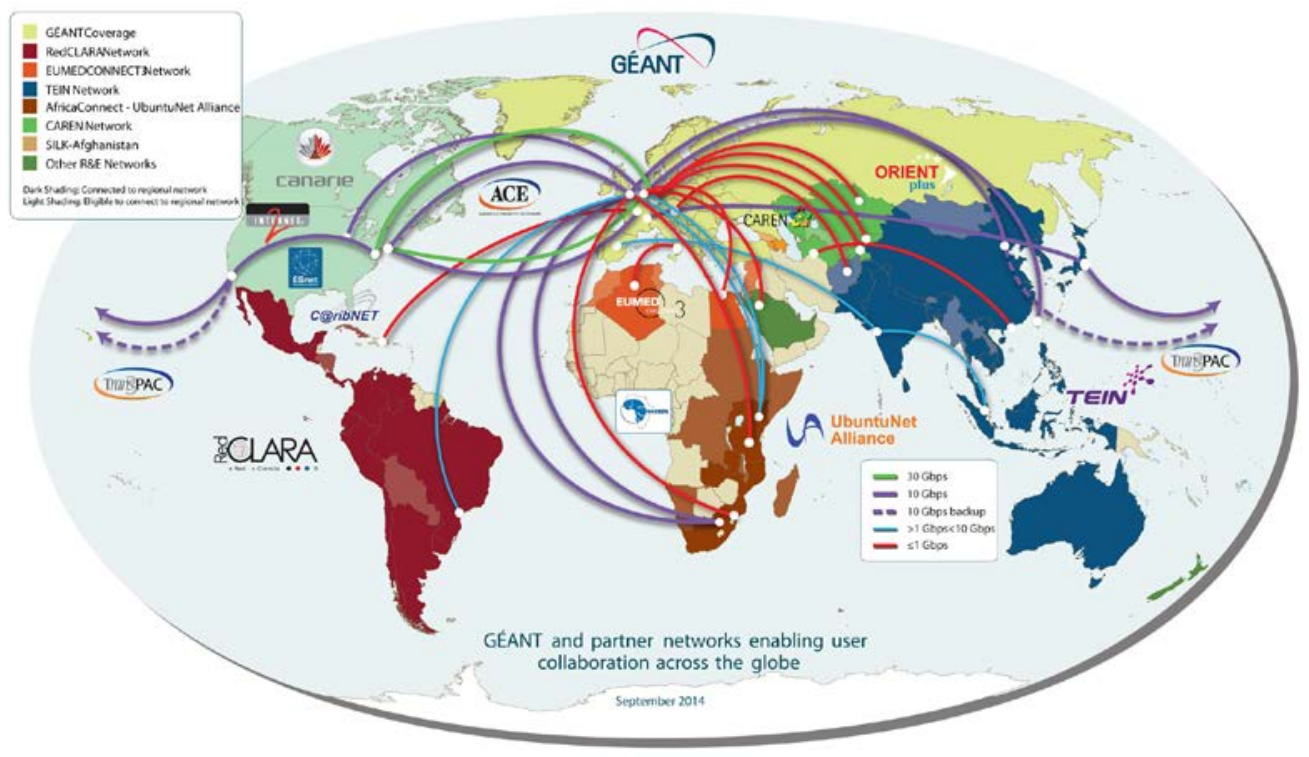


figure 4. RedClara Topology Courtesy of RedClara (courtesy: RedCLARA)

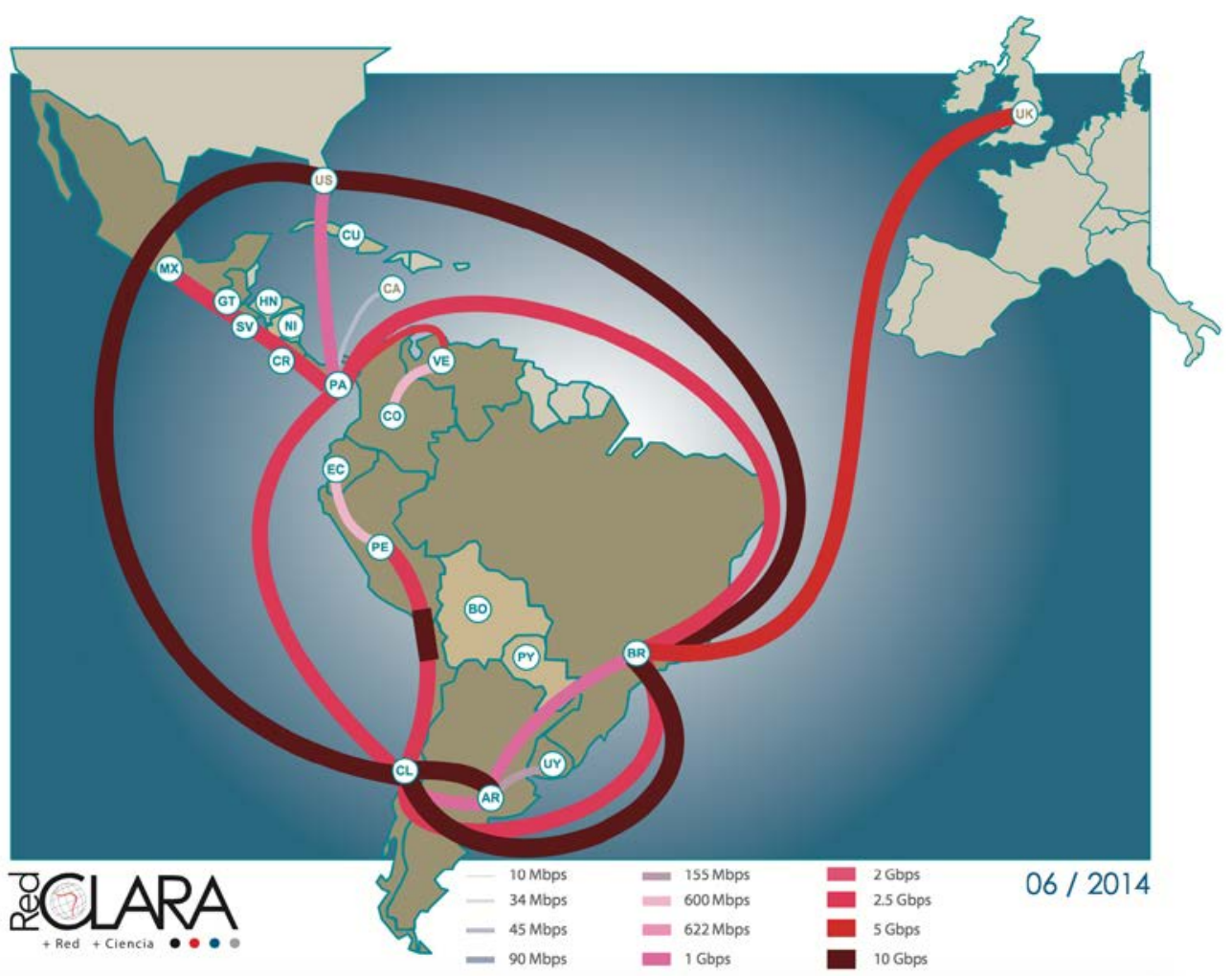

figure 5. GLORIAD Science and Education Network (courtesy: GLORIAD)

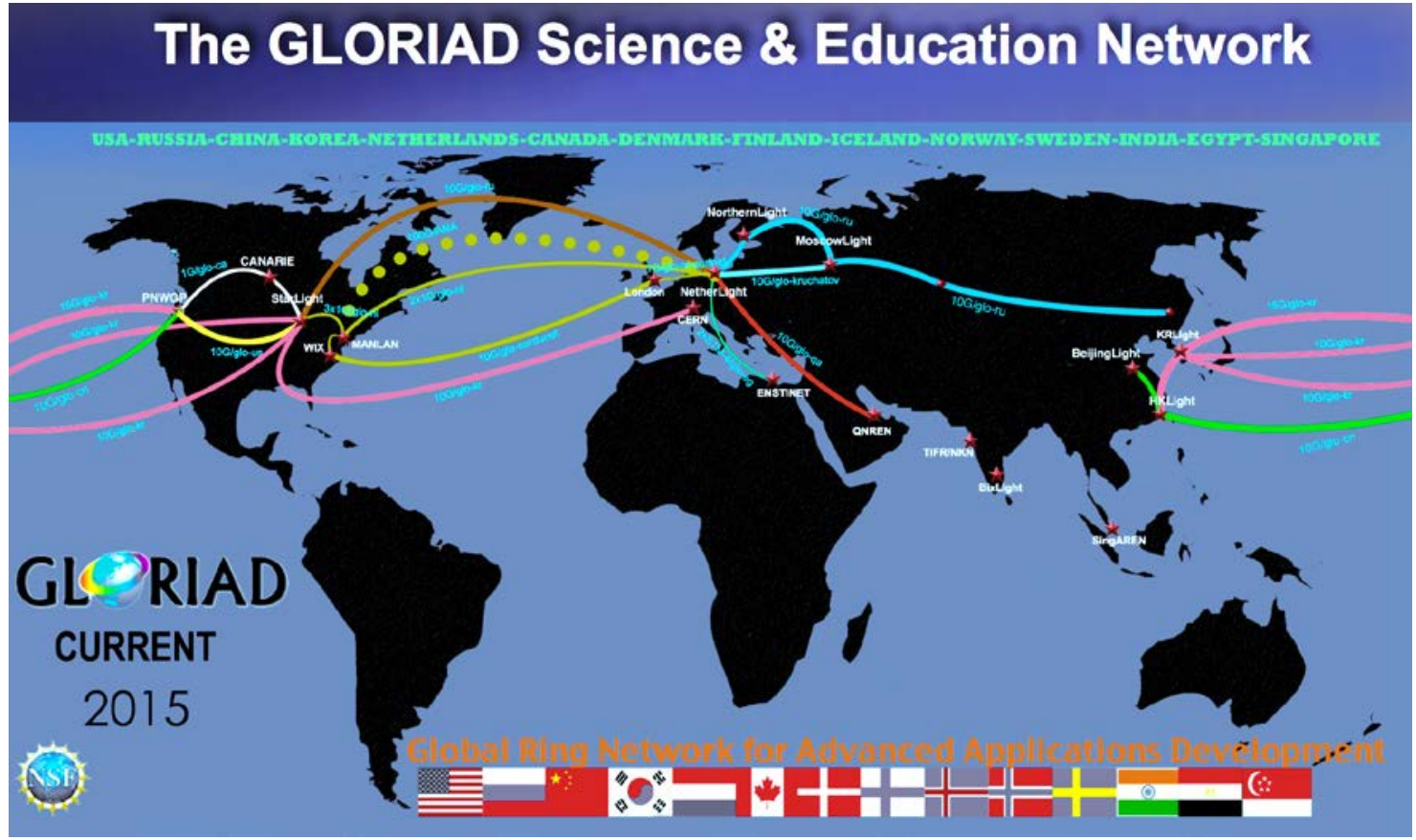


The Role and Status of National Research and Education Networks (NRENs) in Africa 


\section{3: The Case for Establishing an NREN}

The question is often asked, "why establish an NREN when we have many ISPs in the country ready to provide Internet connectivity to the universities?" Over 25 years ago, when NRENs in Europe and the United States were evolving (although not yet called NRENs), and when telephone companies did not see data as their primary product, a time before ISPs existed, this question did not arise. Now that Internet services are standardized commodities and telecom services are largely deregulated this question is foremost in the minds of policymakers and funders, especially in the case of emerging NRENs in Africa. The advocates of NRENs in Africa have a difficult task to persuade the funders of the validity of their case because the question is posed simply on the basis of the price of bandwidth. An economic case can certainly be made for NRENs on this basis, and it is made below, but the true value of having an NREN is not about price of bandwidth but about services, especially the higher level services that are required by, and specific to, the needs of academia, and that ISPs do not provide. The dilemma for the nascent NRENs is that while they are in their early stages of development they do not have the technical skill sets to deliver those services-a classic 'chicken and egg' situation. It would be important that university leadership and government decision makers understand the issues involved here and for them to see beyond the 'bandwidth provider' role of their emerging NREN. The following sections explain the economic case for an NREN and provide a description of some of the advanced services that a mature NREN can offer, illustrating the wisdom of establishing one. Further information and resources are available on the portal 'The Case for NRENs' which is hosted by GÉANT and which was compiled by a panel of veteran research and education networking professionals and representatives of the regional network organizations from outside Europe. ${ }^{27}$

\section{The Economic Case for an NREN: Aggregation of Demand and Value for Money}

In the competitive marketplace of Internet services comparisons are made on the price per megabit per second (Mbps) per month. However, without knowing how telecom connectivity is priced and without an understanding of how these networks operate, making purchasing decisions based purely on price per Mbps per month can be rather shortsighted. ISPs are ready to exploit this situation and NRENs find it difficult to compete on this simplistic base. Two areas of telecoms need to be understood to make an informed decision: (a) the savings to be made by aggregating demand and (b) how network management policies affect performance and value for money.

\section{Aggregating demand}

Transmission systems aggregate traffic into large blocs at the gigabit per second level and the providers sell capacity in smaller chunks of 10 or $100 \mathrm{Mbps}$. The price per Mbps is significantly higher if capacity is bought in these smaller chunks. A consortium of universities, therefore, can make large savings if they form a 'buying club' and purchase large chunks of capacity in bloc to be shared among members of the club. The best way to organize this club and the management of the resulting capacity is through an NREN.

27 The Case for NRENS, 2015. GÉANT. www.thecasefornrens.org 


\section{Value for money and performance of the network}

Comparing the value of competing service providers simply on their advertised price per megabit per second per month can be misleading because it does not describe the delivery model of that megabit. One needs to ask if that megabit is shared or not, and if it refers to downloading only and not to uploading as well. The issue has to do with what is called the 'contention ratio' of the service and whether the connection is 'symmetrical' or not. It is common practice by providers that a given amount of bandwidth is shared among a number of customers, based on the hope that not all of them will use it at the same time. The size of the pool of customers sharing the same bandwidth is called the contention ratio, for example, 50:1 means fifty customers sharing the same bandwidth, and the higher the ratio the poorer the performance of the network. At busy times of the day the number of users rises and the actual available bandwidth per customer goes down, resulting in what is called 'packet loss' and 'jitter', a real problem for audio or video traffic. In addition, most commercial providers offer a much higher download speed than an upload speed, for example, an advertised 8 Mbps service may offer 8 megabits download but only a 0.5 megabit upload. The service is not symmetrical. This will impinge on quality, and especially for videoconferencing where upload demand is the same as download demand.

NRENs typically offer a 1:1 contention ratio, so their megabits per second are a dedicated allocation to a customer and links directly into the global research and education networks. The bandwidth provided is also symmetrical (unless it is by satellite), giving the same upload and download speeds, a requirement for two-way communications using video. Therefore, competing on the price per Mbps per month is not a like-for-like competition and the NREN's performance and the access it provides to other RENs offers much greater value and predictability.

\section{Risks of the Buying Club model}

Moving beyond the price of bandwidth the case for NRENs will be based on the services they provide rather than on what they charge for bandwidth. TENET, the NREN of South Africa sums this up well, highlighting the risk of the 'buying club' model:

"TENET's focus has been on the challenge of securing ever more Internet bandwidth for the beneficiary institutions at ever better unit prices. However, the substantive deregulation of telecommunications in South Africa means that bandwidth will become a commodity and the unique value that TENET and SANReN can offer in future will depend less and less on securing compelling price advantages and rather on the provision of specialized, targeted value-added services that universities and research institutions require. Such services include, for example, the use of very high-speed but temporary, un-routed point-to-point circuits ('light paths') for moving very large datasets to or from anywhere in the world; high-quality videoconferencing; and the establishment of trust federations in which many institutions agree to provide their staff and students with access to each other's electronic resources, including, but not limited to, library and computing resources, using federated authentication and authorization schemes." 28

The potential conflict with the private sector could be dampened by the realization that the existence of an NREN creates new market opportunities for commercial IT providers. Acting as a broker of services for their members an NREN can bring buying power to its partnerships and contracts with the telecommunication companies, ISPs, and other service providers for example, for mobile services to students (discounts, and so on), or providing commodity Internet services, email services, or cloud storage, and so on. Some advanced NRENs and universities are dropping some of their own applications and using Google mail services, Google Apps for

${ }^{28}$ The Service Development Challenge: http://www.tenet.ac.za/about/about-tenet-1 
Education, and Amazon cloud services among others. E-learning software providers such as Blackboard and Moodle are not only providing the software but also in many cases hosting the content of universities' LMS. ISPs should also remember that every student at university will be accustomed to high-speed Internet access and will be seeking a similar service in the marketplace on graduation.

Competitive pricing from the private sector is also not the only thing that threatens the NREN's sustainability. An NREN will only be successful if there is a large take-up of its services by the academic community. There is a critical mass of membership that is essential if the NREN is to succeed and be financially sustainable. Therefore, on the one hand, an NREN needs to be efficient and responsive to user needs and, on the other, it needs official government support, protection and promotion, even if that support is 'hands-off'.

"In its simplest form the new NREN might simply be a consortium to leverage collective buying power. Such consortia have considerable potential to develop into more mature NREN structures, but they are also at considerable risk: they are cordially disliked by providers, who are not always unwilling to take measures to break the underlying collaboration (such as loss-leader offers, or attempts to cherry-pick the major participants.) It is critically important in such contexts for the executive leadership of participating institutions to sustain the willingness to collaborate and to focus on the achievement of longterm benefit, even if this involves the loss of short-term gains. The pure purchasing consortium remains vulnerable as long as its only benefit is price, and the realization of additional benefits should be an early objective."

- Duncan Greaves, CEO, TENET, South Africa

\section{Advanced Services - Supporting Collaboration and Facilitating Access}

The services that an advanced NREN offers that differentiate it from an ISP are the portfolio of services that are broadly called 'middleware' services. ${ }^{29}$ It is here that the real added value of an NREN can be demonstrated. The most visible of these services is a portfolio of services called Authentication and Authorization Infrastructures (AAIs). The collaboration over networks that exists between educational institutions is based on mutual trust, but not naïve trust. Trust is about the identity of users on a network (that they are who they say they are) and the acceptance of that identity by other networks and service providers. Of course, trust needs to be mutual; service providers have to demonstrate that they respect the identity and privacy of users too. It starts with the authentication of the identity of the individual users, be they professors or students, when they register for an account in their university, and their authorization to access internal networks, library databases, and other digital resources in the home institution. As research and education has become globalized, with partnerships and resource sharing growing exponentially, it would be a drag on collaboration if the authentication had to be repeated for every access service offered by other institutions and providers. This is where NRENs can provide an essential role unmatched by a local ISP. By building agreed AAIs with partner NRENs and service providers throughout the world, the local NREN can ease the way for its home clients to integrate with the global academic community. The standards for

${ }^{29}$ Middleware, as its name implies, is software that lies between software applications and

operating systems on a network that allows them to talk to each other - a kind of software 'glue' 
security and collaboration within the research and education community are negotiated and agreed between national and regional partners and they offer a seamless access to digital resources worldwide if a local NREN supports them.

While much of the middleware services, such as essential security services, are invisible to end users, other services such as federated SSO, ${ }^{30}$ for example, Shiboleth (developed by Internet2), and eduGAIN ${ }^{31}$ (developed by GÉANT), will be familiar and welcome to researchers and students if they need to access remote resources or travel to other universities. To take another simple example, eduroam allows a traveling academic or student to go on to the campus of another university in a participating country and be immediately signed in with her credentials upon opening her laptop. SSO may be familiar to users of social media sites when they see that they can sign on to a new service (to them) by using their credentials from another service, for example, signing on to Twitter with one's Facebook username and password. This example is also called Social Sign-on.

The implementation of these services is not a trivial task, and it requires a highly skilled technical team. It is the ability to offer these kinds of services that mark the maturity of an NREN and differentiate it from being merely a bandwidth provider. "NRENs tend to be firmly established and trusted within their community: they are considered to be a part of the community and not just a service provider. This gives them a significant competitive advantage in intermediation between other suppliers and users, and it separates them from commercial operators." ${ }^{32}$ A great deal of effort, therefore, is going on right now in Africa to build the capacity of the operators of NRENs to implement these services in their own networks, much of it funded by the EU and supported by international development partners (see Annex $C$ for details).

\footnotetext{
${ }^{30}$ It is 'federated' because it is agreed between federations of universities and service providers.

31 Benefits of edugain can be seen in this video:

http://services.geant.net/edugain/About_eduGAIN/Benefits_of_eduGAIN/Pages/Home.aspx

32 TERENA ASPIRE report: The Future of NRENs. September 2012.

https://www.terena.org/activities/aspire/docs/ASPIRE-future-of-nrens.pdf
} 


\section{NREN Developments in Sub-Saharan Africa}

\section{Bandwidth, Consortia, and the Beginnings of NRENs}

While the Internet was expanding from academia into every part of economic and social life in the United States and Europe in the nineties, Africa remained relatively isolated due to the lack of telecom infrastructure that could support that take-up and expansion. Most Internet access in Africa up to 6 years ago was through satellite systems (Very Small Aperture Terminals [VSATs]) that were extremely expensive and slow. The cost of bandwidth in Africa was approximately fifty times the cost of bandwidth in the United States and Europe (and in earning power terms nearer to 5,000 times). Individual universities in African countries found it very difficult to afford anything but the most basic 512 kilobits per second (Kbps) to 2 megabits per second (Mbps) connections, dealing as they were with monopolistic telecom operators, no deployment of terrestrial or intercontinental fiber, and the lack of Internet exchanges on the continent. Most Internet traffic went through the United States by VSATs with Africans paying the cost of access.

When undersea fiber optic cables finally reached African coasts in the last decade (see figure 7) and terrestrial networks were rolled out to connect to them, there was a rapid growth in ISPS competing for market share in an evolving environment. An obvious market for them was the university sector where awareness of NRENs was generally confined to a small number of IT staff in larger universities. The few pioneers who were trying to establish NRENs had difficulty explaining the benefits of a dedicated REN when all that most administrators thought was necessary was commodity Internet services, and at the lowest price. The narrative was about price alone at a time when emerging NRENs did not have the skills or resources to offer any more sophisticated services than simple Internet bandwidth.

As outlined earlier, well-established NRENs provide a whole host of added services including such as AAls and other 'middleware' that has enabled the emergence of global collaborative communities in education and research through simplifying access to resources and services. These systems of federated identity management are one aspect of what differentiates an NREN from an ISP. They both provide Internet access but only the NREN, being inside the academic community and with the agreements with international partners, has the key to open the doors to the digital resources and collaboration potential of the global education and research community.

Much work is being done by the champions of research and education networking in Africa to raise the awareness of decision makers in government and academia to the potential benefits of NRENs and the need to build their capacity to avail of the benefits only they can provide. They begin with the economic case, demonstrating that by aggregating demand from all of the universities and other potential members, a value for money proposition can be made to establish an NREN. As part of that argument a lesson in how Internet bandwidth is sold and managed can enlighten management about the performance that they are getting for their money. Going beyond the economic case can be taxing as the added services that are the real value added of NRENs are generally not in place to be demonstrated. 
figure 7. Submarine Fiber Cables Reaching Africa, Up To 2018 (courtesy: Steve Song)

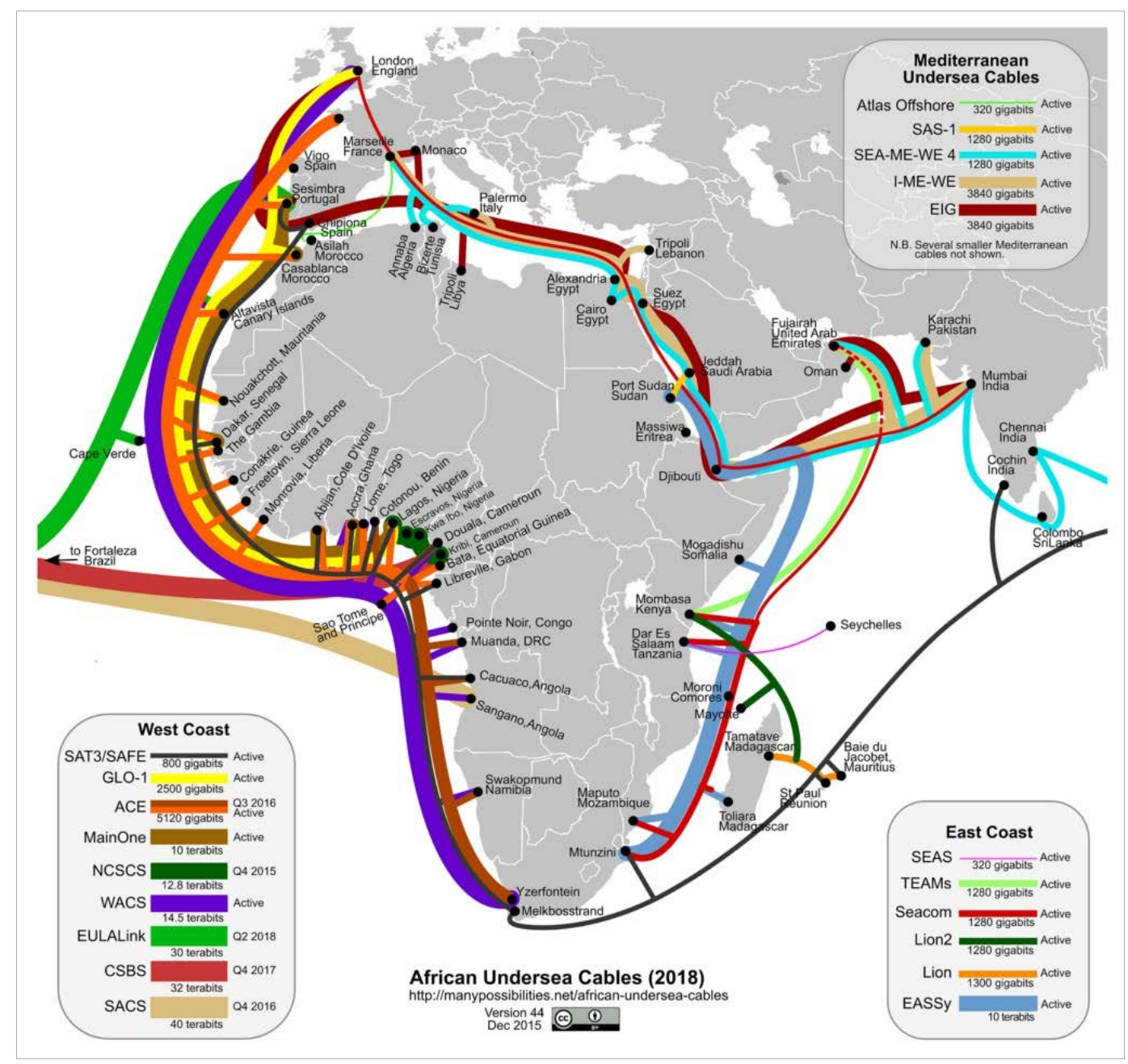

(source: https://manypossibilities.net)

\section{Early Efforts}

In the early years of this century, there were many African and development partner initiatives to build bandwidth consortia to bring economies of scale to the purchase of Internet access for education in Africa. The Program for African Research and Education Networking (PAREN) of the IDRC of Canada, and the African Virtual University's Bandwidth Consortium, were two such initiatives. Yet bandwidth alone was not the only issue. For more than 20 years NRENs in Europe and in the United States were fueling innovation in networking technologies and catalyzing scientific cooperation at a global level. Africa was unable to take full advantage of this opportunity due to lack of adequate infrastructure. In other regions it was accepted that bandwidth demand and access services for many e-Science applications and collaborations could not be met at a reasonable cost by using the commercial, or commodity Internet infrastructure. A dedicated network for the research and education community was necessary. RENs were considered even more crucial for Africa due to researchers' isolation, and the need to participate in global research projects, in resource sharing, and to gain access to teaching and learning content. 
At the 11th General Conference of the AAU held in Cape Town, South Africa, in February 2005, the AAU established a role within the association for coordination of the many ICT initiatives currently underway in their member institutions. At that time there were only two NRENs operating in Sub-Saharan Africa: TENET in South Africa and KENET in Kenya. The AAU commissioned a report to advise on how a consortium approach could be used to bring affordable bandwidth to African universities. The report, ${ }^{33}$ prepared by F. F. (Tusu) Tusubira and Nora K. Mulira set in motion a chain of activities that resulted in the launch of the UbuntuNet Alliance, the establishment of a REN unit in AAU, a continent-wide association called AfREN, and eventually WACREN.

The AAU REN unit was set up in 2006 with the support of the IDRC, the Partnership for Higher Education in Africa and the African Capacity Building Foundation to:

a) Act as focal point for ICT initiatives for the higher education sector.

b) Set up and maintain a clearinghouse for resources on ICT policy and research and education networking.

c) Promote the establishment of RENs.

d) Advocate for access to adequate and affordable bandwidth for African Higher Education and research institutions.

e) Raise awareness among policy and decision makers.

f) Support capacity-building activities in collaboration with partners such as the African Network Operators Group (AfNOG), the African Network Information Centre (the Internet Numbers Registry for Africa) and the NSRC of the University of Oregon.

The REN unit is carrying out these activities since its foundation and it has been instrumental in the strengthening of the UbuntuNet Alliance and the establishment of WACREN.

\section{The Regional Research and Education Networks (RENs)}

By 2005 the gradual rollout of terrestrial fiber optic cables in East Africa and the planned EASSy and SEACOM submarine cable initiatives were the catalysts for academic networking champions to finally see the possibilities for NREN development in Africa. At the Internet2 Fall meeting in Philadelphia during an informal chat among a group of African pioneers in the hotel lobby, Duncan Martin, then CEO of TENET of South Africa, mooted the name 'UbuntuNet' for a regional REN. 'Ubuntu' is a Nguni Bantu word meaning 'human kindness' but is used in the philosophical sense to mean 'the belief in a universal bond of sharing that connects all humanity'. ${ }^{34}$ In November 2005 the AAU's Communications and ICT department organized the launching of the UbuntuNet Alliance in Tunis during the World Information Summit (WIS), and in March 2006 it was formally registered as an association.

${ }^{33}$ Tusubira, F. F., and Nora K Mulira. The Proposed role of the AAU: Enabling Members and

Associated Institutions to Access More Bandwidth at Lower Cost.

34 "About the Name". Official Ubuntu Documentation. Canonical. Retrieved January 5, 2013. 


\section{The UbuntuNet Alliance - the Beginnings ${ }^{35}$}

Working with the AAU REN unit, which provided continent-wide policy-level stimulus, guidance, and international governmental-level negotiations and linkages, the alliance members saw their role as enabling connectivity of national and regional RENs at high speed, with sufficient and affordable connection to each other and the international research community via fiber. Their major challenge was the price of Internet connectivity, which in 2006 was exclusively by VSAT and ranged from US $\$ 1,000$ per megabit per second per month to an eye-watering US $\$ 6,750$ per megabit per second per month. The SEACOM cable would not be operational until July 2009 and EASSy a year later.

The UbuntuNet Alliance in its charter invites members from Eastern and Southern Africa, which is defined as the region comprising the Democratic Republic of Congo and Sudan, and all African countries that lie either to the east or to the south of the Democratic Republic of Congo and/or Sudan, together with the island countries in the western reaches of the Indian Ocean, 26 countries in total. All NRENs, transnational communities of practice, and transnational companies or organizations providing services relevant to the Alliance and its members are eligible to apply. In 2006 only three countries, Kenya (KENET), South Africa (TENET) and Sudan (SUdREN) had a formal REN established with an underlying operational structure, but none had an advanced network with sufficient bandwidth. The Democratic Republic of Congo (eb@le), Malawi (MAREN), Mozambique (MoRENet), Rwanda (RwEdNet), Tanzania (TERNET), and Zambia (ZAMREN) had the formal structure of a NREN but no supporting physical infrastructure.

The challenges were great: a huge and diverse continent, limited competition in telecoms, especially for international gateways, very little fiber reaching to Africa at that time (just SAT3 cable to South Africa), a scarcity of technical human capacity, a lack of awareness on research networking in member countries, and extremely limited funding.

The UbuntuNet Alliance responded vigorously to these challenges by engaging national and regional administrations, making the case for liberalization of regulatory policy, and for special consideration for research and education networking as a development stimulant. Capacitybuilding initiatives were organized through communities of practice, partnerships with the AfNOG, and the creation of a network-engineering group. They sought donations of IRUs on the upcoming fiber capacity, getting a donation of $10 \mathrm{Gbps}$ on SEACOM for the Eastern cluster from the Internet Educational Equal Access Fund (a U.S.-based organization), and TENET secured IRUs at concessionary rates on SEACOM for the Southern cluster. With the low awareness of NRENs in the member countries much work was done to promote knowledge of the benefits of REN activities and to actively seek contacts to start NRENs, and to lobby national governments to increase public funding of NREN activity, based on clear business cases and models.

In planning the network, the strategy was to build the UbuntuNet backbone using a staged approach to connect clusters of NRENs by building out from existing cross-continental links using the opportunities provided by existing and planned fiber infrastructure projects. They identified two initial clusters, based on existing and planned fiber opportunities: UbuntuNet East - Kenya, Sudan, Ethiopia, Uganda, Rwanda, Burundi, and Tanzania and UbuntuNet South - Malawi, Zambia, Zimbabwe, Namibia, Tanzania, South Africa, Lesotho, Swaziland, and Mozambique. Ultimately, the clusters would interconnect into a seamless, single redundant (that is, with back-up connectivity in case of failure) backbone. This African backbone would allow African traffic to stay in Africa, thus saving on international traffic costs. An inter-regional connection was planned to be part of the AfricaConnect2 project.

By July 2016 the UbuntuNet Alliance membership consisted of Kenya, Zambia, Mozambique, Tanzania, South Africa, Burundi, Rwanda, Uganda, the Democratic Republic of Congo, Ethiopia,

${ }^{35}$ UbuntuNet Alliance: http://www.ubuntunet.net 
Sudan, Somalia, Malawi, Namibia, and Madagascar. The countries that need to create NRENs and to join the UbuntuNet Alliance are Angola, Botswana, Comoros Islands, Djibouti, Eritrea, Lesotho, Mauritius, Seychelles, South Sudan, Swaziland and Zimbabwe.

\section{West and Central African Research and Education Network ${ }^{36}$}

The WACREN initiative started in 2006 at workshops of AfNOG and AAU. AAU hosted a further consultative workshop in 2009, and WACREN was formally established in 2010, with a Board registered in March 2011. The challenges for WACREN were similar to those encountered by the members of the UbuntuNet Alliance in 2006: an inadequate telecommunications regulatory environment with a near-monopoly position of operators in many countries; costly VSAT technology still widely used; lack of human technical capacity; and unreliable power supply. While some progress has been made, the need for strong advocacy of NRENs to raise the awareness among governments and other potential donors remains.

WACREN covers the 22 countries of West and Central Africa, but not all of them are participating in the association. The current membership, as of July 2016 comprises Benin, Burkina Faso, Cameroon, Cote d'Ivoire, Gabon, Ghana, Mali, Niger, Nigeria, Senegal, and Togo.

The Senegalese NREN snRER was delegated to host the first NOC of WACREN with the intention of connecting to GÉANT in Paris through RENATER, the French NREN, when capacity allowed. In 2011 RENATER became the first international member of WACREN along with two of its French member institutions CIRAD and IRD. Patrick Donath, director of RENATER explained at the signing that "RENATER's mission is also to help West and Central Africa to bridge the digital divide by bringing its network expertise to promote the development of science, education and North/South cooperation within the African continent."

Since its founding WACREN has established a secretariat and hired a CEO, a chief technology officer (СTO) and an office administrator with some help from the AfricaConnect project and from other donors. There are regular board meetings and platforms have been established for communications and coordination between NREN CEOs and also for CTOs or their equivalent technical contacts.

\section{Arab States Research and Education Network ${ }^{37}$}

ASREN was launched in December 2010 as an expansion of the EUMEDCONNECT project that was largely funded by the EU to link Mediterranean countries to GÉANT. The African countries in ASREN are, west to east: Mauritania, ${ }^{38}$ Morocco, Algeria, Tunisia, Egypt, Sudan, Djibouti, Somalia, and Comoros. ${ }^{39}$ While some of these countries have direct connections to Europe none of them connect to each other. The AfricaConnect2 project includes the African countries of ASREN, in place of the EUMEDCONNECT project, as a third African cluster with UbuntuNet Alliance and WACREN.

\footnotetext{
${ }^{36}$ WACREN: http://www.wacren.net

${ }^{37}$ ASREN: http://asrenorg.net

${ }^{38}$ Also in the WACREN cluster.

${ }^{39}$ Sudan, Djibouti, Somalia, and Comoros are also members of UbuntuNet Alliance.
} 


\section{The AfricaConnect Project - A Catalyst for the Growth of NRENs in Africa}

\section{Background}

In their partnership on Science and Technology the African and EU Commissions gave high priority to connectivity between African and European research and education institutions through the AfricaConnect project. In 2008 the European Commission (EC) initiated a feasibility study called FEAST to explore the potential of deploying a regional backbone connecting dedicated NRENs in Africa to each other and to their peers on other continents via GÉANT, the pan-European REN backbone. The study was carried out by the KTH Royal Institute of Technology in Sweden as main contractor and DANTE and TERENA as subcontractors. As mentioned in the previous chapter DANTE was the agency that operated GÉANT and TERENA was the association of European NRENs. They have recently merged into one organization called GÉANT. ${ }^{40}$

In summary, the FEAST project recommended:

- Deepening the cooperation with UbuntuNet Alliance and its member NRENs by inviting them to join an AfricaConnect consortium, as partners or subcontractors, together with DANTE, TERENA, and interested European NRENS, with the objective to reinforce the emerging UbuntuNet regional REN connecting their member NRENs to each other and to the panEuropean REN, GÉANT.

- Continuing and deepening the direct twinning between African and European NRENs.

- Ensuring that resources are made available for demonstration projects showcasing the benefits of the investments made via the AfricaConnect Initiative in the reinforcement of the UbuntuNet regional REN, and to motivate further investments in a second phase.

- Involving the AAU as a partner and making resources available for capacity building and supporting the establishment of WACREN and not-yet-ready NRENs to prepare them for participation in a second phase.

- Involving African higher education institutions in capacity building to meet the expected demand also from other sectors of society and ensuring that resources are made available for capacity building and training necessary to make AfricaConnect first phase a success and to prepare for a second phase. ${ }^{41}$

\section{Achievements and significance of AfricaConnect}

The AfricaConnect project, a €14.75M project funded 80 percent by the EU has provided a significant boost to the development of research and education networking in Africa. Building on and supporting the early work of the AAU's REN unit, the project's scope and timeline has become the de facto timeline of the regional developments up to this, and the AfricaConnect2 project aims to take developments a stage further. Details of both phases are in Annex II. The achievements of the project include:

40 GÉANT Association: http://www.geant.org

${ }^{41}$ Feasibility Study on the AfricaConnect Initiative. Final Report. http://www.feast-

project.org/documents/FEAST-Final-Report-2010-03-22.pdf 
a) The establishment of points of presence (PoPs) in Eastern and Southern African countries and their interconnection by broadband cross-border links. This has enabled the UbuntuNet network to keep African Internet traffic in Africa, reducing delays and costs and encouraging more collaboration among researchers and students.

b) The acquisition of submarine fiber links to Europe which connects UbuntuNet member NRENs to all the NRENs of Europe through the GÉANT network and onwards to other regional networks in the Americas and Asia.

c) The establishment of a secretariat in West Africa for the WACREN association.

d) In association with a series of capacity-building programs, a cadre of well-trained engineers is in place to further develop the services provided by national RENs.

\section{Capacity-Building Programs and Projects Supporting NREN Services Development in Africa}

While AfricaConnect is concerned with the fiber optic communications links between NRENs in Africa and the wider global REN community, there is more to NRENs than merely connectivity and bandwidth. To move from providing basic connectivity services to a position where they can support a range of collaborative tools, gateways, and the 'middleware services' described earlier, African NRENs will require highly skilled and well-trained personnel.

UbuntuNet Alliance and WACREN have sponsored regular capacity-building events since 2012 in partnership with AfricaConnect, NSRC, SIDA (Sweden), IDRC (Canada), the Dutch government and International Network for the Availability of Scientific Publications (United Kingdom) to train network engineers at campus and NREN level. This was done typically through training workshops mostly at NREN level, by NRENs training IT personnel from member institutions in campus networking skills. Both associations are partners in a number of projects, many of which are funded by the EC's Horizon 2020 Research and Development program, which will build their capacity, and the capacity of their member NRENs to deploy these services. The details of the projects are described in Annex III. 
The Role and Status of National Research and Education Networks (NRENs) in Africa 


\section{Status of the NRENs of Africa By Region (June 2016)}

\section{Stages of Development of African NRENs of Africa by Region}

NRENs come into existence through varied pathways, which can be characterized as either bottom-up evolution or a top-down big bang approach, or there can be a mix of both shades in between. This latter scenario can occur where a long gestation effort pushed by champions (bottom-up) is rewarded with a commitment by government, possibly aided by an external source of finances, to fund a national plan (top-down). The Capability Maturity Model ${ }^{42}$ is a measure of development designed for the software industry, and Duncan Greaves of TENET, South Africa's NREN, applied it usefully to describe the typical stages of development of NRENs, mainly on the bottom-up approach but it can serve as a useful guideline as to where on the scale various NRENs in a region lie. A summary of the Greaves' levels of development is given below and applied to the African NRENs by region (figures 8-10) and continent-wide (figure 13). The details of individual NRENs are available in Annex I.

Level 0: No NREN and no awareness of the need. This occurs in countries where there are a number of factors at work that inhibit the establishment of an NREN, such as lack of awareness of the nature and benefits of an NREN, lack of physical network infrastructure, or its high cost. The commodity Internet is seen as sufficient for the needs of the universities.

Level 1: No NREN but a diffused consciousness of the benefits of establishing one. A bandwidth shortage can lead to the formation of a 'buying club' for purchasing bulk bandwidth from an ISP. It is the beginning of a consortium that could be developed into an NREN.

Level 2: No NREN but a more structured conversation regarding one. This is the stage at which the group of champions has a more focused view of what is required and begins to approach university management and government for support. It can be prompted by changed conditions, donor prompting, regulatory improvements, but it requires strong leadership to proceed to the next level.

Level 3: No actual NREN but a formal commitment to proceed is achieved. The consensus is formalized with signed memorandums of understanding between institutions promising to collaborate, and recognized by government, but before a physical network is established. Staff in universities and ministries are still working on a voluntary basis at the planning stage. This is a delicate stage and progress needs to be seen to keep the consensus alive.

Level 4: A formal NREN organization with services is established. A legal entity with paid staff and power to make contracts and offer services. Connectivity is provided to members through contracts with providers for services, and a business plan and business model is being implemented. It remains vulnerable to predatory competition from commercial operators because it is not yet able to provide the advanced services that distinguishes it from an ISP.

Level 5: First REN to REN international links are established. The benefits include faster connectivity to remote academic resources and participation in the wider global and/or regional REN community.

42 Duncan Greaves. http://www.ubuntunet.net/sites/default/files/NREN_Capability_Maturity.pdf 
Level 6: The NREN begins to offer REN-specific advanced services. This stage marks the full maturity of the NREN as it delivers value-added services specific to academic collaboration such as federated identity services, access to grid computing, science gateways, user-controlled lightpaths, and so on. This is where the NREN comes into its own.

\section{Some caveats: Nuances within levels}

These levels are not watertight, as the stages of development of an NREN are more nuanced than the numbers suggest. The levels can leak between levels 3 and 4 and between 4 and 5 . To take the latter case, one NREN may have an advanced internal network but is not connected internationally to another REN, while another NREN can have the international connection but have a less developed internal service. In these cases a 3.5 or a 4.5 may be the more appropriate grade. A similar situation may arise between levels 3 and 4 where an NREN is ready to implement an internal network but requires the seed funding from government to begin operating. Yet another variable is the amount of bandwidth provided by an NREN to member institutions. Given the very low capacity provided by VSAT systems for years, the expectations among universities can be quite low and the rules of supply and demand do not always apply. Very often it is a case of 'if you don't expect much you don't demand more', or conversely, when offered a huge increase in bandwidth the demand can soar-a case of 'if you build it they will come'. Therefore, while a number of NRENs may have adequate connectivity and monitoring services in place, the actual bandwidth provided to institutions may be quite low compared to practice elsewhere. This situation will most likely change as bandwidth prices fall further and usage rises, but it is yet another variable in the stages of development of an NREN. These more subtle variables are reflected in the numbers on the charts and in the color tones in the map, and comparable NRENs may achieve their level on different criteria. 
Table 1. List of Countries in Africa and their NREN Status

\begin{tabular}{|c|c|c|c|c|}
\hline Country & NREN & Region/Membership & Op. Status & Level \\
\hline 1. Angola & & UbuntuNet S/No & Planning & 1 \\
\hline 2. Botswana & & UbuntuNet S/No & Planning & 2 \\
\hline 3. $\quad$ Burundi & BERNet & UbuntuNet E/Yes & Operational & 4 \\
\hline 4. Comoros & & UbuntuNet/ASREN/No & Planning & 1 \\
\hline 5. Congo, Dem. Rep. & $E b @ / e$ & UbuntuNet E/Yes & Planning & 2.5 \\
\hline 6. Eritrea & & UbuntuNet E/No & Planning & 1 \\
\hline 7. Ethiopia & EthERNet & UbuntuNet E/Yes & Operational & 4.5 \\
\hline 8. Kenya & KENET & UbuntuNet E/Yes & Operational & 6 \\
\hline 9. Lesotho & & UbuntuNet S/No & & 0 \\
\hline 10. Madagascar & iRENALA & UbuntuNet/Yes & Operational & 4 \\
\hline 11. Malawi & MAREN & UbuntuNet S/Yes & Planning & 2.5 \\
\hline 12. Mauritius & & UbuntuNet/No & Planning & 2 \\
\hline 13. Mozambique & MoRENet & UbuntuNet S/Yes & Operational & 4.5 \\
\hline 14. Namibia & XNet & UbuntuNet S/Yes & Operational & 4 \\
\hline 15. Rwanda & RwEDNet & UbuntuNet E/Yes & Planning & 2.5 \\
\hline 16. Seychelles & & UbuntuNet E/No & Planning & 1 \\
\hline 17. Somalia & SomaliREN & UbuntuNet/ASREN/Yes & Planning & 2 \\
\hline 18. South Africa & TENET & UbuntuNet E/Yes & Operational & 6 \\
\hline 19. South Sudan & & UbuntuNet E/No & Planning & 1 \\
\hline 20. Sudan & SUdREN & UbuntuNet /ASREN/Yes & Operational & 4.5 \\
\hline 21. Swaziland & & UbuntuNet S/No & Planning & 2 \\
\hline 22. Tanzania & TERNET & UbuntuNet E\&S/Yes & Operational & 4.5 \\
\hline 23. Uganda & RENU & UbuntuNet E/Yes & Operational & 5 \\
\hline 24. Zambia & ZAMREN & UbuntuNet S/Yes & Operational & 5 \\
\hline 25. Zimbabwe & & UbuntuNet S/No & Planning & 2 \\
\hline 26. Benin & RerBenin & WACREN/Yes & Planning & 3 \\
\hline 27. Burkina Faso & FasoREN & WACREN/Yes & Planning & 3 \\
\hline 28. Cameroon & RIC & WACREN/Yes & Planning & 3 \\
\hline 29. Cape Verde & & WACREN/No & Planning & 2 \\
\hline 30. Central African Republic & & WACREN/No & $?$ & 0 \\
\hline 31. Chad & & WACREN/No & Planning & 2 \\
\hline 32. Republic of Congo & & WACREN/No & $?$ & 0 \\
\hline 33. Cote D'Ivoire & RITER & WACREN/Yes & Operational & 4 \\
\hline 34. Equatorial Guinea & & WACREN/No & Planning & 1 \\
\hline 35. Gabon & GabonREN & WACREN/Yes & Planning & 3 \\
\hline 36. The Gambia & & WACREN/No & Planning & 2 \\
\hline 37. Ghana & GARNET & WACREN/Yes & Planning & 3.5 \\
\hline 38. Guinea & & WACREN/No & Planning & 2 \\
\hline 39. Guinea Bissau & & WACREN/No & Planning & 1 \\
\hline 40. Liberia & & WACREN/No & Planning & 2 \\
\hline 41. Mali & MaliREN & WACREN/Yes & Planning & 3 \\
\hline 42. Niger & NigerREN & WACREN/Yes & Planning & 3 \\
\hline 43. Nigeria & NgREN & WACREN/Yes & Operational & 4 \\
\hline 44. Sao Tome and Principe & & WACREN/No & Planning & 1 \\
\hline 45. Senegal & SnRER & WACREN/Yes & Operational & 4 \\
\hline 46. Sierra Leone & & WACREN/No & Planning & 2 \\
\hline 47. Togo & TogoREN & WACREN/Yes & Planning & 3 \\
\hline 48. Algeria & $A R N$ & ASREN/Yes & Operational & 6 \\
\hline 49. Djibouti & & ASREN/UbuntuNet E/No & $?$ & 0 \\
\hline 50. Egypt & EUN & ASREN/Yes & Operational & 6 \\
\hline 51. Libya & & ASREN/No & ? & 0 \\
\hline 52. Morocco & MARWAN & ASREN/Yes & Operational & 4.5 \\
\hline 53. Mauritania & & ASREN/No & Planning & 2 \\
\hline 54. Tunisia & RNU2 & ASREN/Yes & Operational & 4.5 \\
\hline
\end{tabular}


Figure 8. UbuntuNet Alliance - Levels of Development of NRENs in Eastern and Southern Africa based on the Capability Maturity Model (CMM)

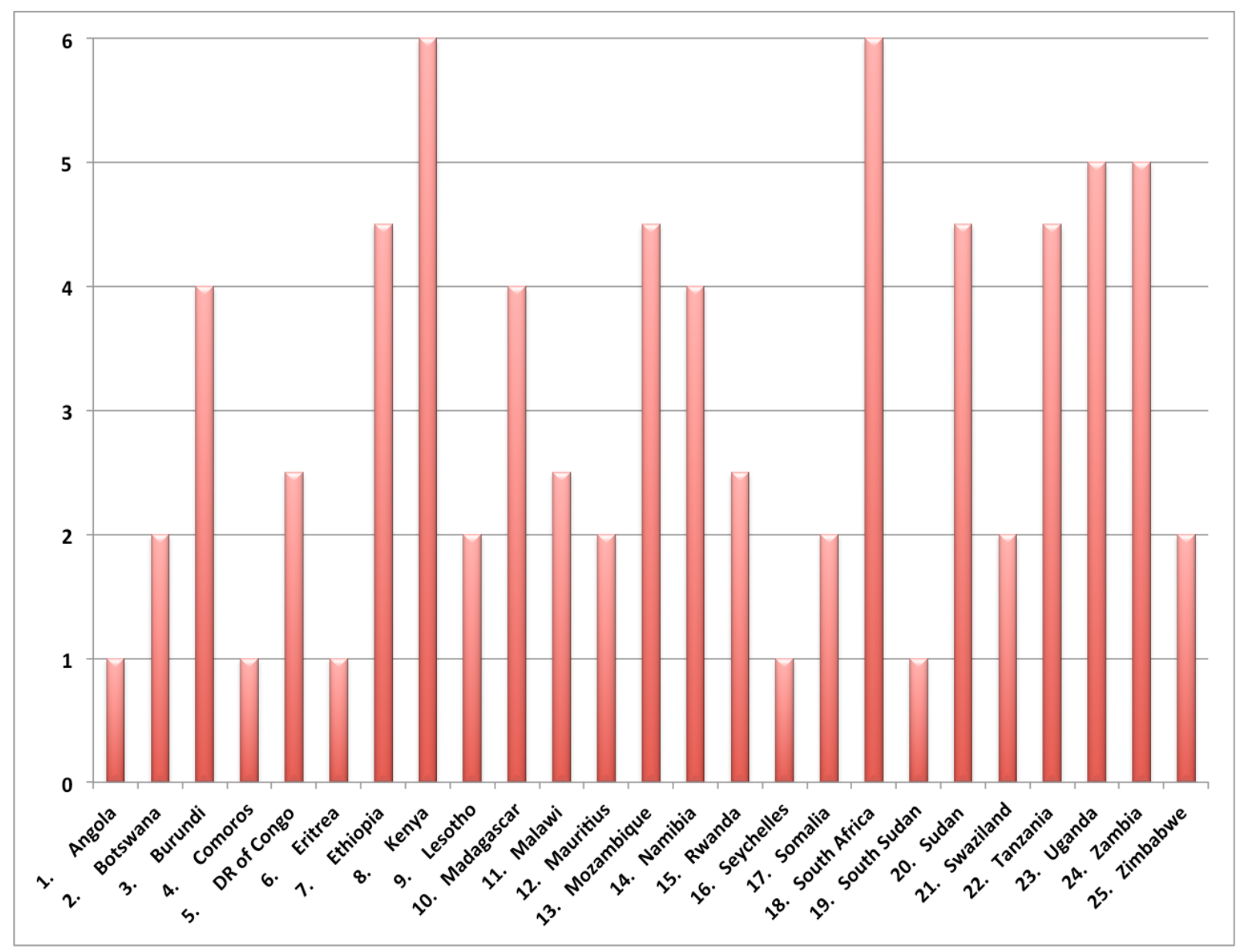


Figure 9. WACREN - Levels of Development of NRENs in West and Central Africa based on the CMM

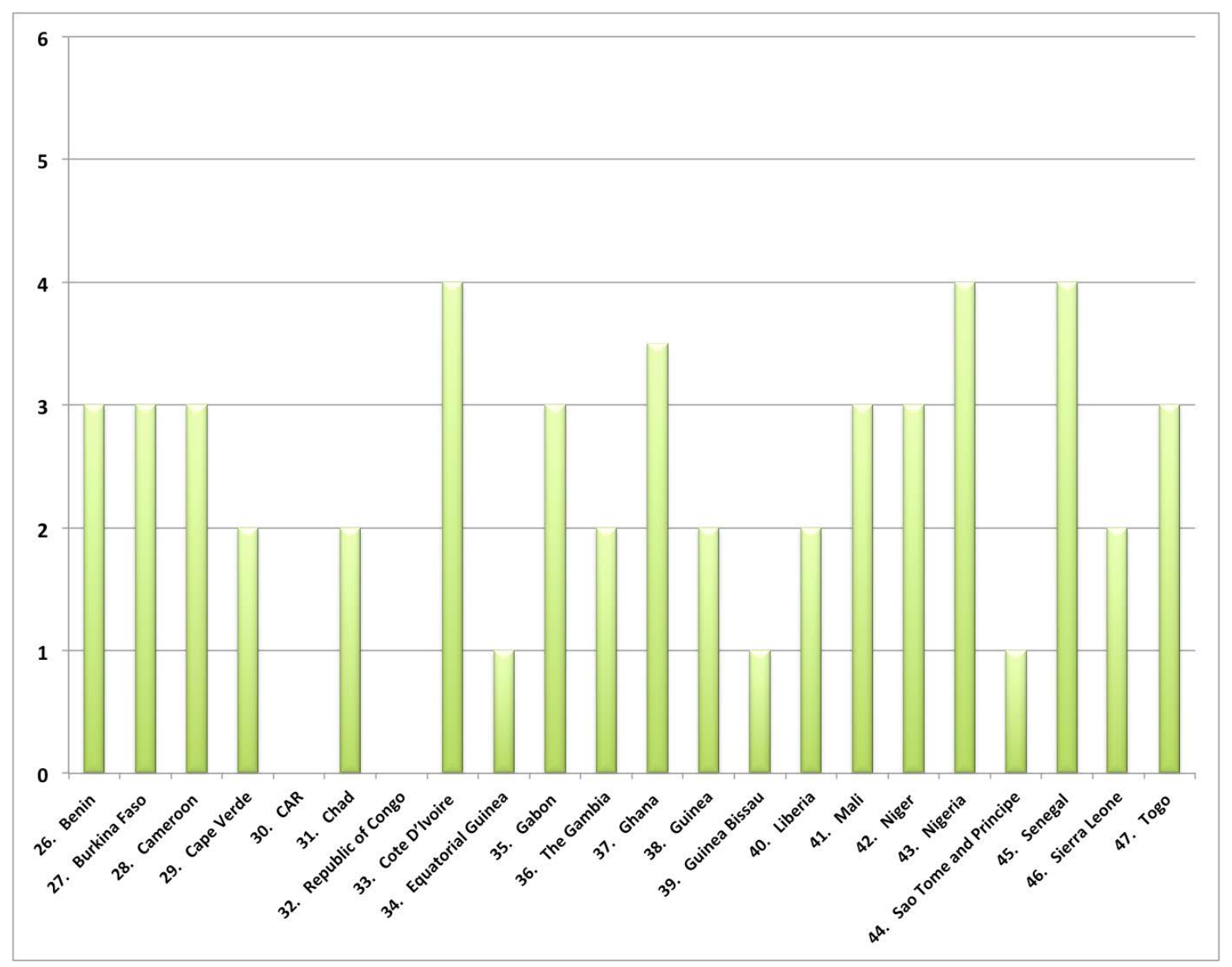

Figure 10. ASREN - Levels of Development of NRENs in North Africa based on the CMM

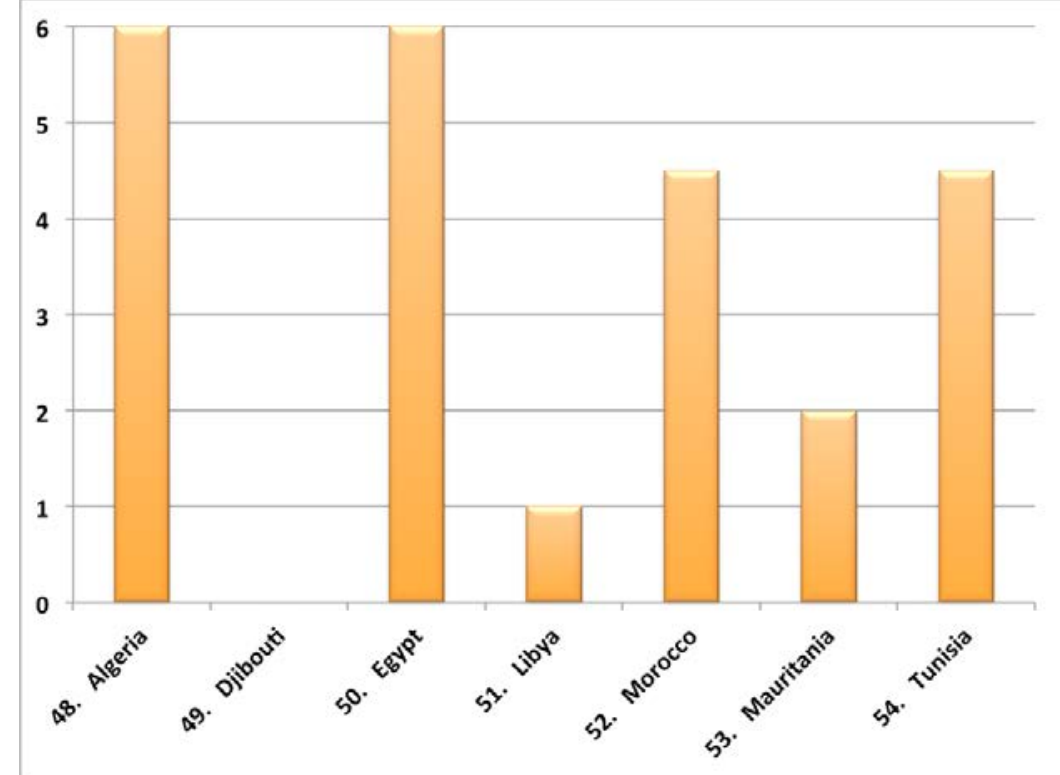




\section{Examples of NREN Topology in Nigeria and Kenya}

These network maps are shown purely to give an impression of how some countries are developing their NREN infrastructure.

Figure 11. NgREN, Nigeria, Network Topology (courtesy: NgREN)

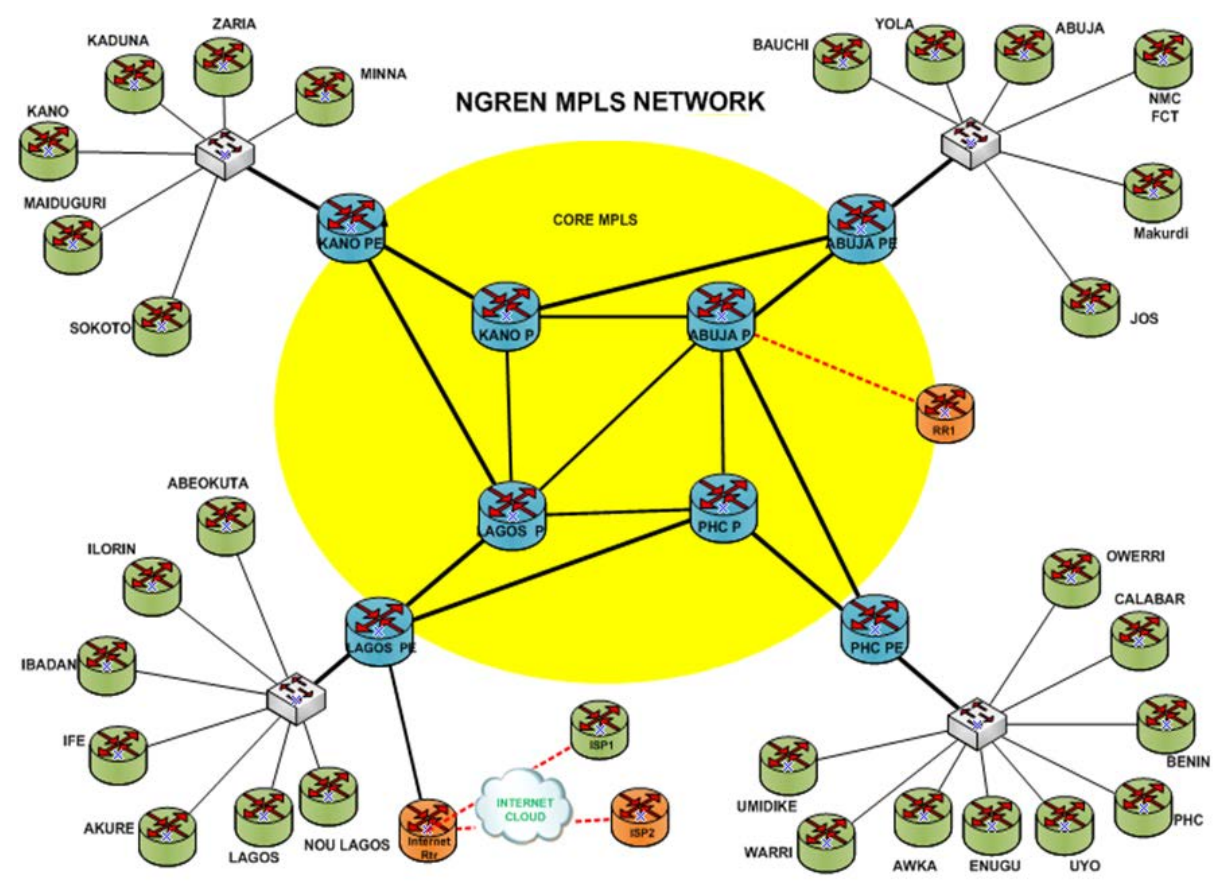

Figure 12. KENET, Kenya Network Topology (courtesy: KENET)

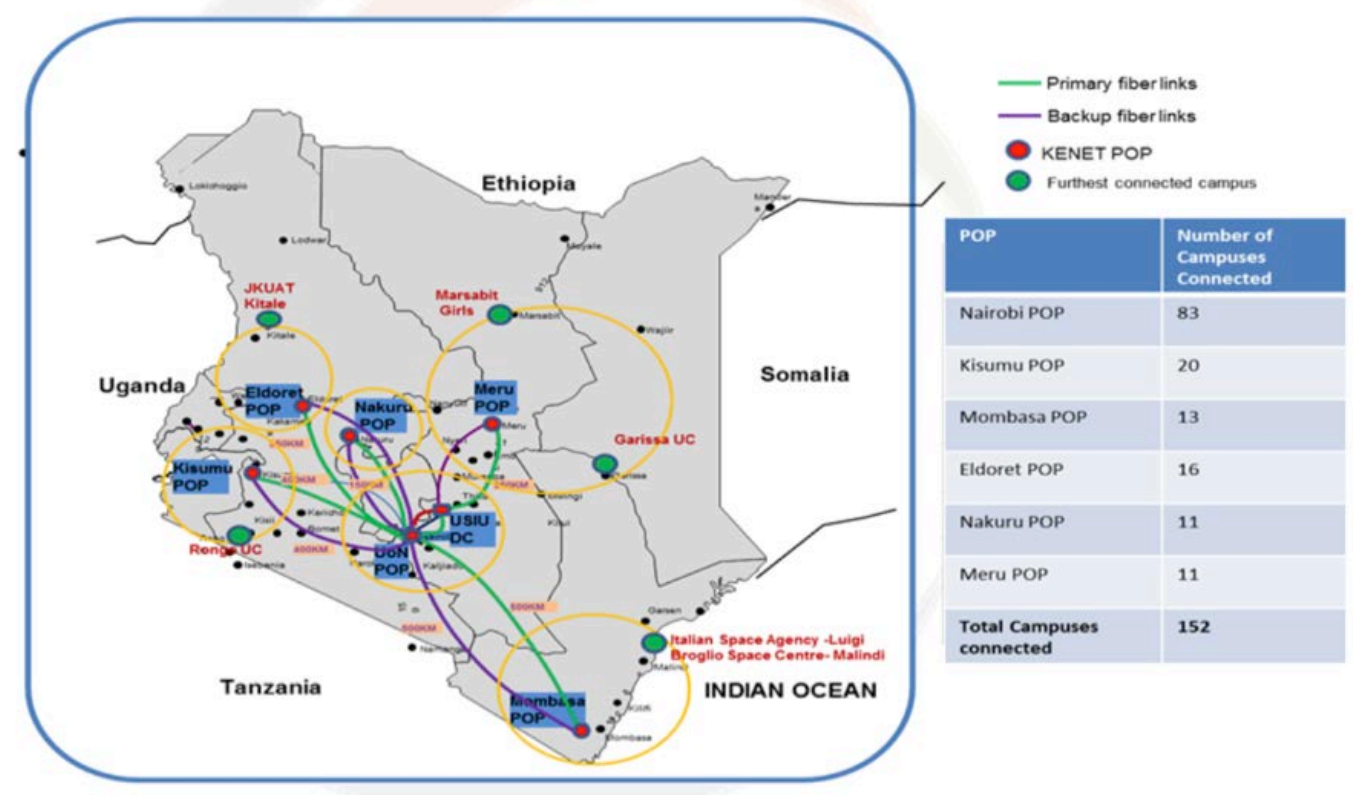




\section{NREN Status and International REN-REN Connectivity in Africa June 2016}

The map in figure 4.6 is a visual summary, as of June 2016, of the maturity status of the NRENs of Africa and of their regional and international connectivity to other RENs. Each country is color coded according to region and the shading from dark to light reflects their level of development according to the Capability Maturity Model described in paragraph 4.1 above. The coloring and shading is explained below and the detailed information on each country is in Annex I.

Figure 13. Levels of Development and Connectivity of African NRENs.

(c) 2016 by International Bank for Reconstruction and Development / The World Bank ${ }^{43}$

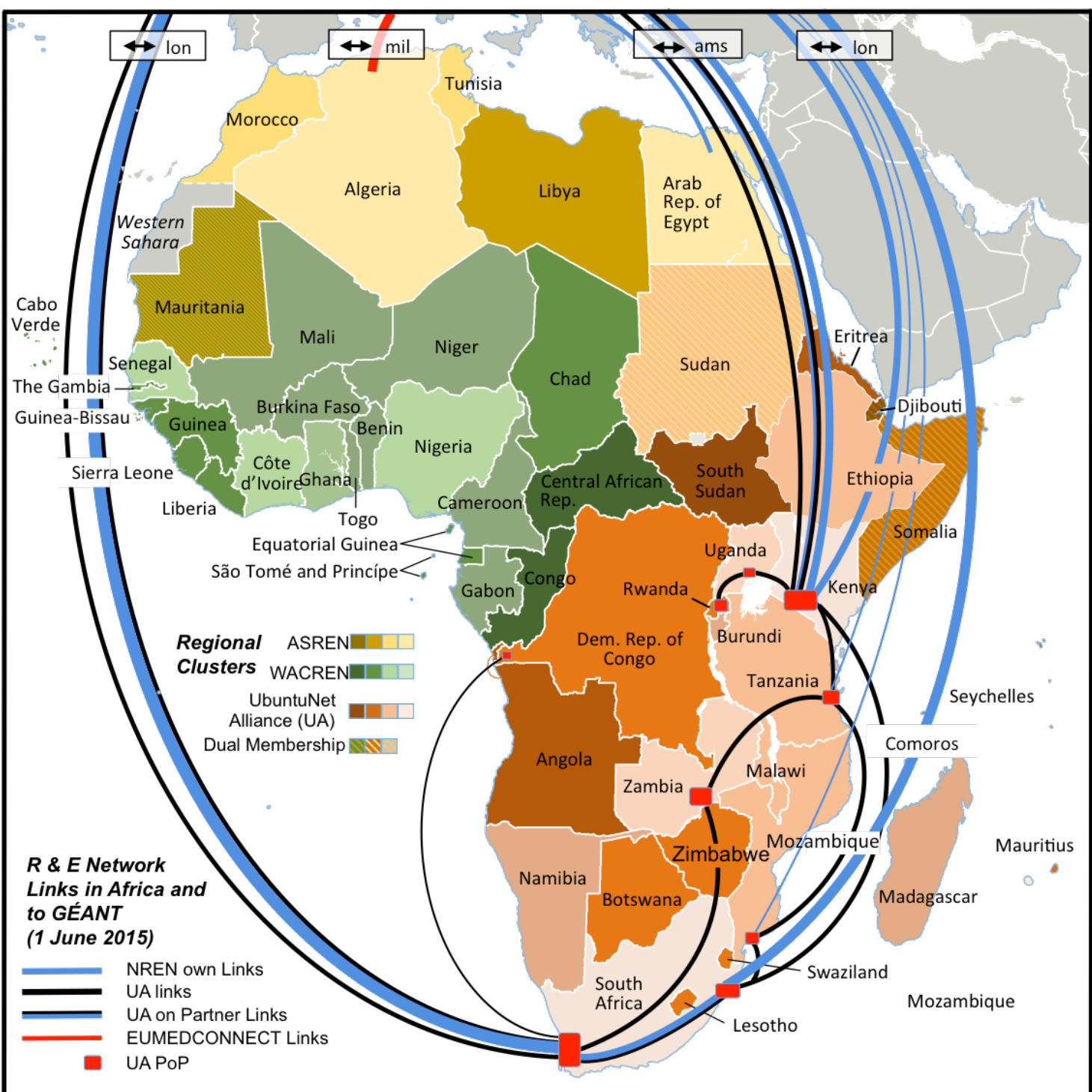

43 The boundaries, colors, denominations, and other information shown on this map do not imply any judgment on the part of The World Bank concerning the legal status of any territory or the endorsement or acceptance of such boundaries. 


\section{Levels of development in the regions}

The coloring in the map relates to regional affiliation as follows: ASREN in yellow, WACREN in green, and UbuntuNet Alliance in brown. A number of countries hold membership in two regional associations, because of their potential as points of interconnection between regions. Sudan, Somalia, Comoros, and Djibouti are members of ASREN and UbuntuNet Alliance, and the Democratic Republic of Congo and Mauritania plan to apply for membership of WACREN while continuing to be members of UbuntuNet Alliance and ASREN respectively.

The shading level of each country, from dark to light is based on where they lie on the six levels of maturity of the development of their NREN, with the darker the shade reflecting the least activity and the lightest shade the greatest maturity.

\section{REN to REN connectivity links}

The connectivity links shown in the map here refer only to REN-REN links between African NRENs, and to the links to and from Europe. The European links terminate either at UbuntuNet Alliance PoPs in London (Ion) and Amsterdam (ams), or directly to GÉANT in Amsterdam (from Egypt) or Milan (mil - from Algeria). From these exchange points African NRENs can peer with all other NRENs globally, and transit to the commodity Internet. The links are color coded black, blue, blue and black, or red, according to the legend in the map and described in detail below.

The black lines in the map refer to the UbuntuNet Alliance regional network and as of July 1 , 2016, it has the following resources:

- Ten PoPs, eight in the Eastern and Southern Africa (ESA) region and two in Europe, in London (lon) and Amsterdam (ams)

- A backbone covering seven countries in the ESA region

- A2.18 Gbps capacity between the ESA and European PoPs

- Two links along the east coast and two on the west

The blue lines refer to the links of individual NRENs that connect directly to the European UbuntuNet PoPs:

- KENET (Kenya) - 2xSTM-4, 1xSTM-1, 1xSTM-16 (approximately 3.9 Gbps in total). KENET also has an STM-16 (2.5 Gbps) link to commodity Internet at Fujairah in the United Arab Emirates (not shown)

- MoRENet (Mozambique) - 1xSTM-1 (155 Mbps)

- TENET (South Africa) - 1×10 Gbps, 1X20 Gbps

- TERNET (Tanzania) - 1xSMT-1 (155Mbps)

- $\quad$ Egypt (EUN) direct STM-4 connection to GÉANT at ams

The Blue and black lines show the UbuntuNet links that share capacity on partner links, namely on one of the TENET (South Africa) links to London and on one of the KENET (Kenya) links to Amsterdam.

The red line refers to the EUMEDCONNECT 622 Mbps link between ARN, the Algerian NREN, and a GÉANT PoP in Milan (mil).

UbuntuNet peers (free exchange of traffic) with GÉANT in London and Amsterdam to exchange research and education traffic with GÉANT member NRENs and with other regional RENs that peer with GÉANT. It also has commodity Internet peering arrangements at the London Internet Exchange (LINX) and the Amsterdam Internet Exchange (AMS-IX) 'settlement free' (no 
payment) and also at the NAPAfrica also settlement free. It also pays for some transit at LINX and AMS-IX.

Note: Some African NRENs have additional international connections to the commodity Internet with exchange points in Europe and the Middle East (for example, KENET). While these links are not shown on the map, due to space restrictions, they should not be underestimated in their contribution to teaching and learning in Africa, as the majority of digital learning resources are accessed through the commodity Internet.

\section{Plans for the Future: AfricaConnect2 (July 2015-December 2018) ${ }^{44}$}

On a regional basis the immediate future development of research and education networking in Africa is based on the AfricaConnect2 project, a consolidation and extension of the achievements of the AfricaConnect phase one project. AfricaConnect2 will be a €26.6M panAfrican project (including North Africa), of which €20M will be co-funded by the EC's DirectorateGeneral International Cooperation and Development. ${ }^{45}$

The project will be for a three-and-a-half-year period from July 2015 to December 2018 covering the three clusters of NRENs corresponding to the regional associations of ASREN, WACREN, and the UbuntuNet Alliance. The aim of the project in Eastern and Southern Africa is to consolidate the gains in phase one and to add more countries to the UbuntuNet Alliance network. In the WACREN region the aim is to select a minimum of three NRENs, based on legal and technical criteria, and to connect them into a regional terrestrial network and to GÉANT via a direct connection between the region and a PoP in Europe. Further details of AfricaConnect2 are in Annex II.

44 Information provided by GÉANT

${ }^{45}$ Directorate-General International Cooperation and Development (DG DEVCO) 
The Role and Status of National Research and Education Networks (NRENs) in Africa 


\section{Trends and Prospects in the Use of NRENs}

This section aims to review what are considered to be the trends in the use of technology in teaching, learning, and research, and how these innovations would impinge on the need and use of NRENS.

\section{Teaching, Learning, and Research in a Digital Age}

As mentioned earlier, a key factor holding back the widespread use of Internet in Africa was the historically high cost of Internet access and affordability of technology. Both of these challenges are receding as cost of Internet plummets and computing power in the form of cheap laptops, tablets, and smart phones becomes affordable. In an e-readiness study ${ }^{46}$ completed in 2013 by the KENET, it was noted that 50 percent of students in Kenyan universities owned their own laptops. In a number of studies ${ }^{47}$ in Nigeria, the common factor inhibiting greater use of Internet in the universities was the low level of connectivity at the campus level, leading to very slow download speeds, and the high cost of access through commercial Internet cafes. The typical frequency of use of the Internet by students then was, on average, three or four times a week. The most common usage of the Internet has been for e-mail and web searching. The slow speed of available access would inhibit more advanced uses or even more frequent use. However, these studies were carried out in the days of satellite access to Internet when costs were high and speeds were low. The presumption of the availability of high-speed Internet was not a part of university teaching or research then, and therefore, professors were not integrating it into their teaching methods, or students using it at a high level. With the dramatic drop in the cost of Internet in some African countries in recent years, it would be useful to carry out further studies as fiber-based Internet and NRENs establish themselves in some countries and Internet use becomes ubiquitous. To get an idea of what that would look like, it would be useful to look at trends in ICT use in higher education in more developed economies. There is no reason to think that what is happening in Europe, the Americas, and Asia will not happen eventually in Africa.

To work or study in a modern university campus is to work in a digital ecosystem. Staff and students presume ubiquitous Internet access, through free WiFi on campus grounds, in the canteen, the library, the halls of residence, and at home, and even on the bus coming to college! How is this affecting their work? In looking at studies and papers ${ }^{48}$ on trends in $\mathrm{ICT}^{49}$ use in higher education and in discussions with academics and students, one can come up with some insight as to where this is going, filtered for what might be relevant for African higher education, under six headings:

a) Mobile and the smartphone are making technology universal. Few if anyone forecast that mobile phones would become ubiquitous in such a short time, especially in poorer countries. In fact it was the very lack of infrastructure in these countries that drove the mobile market. Smartphones are about to make a similar expansion as $3 \mathrm{G}$ is rolled out in emerging markets and the devices themselves become affordable. By 2020 it is estimated that over

\footnotetext{
${ }^{46}$ KENET Higher Education E-readiness, 2013: http://ereadiness.kenet.or.ke:8080/ereadiness/

47 Fasae and Aladeniyi. 2012. Internet Use by Students of Faculty of Science in Two Nigerian

Universities. http://digitalcommons.unl.edu/cgi/viewcontent.cgi?article=1837\&context=libphilprac

4810 Global Trends in ICT and Education. Robert Hawkins 2010. Edutech blog:

http://blogs.worldbank.org/edutech/10-global-trends-in-ict-and-education

49 NMC Horizon Report. 2015 Higher Education Edition. http://cdn.nmc.org/media/2015-nmc-

horizon-report-HE-EN.pdf
} 
80 percent of adults on earth will have a smartphone. ${ }^{50}$ And when we think 'smartphone', it is useful to understand that the central processing units (CPUs) in today's models have hundreds of times more transistors than a Pentium had in 1995 (the iPhone 6 has 625 times).

b) Bring your own device (BYOD). As students acquire smart phones, tablets, and laptops for their own work and social lives, universities see less need to provide fixed computing facilities and are concentrating instead on providing campus wide WiFi connectivity and exploring the potential of using 'Apps' over traditional software, or even web browsers. Many universities have adopted Google's Apps for Education, for example.

c) 'Blended' learning for all. Distance education in the form of correspondence courses and its digital equivalent, e-learning, has suffered from low esteem among students (and parents) and traditional universities, being considered a second-best. With the introduction of MOOCs from prestigious universities, and the popularity of e-content providers such as the Khan Academy, online learning has acquired a new respectability and elements of e-learning and MOOCs are now increasingly being incorporated into on-campus courses. No longer is there a split between online and face-to-face teaching, but instead 'everything is blended'. Universities are increasingly using digital delivery of course content and management, with every registered student having a Moodle, Blackboard, or other LMS account. Its flexibility, ease of access, and the integration of sophisticated multimedia and technologies have great appeal.

d) Educators as managers/mentors and the 'flipped classroom'. While the days of large lecture halls have not disappeared, more and more university lecturers are expected to incorporate new methodologies into their teaching, including new forms of content delivery, supporting learner interaction, and feedback, collaboration with other lecturers, the routine use of technologies, and more guiding and mentoring. In this 'flipped classroom', face time with a lecturer will be less about transfer of information and more about interaction and discussion, while the course content will be available online.

e) Availability of Open Educational Resources (OERs). In the spirit of the Creative Commons licensing of creative works, educators are increasingly creating and distributing educational content free of charge on the web. The Hewlett Foundation in 2002 defined OERs as "teaching, learning, and research resources that reside in the public domain or have been released under an intellectual property license that permits their free use and repurposing by others. Open educational resources include full courses, course materials, modules, textbooks, streaming videos, tests, software, and any other tools, materials, or techniques used to support access to knowledge." ${ }^{51}$ These can be in the form of simple video presentations on topics from the curriculum or they can be full textbooks like this recently published book from Tony Bates, Teaching in a Digital Age.$^{52}$ Many of the OERs are video-based on YouTube or in TED Talks, as is much of the content of MOOCs. As these resources are typically accessed by individual students in their own time the number of separate and simultaneous video streams being downloaded on a single campus creates a strong demand for high bandwidth connectivity.

f) Redesigning learning spaces. While the traditional lecture theatre will continue to exist, universities are looking at creating or adapting other learning spaces, especially in libraries, to accommodate innovative student learning methods. These can be formal or informal spaces where the emphasis is on group collaboration and project-based discussion, with a high usage of Internet-connected devices.

\footnotetext{
${ }^{50}$ Benedict Evens: June 2015. Mobile is Eating the World. http://ben-

evans.com/benedictevans/2015/6/19/presentation-mobile-is-eating-the-world

${ }^{51} \mathrm{http}: / / \mathrm{www}$.hewlett.org/programs/education/open-educational-resources

52 T.W. (Tony) Bates. 2015. Teaching in a Digital Age. http://opentextbc.ca/teachinginadigitalage/
} 
g) Research collaboration is a global activity. There was a time when scientists worked alone or in small local teams in their own laboratories in which they hypothesized and experimented to come up with new theories and knowledge. Rarely now is university-level research carried out in isolation from other researchers and often the collaboration is international, involving the exchange of large amounts of data and using videoconferencing for meetings. For instrumentation such as supercomputers, electron microscopes, astronomical telescopes, medical imaging, simulators, and so on, few universities or even countries, can afford the high cost of outright purchase and typically arrangements are made to lease time on these facilities and to access them through high-speed networks. The use of high-speed Internet connections is essential for collaboration with global peers and for access to high-cost instrumentation and for the exchange of large data sets.

h) The data explosion. Science is transitioning from using only two classic building blocks, theory and experimentation, to also utilizing a third, modelling and simulation, which generates massive amounts of data. This includes the human and social sciences such as economics, public health, town planning, population studies, and so on. In fact the data sets are becoming so large that researchers, even in Europe, are processing the data where the data sits and not downloading the raw data.

\section{NRENs Looking to the Future}

As ICT use grows in universities the NRENs are looking at how their 'market' is changing and how they should respond. A survey, called ASPIRE - A Study on the Prospects of the Internet for Research and Education, ${ }^{53}$ was carried out by the TERENA organization in Europe and published in 2013. The ASPIRE foresight study explored the implications of potential developments of the Internet up until 2020 and assessed their impact for the research and education networking community through questionnaires and interviews with NRENs in the GÉANT area, which includes over 40 countries. Its findings may be useful to guide emerging NRENs and it may help them leapfrog to the latest developments and services. Not all NRENs in GÉANT are as advanced as one might think and some face the same issues as emerging NRENs, such as competition from ISPs and lack of required skills to implement advanced services, which makes their experience valuable.

The main conclusions from the survey can be summarized as follows:

- NRENs need to understand that ISPs can offer many of the services demanded by clients (basic IP connectivity, email, webhosting, collaborative document production and storage) and, therefore, they need to have the flexibility and skills to customize and tailor services to client requirements, something the commercial providers are generally reluctant or unable to do.

- In a fragmented market, NRENs have the ability to aggregate demand from their own community, and because they are often funded by the government, to exploit synergies with other government departments for sharing expertise and costs, including operating at a regional level to procure services.

- If the NREN is built from the IT community within universities, there will be a level of trust there that its motives are to 'do the right thing' and are not driven by profit. The relationship between the NREN and its members will be seen as a partnership of collaboration rather than as a client and provider.

53 TERENA ASPIRE report: The Future of NRENs. September 2012.

https://www.terena.org/activities/aspire/docs/ASPIRE-future-of-nrens.pdf 
- An NREN's competitive advantage comes partly from its knowledge of the community and its needs-being a trusted part of 'the academic club'. Its combined portfolio of services is its greatest advantage; eduroam, SSO, AAI and broadband connectivity together with customized services not provided by commercial services (for example, once-off high capacity point-to-point connectivity).

- An NREN should not be afraid to collaborate and partner with commercial players to jointly deliver the services required.

- The future is mobile and NRENs need to prepare for integrating mass-mobile connectivity.

- The use of dark-fiber networks needs to be expanded to support the flexibility and agility needed to support all users.

- Clients are requesting cloud services and NRENs need to respond either with their own services or by acting as brokers for commercial services.

\section{Expanding the Community and Responding to Global Challenges}

\section{Membership}

Most NRENs prepare an AUP as part of their incorporation, which results in defining the type of institutional membership it allows and the purposes to which the network resources are put. This has traditionally been restricted to universities and research institutions, with additions including hospitals, libraries, and museums, and maybe the relevant government departments. Recently however some NRENs in Europe and the United States have begun to broaden their mission to include all kinds of knowledge and public service institutions, including colleges and schools and services like e-health, e-government, e-procurement, and culture.

Although NRENs in Africa have developed much later, or perhaps because of that, it would be useful for them to consider this wider remit in their strategy for growth. KENET, the NREN of Kenya is implementing a pilot schools initiative in Nairobi, which would be worth following. ${ }^{54}$ The KENET initiative is providing more than just connectivity to schools; it aims to provide an educational portal with the aim of improving teaching and learning in Kenyan schools. It would be wise, however, to ensure that sufficient customer support resources are in place to respond to these new clients who may not have the technical capacity of universities, so that the primary clients are not neglected.

\section{Responding to global challenges}

In the new era of big data there are needs in relation to public policy priorities like climate change, disaster management, and health pandemics that an NREN can respond to. To better position the world to meet the challenges of climate variability, environmental impact, and extreme weather events, huge amounts of data will be needed from sensors and observational facilities in the oceans, the sky, rivers, forests, and in space. There will be enormous technological advances over the next few years to better utilize the massive increase in satellite, sensor and

54 The KENET Schools Connectivity Initiative: http://schools.kenet.or.ke 
space, and remote land data. So too with the health services facing health pandemics, there is a need for the gathering, transmission, and analysis of health data on a massive scale. 
The Role and Status of National Research and Education Networks (NRENs) in Africa 


\section{Establishing an NREN}

\section{Defining the Nature and Scope of a Project}

There are no easy answers to questions regarding how an NREN is established and what it would cost, because of the number of variables involved. Firstly we need to define exactly what we mean by 'an NREN' and its relationship to campus networks. As explained in earlier chapters an NREN connects institutions, to each other nationally through a national network backbone, to other NRENs globally, and often to the commercial Internet. An NREN does not operate the local campus networks inside institutions, nor takes responsibility for their services. Whether therefore to include funding for campus networks, which could be significant, into a project to fund an NREN is a policy decision. Some NREN experts would advise against doing so, warning that it could make the project unmanageable, but funding the establishment of an NREN without considering the state of campus networks would be folly. If campus networks are nonexistent or poorly designed in a particular country, any potential NREN project there would need at least to have some plan of action for the improvement of the local connectivity. After all, the ultimate goal of establishing an NREN is not about the actual network itself but about improving connectivity for the academic community in the country, who connect to an NREN through their campus networks. This report therefore will also include a description of what cabling and equipment is required to build a campus network, with indications of approximate costs, so that the scope of funding for overall connectivity can be estimated.

The question of the cost of the national network is of a different complexity especially when considering bandwidth and access to telecom infrastructure. The market is changing rapidly and there are huge variations between countries. There are no 'generic' costs applicable from country to country, except in the case of campus networks, which do not depend on telecom providers. As the arrival of fiber networks in Africa is quite recent the market conditions vary widely from country to country, depending on the level of competition and on whether a country is landlocked or not. In addition information and communications technologies are evolving rapidly with regard to the telecom infrastructure, the signaling that runs on it, and the devices that access it.

Yet despite the difficulty in being precise about costs it is understandable that potential funders still want to know at least something about what one could paraphrase as 'what we are getting into here?' They want to know if an NREN project is 'in the ballpark' of US\$5 million, US\$10 million, or US\$50 million. The answer can be 'yes' to all three figures because an NREN can benefit from any amount of funding, and a project can be designed around a particular sum available, a case of 'cutting one's coat to suit one's cloth'. Even then a project's size and scope need to take cognizance of the NREN community's capacity to absorb the funding, the sustainability of the business model, and on the readiness of the stakeholders to take advantage of the result.

The approach taken in this chapter is to describe, on a national (NREN) and an institutional (campus network) level, the parameters of what would be regarded as an adequate ICT infrastructure for higher education, which can be compared to the reality in a given context. The result should provide guidance as to the scope and cost of a project that would fund an NREN and its linked campus networks. 


\section{National Level: The NREN}

While there is no standard model for an NREN, and local circumstances may demand a unique approach, most successful NRENs typically would have most of the following characteristics:

\section{Governance}

The NREN would:

- Be an autonomous, not-for-profit, membership-controlled, limited company, with a board elected by the key stakeholders who are primarily the academic and IT community in the member institutions, followed by government officials who would be in the minority.

- Operate under a legal framework within the educational and ICT policy of the country with a code of conduct, rights and responsibilities, as agreed with the academic community and the government of the country, set out in the company's memorandum of incorporation.

- Develop AUPs for the network as the basis of network agreements for membership and use.

- Be funded by a combination of membership fees, service charges, and government subvention on a sustainable basis.

\section{Services}

The NREN would:

- Operate a national gigabit backbone that connects campus networks to each other and to other RENs regionally and globally, and, through contracts with commercial operators, to the commodity Internet, ideally through a local Internet Exchange (IX), thus keeping local traffic local. If a local IX does not exist an NREN could help establish one.

- Begin by leasing bandwidth from a local operator, and eventually, as the NREN matures, lease and operate its own backbone links from dark-fiber and/or transmission circuit providers on an annual or IRU basis.

- Run its own NOC to monitor and report on network performance and manage incidents and fault resolution on the network.

- Ensure a security policy is implemented and maintained on the network.

- Offer discretionary services such as AAls for eduroam, edugain, and Shibboleth; videoconferencing bridging; HEMIS.

- Act as a broker for their members in procuring what are by now commodity services from commercial operators. These would include such services as commodity Internet access, e-mail services, cloud computing, web hosting, LMS, software licenses, library subscriptions, and even computing hardware. Some universities may prefer to procure these services themselves.

- Organize and hold training programs for IT staff in member institutions and if necessary include direct assistance to improve members' campus networks (resolve performance issues, assist with design and installation of wireless access, and so on). 
- Train for and implement advanced services such as Identity Management and AAIs, and possibly content mirroring, as staff skill levels allow.

\section{Membership}

- All higher and further education institutions (both public and private), research centers, teaching hospitals, large libraries, museums and similar knowledge institutions in a country would be eligible for membership.

- $\quad$ Other institutions that provide higher education services to universities.

- Other organizations with a public good focus for national development can be added as staffing levels allow, for example, schools.

\section{Funding model}

- Capital expenditure (CAPEX) would generally be funded by start-up grants and periodic capital investments from government or development partners, or capital assets could be donated by partners or national utility companies. Infrastructure such as dark fiber or bandwidth would be eligible for some public subsidy from government through UAFs or spare capacity on government networks.

- The bulk of operational expenses (OPEX) of an NREN would be financed through membership and/or service fees from member institutions and other services or projects in which it is involved.

\section{Institutional Level: Campus Networks, IT Services, and Digital Literacy}

As investments in national infrastructure are considered, campus networks of potential member institutions should be carefully examined to see whether they are capable of supporting improved access and advanced services that might be provided via an NREN. Remember that not one single student, lecturer, or researcher will be connected to the NREN; they will all be connected to the campus networks of member institutions. If these campus networks are poorly designed and implemented, then service to the campus users will be poor even if an advanced NREN is funded and built. A campus IT service would have the following characteristics:

\section{Infrastructure}

- Operate a fiber-based campus network connecting all buildings.

- Offer WiFi hotspots and access at key gathering venues for students including libraries, dining areas, and other common shared spaces. There will be a gradual increase in students having their own devices and the need for providing computer labs will decrease. The provision of strong WiFi access throughout the campus will evolve as part of a Bring Your Own Device policy, be it laptop, notebook, tablet, or smartphone.

- Equip and maintain a number of computer labs for ICT training and Internet access (although 
this function can be offered by departments and the library, and the need for it may decrease).

- Maintain a 24/7 data center with servers for e-mail, web hosting, cloud storage, administration, applications, network monitoring, and so on, with appropriate cooling systems and uninterrupted power supply (UPS). Alternatively, this function can be outsourced to commercial providers. A UPS with generator would still be required however to maintain the local area networks, even if hosting and cloud computing is outsourced.

\section{Services}

- Ensure that e-mail accounts are provided for all staff and students, most likely through commercial operators.

- Maintain software upgrades for staff and laboratories.

- Manage virus protection software and ensure networks are protected.

- Manage a cyber security system in accordance with national and international norms.

- Operate a help desk where students and staff can come to get assistance with problems.

- Offer a videoconferencing service for remote teaching and collaboration.

- Enable virtual infrastructure services to access big-data resources worldwide (such as edugain).

- Operate or negotiate a scheme with vendors for students to buy their own devices-laptops, tablets, and smart phones at competitive prices.

- Offer courses in computer applications such as PowerPoint, Word, and so on.

\section{A digitally literate community}

- Academics and students would have integrated ICTs and Internet resources into their teaching, learning, and research on a significant basis, thus creating a user base for the campus networks, and in turn the NREN and the international connectivity it provides.

- IT staff in the university would include qualified network and IT personnel capable of providing the required services in a user-friendly manner.

\section{The Enabling Environment}

The above ideal situation at the national and institutional levels requires an environment where informed opinion decides policy and agreement is possible between potential competitors. This supportive environment would exist at government and institutional levels.

\section{The government and the regulatory agencies would:}

- Be aware of the potential of NRENs to give added value services to the educational 
community beyond what an ISP can offer.

- Create a regulatory environment that perceives the NREN as providing a public good so it can be exempt from company tax and also benefit from government subsidies such as UAFs or concessionary tariffs.

- Support innovative teaching methodologies and encourage research activities at an international level.

- Encourage private sector actors who see the potential for collaboration with the NREN.

\section{The university leadership would:}

- See the benefit of shared national network services while still competing in other aspects of their educational mission.

- Be committed to contributing membership fees and service fees to an NREN.

- Actively reform the educational practice to take advantage of the new innovations.

- Promote and reward the adoption of new technologies in teaching and learning, and in administrative systems.

- Be publicly supportive of pioneering champions within the institution.

\section{Addressing the Reality}

In actual practice, it is likely that the reality in any given country will not match the vision. The divergence will vary from country to country, along the lines of the levels of the Capability Maturity Model outlined in chapter 5. An analysis of what level a country's NREN development is at, plus a query as to why it is so, will give an indication of the scale of a possible funding intervention. A program can come in at any level or baseline, most likely to relieve a development roadblock, without which further progression of the NREN is stymied. The size of a program also depends on where in the stages of development the decision makers aim to go, and if a program involves a loan, how much they want to take on.

It would be important to highlight that the key to a successful approach in a particular country would be to ensure that consultations take place with the current local champions in the universities, and in the nascent NREN if there is one, and with their experienced colleagues in the region. Even if the funding and the planning is orchestrated 'from above' it would be essential for eventual buy-in from the user community that their representatives are engaged from the beginning, and that account is taken of prior experiences and achievements.

\section{Actions to Establish an NREN}

Assuming that a project is starting at level zero in the aforementioned levels model the actions that need to be taken can be listed under a number of headings such as governance, the operation, the infrastructure, partnerships, and services. The UbuntuNet Alliance has published 
useful guidelines for their members and potential members on how to go about establishing an NREN. ${ }^{55} \mathrm{~A}$ sequence of actions to be taken can be summarized as follows:

- Getting leadership commitment and buy-in—at government AND institutional level.

- Building a membership base—core founders for a critical mass.

- Creating a governance structure-ownership, board, legal framework, AUPs, and so on.

- Establishing a secretariat—the operation, with premises, staff, equipment.

- Producing a business plan-business model, funding, fees,

- Designing and acquiring network backbone infrastructure-exploring the options of owning or leasing infrastructure or purchasing managed services.

- Addressing last mile connectivity needs.

- Engaging stakeholders-awareness raising and training in competencies.

- Developing services_-planning and implementing advanced services in addition to basic connectivity.

- Forging international partnerships-establishing connectivity to regional and global RENs.

\section{Funding}

Before any numbers are put on a proposal for funding of an NREN, it would be important to be cognizant of what is there already, what can be added at little or no cost, and what is the absorption capacity of the institutions and users for an advanced communications system. The aim would be to keep costs to a minimum while creating a service infrastructure that institutions will buy into and sustain.

It should be part of the strategy of a funded NREN project for operational costs to be selffinancing from almost the beginning of the operation based on universities paying service fees. What they are spending already on Internet access, possibly through high-cost/low-bandwidth VSATs, will give an indication of what is the lowest that they will be willing to pay an NREN in monthly service fees.

Capital funding should ideally go to procuring long lease (20 years) IRUs on fiber or lambdas, but be amortized over a five-year period, the typical length of a donor-funded project. The spare capacity that is available on the national fiber infrastructure may indicate whether concessionary rates could apply or that arrangements could be made to provide 'free' or subsidized fibers or lambdas. If the regulatory authority implements any sort of UAF then it is possible that the NREN would be eligible to benefit from it to reduce costs.

The following questions will provide answers that impinge on the scale of the funding required:

1. What are the individual universities already paying in total for their bandwidth in terms of rate (dollars per megabit per month) and quantity (how many megabits)?

2. What telecommunications data infrastructure is available in the country? Fiber? Copper?

${ }^{55}$ Martin, Duncan, Lishan Adam, Victor Kyalo, and F. F. Tusubira. 2009. UA 151: How to Set Up and Finance National Research and Education Networks. 
Microwave? VSAT? Combinations?

3. How many universities are there and where are they? This will determine not only the scale of the whole project but also the number of PoPs that would be necessary to connect all universities and the distances between them.

4. Will the NREN need an operating license?

5. What are the options, regulatory and human-capacity-wise, for a fully owned and operated network based on dark fiber leasing?

6. Are there UAFs in the country that can be tapped to buy, lease, or rent capacity?

7. Are there premises available that could be offered free or at low cost to the NREN?

8. Are there opportunities for co-funding with other development partners?

9. What is the potential for sponsorship deals with the private sector?

10. What is the capacity of the international connectivity for the country and how much does it cost?

11. Is there an Internet Exchange (IX) in the country? An IX enables local Internet traffic to stay in the country and will reduce the need and cost of international bandwidth.

12. How stable is the electrical power supply in the country?

13. How far is each university from an affordable existing fiber network? 'Last mile' connectivity (the stretch between the national backbone and an institution's premises) will be a cost on the project, and it is always more than a mile/kilometer.

14. What is the state of each potential member campus network and is it properly designed and implemented?

15. Are there bandwidth-limiting devices that will restrict the ability of a campus to utilize the new bandwidth and services?

16. Do IT personnel have the necessary skills to provide higher-level services and to support users?

17. What are the prevailing and projected bandwidth needs of the institutions?

18. What are the priorities of the institutions?

\section{Cost Headings in a Changing Environment}

As mentioned above, it is very difficult to give generic cost data on the elements of an NREN. Therefore the best that can be done is to give a list of cost headings that would need to be researched in a particular project, with the range of technical options that may be chosen, and very rough estimates of the costs involved.

The following is a list of cost headings that need to be considered: 


\section{Backbone infrastructure}

Backbone infrastructure can be the most expensive cost element for an NREN and the options are not that straightforward. As technology changes and advanced wireless broadband is rolled out in African countries some even question the need for an NREN to own a physical backbone network at all. This may be premature and there will always be the need for alternative connectivity pathways (redundancy) in cases of network failures. The options, in ascending order of capital investment, sophistication and complexity are:

a) To purchase capacity (bandwidth): For a startup NREN this option has its advantages. It has the lowest upfront costs due to little capital expenditure, but it could prove expensive on a long-term basis, as costs will rise at market rates pro rata as demand for bandwidth rises among the members. Prices are based on market rates but vary widely between countries.

b) To purchase managed services: This can be a solution when there is a lack of qualified staff to operate the telecom links. Some countries have taken this option (for example, Pakistan) where the physical network is owned and operated by a national telco and the NREN manages a VPN on that infrastructure from its own NOC.

c) To lease a lambda: This is similar to leasing dark fiber but cheaper because it is only one wavelength that is leased at a time. However, it is not that commonly available in Africa.

d) To lease dark fiber: If there is confidence that, in the longer term, full integration of ICTS and Internet will happen in higher education in a country and if professors are routinely engaging in international research partnerships, plus if there is a highly skilled IT workforce, then the lease of dark fiber is the most viable option. It involves high initial investment, but lower running costs for the capacity provided. It also makes sense in a project that is limited to about five years. By paying upfront for an IRU of twenty years for a pair or pairs of dark fibers the annual running costs for maintenance is low and additional bandwidth can be generated on demand at marginal costs. Prices for dark fiber can vary from free in certain countries where UAFS are in place to a range from US\$5,000 to US $\$ 20,000$ per kilometer.

e) Options (a) and (b) need to be paid for from operational expenses and therefore from member fees. A large part of options (c) and (d) can be a part of an upfront capital grant leading to lower operational costs. However these latter options require a more specialized workforce and give rise to higher staffing costs.

\section{Points of presence and last mile infrastructure}

Connecting individual campuses to the national backbone infrastructure will generally be through local PoPs in the major cities where there are member institutions. A PoP is the location where the NREN has equipment to serve multiple customers and they may be at customer premises or co-located at an ISP's PoP. The size and cost of a PoP can vary from a simple rack with routers costing approximately US\$5,000 to a sophisticated facility with a videoconferencing Multipoint Control Unit, servers, and other equipment costing up to US\$500,000.

For universities outside of these urban centers the connectivity options depend on the extent of fiber in the country and whether universities are situated in remote areas. It may be necessary for the NREN to build its own physical infrastructure from the backbone if the operator is not willing to do so. The connection may involve the laying of fiber optic cables or installing microwave links. Depending on policy, this task may be the responsibility of the individual institution, or it may be part of the portfolio of the NREN. 


\section{International connectivity}

The best option for international connectivity for African NRENs is to connect to a regional network, when each is fully operational, as a way to reach global networks. This is how some of the NRENs of Eastern and Southern Africa do it. The AfricaConnect2 project offers this option for West and Central Africa in the next four years. A co-payment of approximately €250,000$€ 280,000$ gets a country NREN entry to the international REN infrastructure and that includes some discounted bandwidth.

\section{Premises}

It would be worth investigating whether a ministry, a university, or other agency could donate premises, be it administrative offices or specialized data center accommodation (with their added heating, ventilation and air conditioning (HVAC) requirements). For sizeable data centers the utility fees can be the biggest component of costs.

\section{Equipment}

Routers, switches, servers, computers, racks, cabling, generators, and so on.

\section{Staff}

CEO, CTO, network engineers, trainers, accounting and finance staff, communication officer. The numbers of staff required depend on the services offered and the size of the membership, but it could range from 3 to 10 staff at start-up. Even in advanced European countries, the number of fulltime equivalent staff in NRENs varies from a low of eight (Austria) to a high of 180 (United Kingdom). ${ }^{56}$ It is important for NREN engineers to be experimenters because of the fast moving nature of technology. It is also important for NREN as an organization to retain the investment made in training. Thus the compensation package needs to be competitive while the NREN also needs to work in the context of the financial reality of the university system of a country. The upper range of compensation offered to full/associate/assistant professors (based on years of service and responsibility) in the discipline can be a benchmark for many countries. The CEO should be a respected leader in the field at the level of a university professor/department head and a person with social capital who can speak with credibility with university and government leadership.

\section{Training}

There is a continuous need for initial and continuing education of NREN staff and IT personnel in universities. It is a good idea for NRENs to have training facilities available locally. This services need to be overprovisioned depending on the severity of the capacity needs in a country.

\footnotetext{
56 TERENA Compendium of National Research and Education Networks in Europe 2014, p. 80
} https://www.terena.org/publications/files/Compendium-2014.pdf 


\section{Promotions}

Communications with stakeholders and end users.

\section{Campus Network}

As mentioned above Campus Networks are generally not the responsibility of an NREN, but without them an NREN has no meaning. It is therefore useful to include here what is involved in building campus networks and what the costs might be. The lists below presume that one is starting from scratch and implementing a complete build-out. Account should be taken of what elements of a campus network already exist and to what extent a project should fund the full build. Also note that this summary does not include computers or computer labs-in a higher education project with an ICT component this is something that may need to be funded as well. The equipment and related costs below are divided into (a) overall campus costs (cabling and equipment) and (b) what is required for each building.

\section{Campus-wide cabling infrastructure}

This includes fiber running from the central/core building to each of the served buildings. The distance to the buildings and whether the fiber is run aerially or underground will dramatically affect how much this will cost. Aerial fiber strung on existing poles will be cheapest. Underground installations will vary depending on the difficulty of digging and how much rock is present. Secondly, cabling needs to be installed inside each building. How much will depend on the nature of the building and how extensive the run needs to be. Typically this would extend to each office, classroom and laboratory, and also to each WiFi access point. Costs would be in the order of:

a) Aerial fiber installation: US\$10 per meter

b) Underground fiber installation: US\$100 per meter

c) Inside cable installation per office/classroom/wireless access point: US\$300 per outlet

\section{Network equipment}

Central core network equipment for a campus network is relatively fixed no matter the size of the campus. Every campus will need a border router, a core router, 3 to 6 servers (for assigning IP addresses, file storage, and network monitoring), and a battery backup unit. A generator would be useful but not essential if there is an efficient battery back-up power source. Depending on the size of the campus, the costs are approximately as follows:

\begin{tabular}{|l|c|c|}
\hline \multicolumn{1}{|c|}{ Item } & Small campus (US\$) & Large Campus (US\$) \\
\hline Border router & 10,000 & 50,000 \\
\hline Core router & 20,000 & 50,000 \\
\hline Servers (at US\$4,000 each) & 12,000 & 24,000 \\
\hline Central battery backed power & 10,000 & 20,000 \\
\hline Total & 52,000 & 144,000 \\
\hline
\end{tabular}

Overall, central equipment costs would amount to approximately US $\$ 50,000$ for a small campus and US $\$ 150,000$ for a larger one. 


\section{Buildings}

Cabling and equipment costs per building (from medium- to large-sized buildings) are listed below based on typical scenarios:

\begin{tabular}{|l|c|c|}
\hline \multicolumn{1}{|c|}{ Scenario } & $\begin{array}{c}\text { Medium Building } \\
\text { (US\$) }\end{array}$ & $\begin{array}{c}\text { Large Building } \\
\text { (US\$) }\end{array}$ \\
\hline $\begin{array}{l}\text { Fiber cabling underground to buildings 400-800 } \\
\text { meters from central building }\end{array}$ & 40,000 & 80,000 \\
\hline Internal cabling to 40-80 locations & 12,000 & 24,000 \\
\hline Switches (2-5 at US\$5,000 each) & 10,000 & 25,000 \\
\hline 15 to 30 WiFi access points (at US\$500 each) & 7,500 & 15,000 \\
\hline Total & $\mathbf{5 9 , 5 0 0}$ & $\mathbf{1 4 4 , 0 0 0}$ \\
\hline
\end{tabular}

To put this data into perspective, a relatively small campus of say, six large buildings and four smaller buildings, total costs for a campus network, taking round figures, would be approximately US\$1,200,000 in total comprising:

a) Central costs: US $\$ 52,000$

b) Large buildings X 6: US\$900,000

c) Medium buildings X 4: US\$240,000 
The Role and Status of National Research and Education Networks (NRENs) in Africa 


\section{Conclusion and Recommendations}

\section{ICTs Can Contribute to the Quality of Higher Education in Africa}

In a digital age, when very soon almost every adult in Africa will carry around a multimedia computing device connected to the Internet, it would be natural that governments, their development partners, and the private sector would explore how this revolution can address some of the challenges of education in their countries. In March 2015, over five hundred delegates from Africa and beyond gathered in Dakar, Senegal, for the first summit on Africa's higher education. The summit was a forum for defining an agenda for the reform of the African higher education sector, and it ended with a Declaration and Action Plan on revitalizing higher education in Africa. The Declaration began with a stark analysis of the challenges facing the sector, "The African higher education sector has grown rapidly since independence, facilitated by rising population and growing demand, expansion of African economies and need for skilled labor, and establishment of a private higher education sector. Despite this growth, the sector faces serious challenges manifested in poor quality, inadequate infrastructures, outdated pedagogies, low levels of funding, scholarly productivity, and global competitiveness." 57

In its list of actions to remedy these ills the role of ICTs in innovative teaching methods and research plays a significant part. To quote from the Declaration:

"2.2.4. Higher education institutes shall embrace pedagogies that emphasize participation, creativity, invention, innovative citizenship and new technologies for teaching and learning."

"3.2.1 Diversifying modes of delivery: In addition to expansion through building brand-new public and private institutions as well as upgrading existing ones, higher education institutions need to deploy high quality distance and online education."

"4.1.3 Improve the quality of instruction by employing academic staff with terminal degrees and providing training and development workshops for every instructor in the most effective pedagogical practices of teaching and learning including effective uses of new information and instructional technologies.

"4.1.4 Improve the quality and quantity of research by increasing funding, providing adequate and modern research facilities and infrastructure, and rewarding research excellence."

"4.1.7 By 2063, African countries shall take the lead in using technology to drive education."

"5.3 It is imperative to promote intra-continental and inter-continental research and STI partnerships and collaborations."

"5.3.3 Africa is the only habitable continent without a major multidisciplinary scientific instrumentation, like the synchrotron light source, while thousands of African scientists travel to use facilities abroad."

${ }^{57}$ Declaration from African Higher Education Summit - Revitalizing Higher Education for Africa's

Future. March 12, 2015. http://summit.trustafrica.org/wp-content/uploads/2015/07/Executive-

SummaryFINAL.pdf 
"6.3 The quality of teaching must be improved by encouraging inquiry driven pedagogical approaches and independent learning, early introduction of students to research, the use of technology, and by balancing enrolment growth with existing institutional capacities."

"8.1.6 Invest in technological infrastructure to facilitate distance learning and collaborations between African institutions and institutions served by the African academic diaspora."

As demonstrated in this report, the achievement of these objectives would require highspeed Internet connectivity and related services that are dedicated to the needs of the academic community. Global practice shows that the optimum method for doing this is to support the establishment of a functioning and sustainable NREN in each country and to connect it to regional and global networks.

\section{Recommendations to Governments}

Governments, even in the most liberalized countries, generally take a responsibility for the organization of, and most of the funding for, essential infrastructure such as roads, bridges, power networks, and so on. This infrastructure is regarded as too important to be left to the vagaries of the market, even if some of it is provided by the private sector. In the same way, Internet connectivity can be said to be of strategic importance for a country's development these days, especially in the areas of education, public health, and government. An NREN can be seen as strategically important as the agency that acts for the education sector in its connectivity needs. In that capacity, it would negotiate with commercial operators for the services that they can best deliver and retain responsibility for specialized services unique to the academic community. The government's role would be to:

- Ensure liberal regulatory policy that stimulates the market for broadband services while recognizing the public good nature of the Internet for education and health.

- Legislate accordingly to enable it to subsidize in part the operations of an NREN.

- Support the establishment of an NREN and its ongoing operations as an independent agency with its own board of directors, drawn mainly from the institutions it serves.

- Allow for duty-free importation of equipment for use in NREN and campus network development.

- If necessary seek, on behalf of the NREN, donor funding for start-up and early operating costs and for occasional capital investments.

- Provide operator's licenses to the NREN in accordance with agreed AUPs. These policies would ensure that the NREN is not a competitor to the private sector in the provision of commodity Internet to the public.

- Promote the adoption of ICTs and new technologies in the education sector where appropriate. 


\section{Recommendations to Private Sector and Telecom Sector}

Commercial technology and connectivity providers with vision will see the emergence of an NREN as an opportunity for collaboration and a potential boost, and not a threat, to their business. An NREN can coordinate the development of a whole new market for services, for Internet connectivity, software sales, and equipment and maintenance contracts. As broker, the NREN is a buyer with a large purse. Hence the private sector could follow the example of companies such as Cisco and Google and support the emergence of NRENs with financial or in-kind contributions and discounts.

In the longer term, by building a client base from the students who graduate as digital users higher education has the potential to transform the telecom sector. Graduates will be the future business owners, executives, and decision makers in the country and therefore the private sector should see an NREN as a partner and not just a client.

\section{Recommendations to Higher Education Institutions}

If an NREN is to be successful it requires a vision from the leadership of the higher education institutions to see the benefits of collaboration for their connectivity needs. It is usual for universities in the same country to see others as competitors, competing for funding, for students, and for status. Yet just as a city of competing businesses see the benefits of forming a chamber of commerce, an enlightened academic community will see the benefits of forming a consortium for shared connectivity and common services. The partnership needs to be strong however, as some ISPs can engage in predatory actions to break the unity of the consortium with special low cost deals to individual institutions. Without a critical mass of member institutions an NREN can never be sustainable.

Besides collaborating on the formation of an NREN, the university leaders need to look to the readiness of their own institutions to benefit from the increased connectivity. They need to invest in, or seek funds to invest in:

- An adequate and well-staffed campus network infrastructure and computing services.

- The digital literacy of the academics, the students, and the administrators to transform their teaching and research, their learning and their administrative functions, respectively.

\section{Recommendations to NRENs}

While the market for Internet services continues to be ever more competitive in African countries, competing on price alone should not be the NRENs' major or unique objective. Their relevance to their member universities will be based on their ability to provide more and more relevant services, dedicated to education and research, which itself is increasingly global and collaborative. Hence, it is important that NRENs invest in capacity-building programs for their staff to be in a position to offer those advanced services. 


\section{Recommendations to Development Partners}

The efforts and achievements of African countries in establishing NRENS have benefited from considerable support from development partners such as the AAU, the EU, IDRC (Canada), NSRC and NSF (United States), SIDA (Sweden), Nuffic (The Netherlands), European NRENs, and the Bank. The partnerships have built on respective synergies resulting in admirable advances in the development of NRENs, regional networks, and global connectivity, especially in Eastern and Southern Africa through the multi-partner AfricaConnect project.

The Bank has been engaged in higher education in Sub-Saharan Africa for a number of years. The Bank's efforts focused on quality improvements in teaching, learning, and research, support of the establishment of the essential connectivity, and content development. Indeed, a number of Bank projects have already part funded ICT and NREN projects in Nigeria, Mozambique, Kenya, Senegal, and Somalia.

Development partners can support NREN development through:

a) their advisory services to governments on policy;

b) convening or supporting knowledge exchanges with global experience;

c) capacity-building and training programs; and

d) funding of projects (in ICT, education, and capacity building).

\section{Advisory services}

Emerging NRENs find it challenging to persuade government and university management of the value of and need for establishing a dedicated network and organization to address the connectivity needs of higher education. The convening power and the credibility of development partners means that they can play a powerful advocacy role in this area. It could be their advice on policy in the telecom regulatory area regarding the public good nature of NRENs, or in advising on the role that ICT and Internet connectivity could play in the improvement of the quality of research, teaching and learning at the university level. An early input could be to advise the emerging NREN on developing a consortium and a business model for a sustainable service.

\section{Knowledge exchanges}

Knowledge exchanges on a South-South basis have proven very valuable in raising awareness among decision makers on the importance and nature of NRENs. These can be in the form of study visits to other NRENs in a region or virtual meetings and presentations. A successful example of knowledge exchanges for raising awareness of NRENs was the SERENE project in 2012, funded by a multi-donor trust fund. ${ }^{58}$ By combining a series of videoconferences and an online discussion with study visits to four countries it was possible to inspire administrators from Afghanistan, Bangladesh, Bhutan, and Nepal to initiate or support projects to establish NRENs in their respective countries, two of which are now being financially supported by the Bank (Afghanistan and Bangladesh). On a smaller scale simply attending the annual meetings of the three regional REN associations in Africa would do much to raise awareness and provide stimulus for these key people in government and in the universities.

${ }^{58}$ Report on South-South Exchange of Research and Education Network Experience (SERENE)

2012: http://wbi.worldbank.org/sske/story/learning-build-national-research-and-education-

networks-nrens-south-asia 


\section{Capacity building}

The various Internet and NREN associations in Africa such as the AfNOG, African Network Information Centre (the Internet Numbers Registry for Africa), AfREN, ASREN, UbuntuNet Alliance, and WACREN have been offering training programs to emerging NRENs for a number of years. They have been helped enormously by the work of the NSRC of the University of Oregon which is part funded by the NSF. Various funding initiatives of the EU and Commission have capacity-building elements, described in the Annexes II and III. A number of European NRENs have contributed expertise and personnel in these capacity-building programs as well.

It is recommended that other development partners contribute to and coordinate with these efforts at an appropriate level.

\section{Direct financing}

Development partners already support quality improvements in higher education for teaching, learning, and research. It would be a natural progression to support the establishment of the essential connectivity required for these activities to be on a par with international peers in a digital age. Therefore, in almost every higher education or research project, be it for improving the quality of teaching and learning, developing learning content, stimulating research, or establishing centers of excellence, cognizance must be taken of the state of connectivity in the sector and remedial measures added to the project if found wanting. There is a case too for projects that would be solely concerned with the establishment of NRENs in their own right. As has been demonstrated in this report, NRENs are complex and the making of a successful one requires the dedication of significant resources and project management.

Establishing a sustainable NREN requires a period of time that may be beyond the period of typical donor projects. An NREN is an ecosystem and a way of doing business, not simply an infrastructure build that can fit in a five-year project. Nurturing a consensus among stakeholders (university vice chancellors, telecom operators, and relevant ministries), establishing technical capacity (both academic and in IT), and campus infrastructure in universities to be able to avail of services, plus building of the actual NREN, a nationwide network with skilled staff and business practices, requires time and multi-sector involvement. It would be prudent therefore to plan financial support for the establishment of an NREN over a multi-project program rather than in a 'big bang' fast track project.

\section{Conclusion}

Since the arrival of the latest submarine fiber optic cables to the African shores in the last decade, there has been a well-coordinated effort to establish national and regional consortia for research and education networking. This has resulted in some early NRENs being established and some international and intra-regional and global connectivity being in place. The progress in the last decade has been impressive with eighteen countries on the continent having operational NRENs. In addition, there are three regional associations that are collaborating with each other and with international partners to implement a pan-African Research and Education Network. Yet there is much work to be done. The advice to development partners who wish to support these developments is to:

- Engage with the actors and their partners that are already heavily involved. On a regional basis in Africa these would be ASREN, WACREN, and the UbuntuNet Alliance, and the partners involved in the AfricaConnect2 program. 
- Integrate their support with the programs that are currently in place. Remembering that 'one size does not fit all', support to individual countries must begin with an assessment of the level of maturity of the NREN and of the telecom infrastructure and market in that country.

- Contribute where there are gaps in the various programs, and in accordance with their strengths and with the needs of the stakeholders.

- Contribute at a level that would be sustainable after the end of the project. 


\section{Annex A. Country by Country African NREN Status}

\section{Eastern and Southern Africa - Area of the UbuntuNet Alliance}

\section{UbuntuNet Alliance}

Location: Onions Office Complex, Area 4, Lilongwe

Address: P.O. Box 2550, Lilongwe, Malawi.

Contacts: CEO: Pascal Hoba

CTO: Joseph Kimali (Nairobi)

Finance and Administration: Tiwonge Banda

Tel: +265 1754535 (Mobile: +265 997158641)

e-mail: info@ubuntunet.net

\section{Angola}

\begin{tabular}{|l|l|}
\hline NREN & None \\
\hline Operational status & Non-operational. Level 1 development \\
\hline Date established & - \\
\hline Address & - \\
\hline Contact & - \\
\hline Comments & - \\
\hline
\end{tabular}

\section{Botswana}

\begin{tabular}{|l|l|}
\hline NREN & None \\
\hline Operational status & Non-operational. Level 2 development \\
\hline Date established & - \\
\hline Address & - \\
\hline Contact & Simon Coles scoles@gov.bw \\
\hline Comments & - \\
\hline
\end{tabular}

\section{Burundi}

\begin{tabular}{|l|l|}
\hline NREN & BERNET \\
\hline Operational status & Operational internally. Level 4 development \\
\hline Date established & November 2014 \\
\hline Address & BERNET, c/o University of Burundi P.O. Box 1550 Bujumbura \\
\hline Contact & CEO: Dr. Grégoire Njejimana Tel: + 257 77751877 \\
\hline Governance & $\begin{array}{l}\text { Executive Committee, chaired by the Rector of the University of } \\
\text { Burundi: Dr. Gaspard BANYANKIMBONA } \\
\text { gaspard.banyankimbona@ub.edu.bi }\end{array}$ \\
\hline
\end{tabular}




\begin{tabular}{|c|c|c|c|c|}
\hline $\begin{array}{l}\text { Relationship to } \\
\text { government }\end{array}$ & \multicolumn{4}{|c|}{$\begin{array}{l}\text { Supported by government but independently managed as non-profit } \\
\text { organization }\end{array}$} \\
\hline Funding sources & \multicolumn{4}{|c|}{ Members, Government (World Bank RECIP2) } \\
\hline Operating Budget & \multicolumn{4}{|c|}{ None } \\
\hline Staffing FTEs & \multicolumn{4}{|c|}{ Voluntary executive committee } \\
\hline $\begin{array}{l}\text { Network backbone } \\
\text { capacity }\end{array}$ & \multicolumn{4}{|c|}{ Information not available } \\
\hline $\begin{array}{l}\text { International REN } \\
\text { connectivity }\end{array}$ & \multicolumn{4}{|l|}{ No connection } \\
\hline Services & \multicolumn{4}{|c|}{ Internet connection to members } \\
\hline Middleware services & \multicolumn{4}{|c|}{ None } \\
\hline Comments & \multicolumn{4}{|l|}{-} \\
\hline Membership & \multicolumn{4}{|c|}{14 Institutions connected } \\
\hline Type of Institution & $\begin{array}{l}\text { Allowed to serve } \\
\text { this category of } \\
\text { institution? }\end{array}$ & $\begin{array}{l}\text { Number of } \\
\text { institutions } \\
\text { connected }\end{array}$ & $\begin{array}{c}\text { Range of } \\
\text { bandwidth } \\
\text { provided }\end{array}$ & $\begin{array}{l}\text { Market } \\
\text { Share (\%) }\end{array}$ \\
\hline Universities & Public and Private & 13 & 38 & \\
\hline $\begin{array}{l}\text { Teacher training } \\
\text { colleges }\end{array}$ & - & - & - & - \\
\hline $\begin{array}{l}\text { Ecole Normale } \\
\text { Supérieure }\end{array}$ & Yes & 1 & 2 & - \\
\hline Research institutes & - & - & - & - \\
\hline Secondary schools & - & - & - & - \\
\hline Primary schools & - & - & - & - \\
\hline $\begin{array}{l}\text { Libraries, museums, } \\
\text { cultural institutions }\end{array}$ & - & - & - & - \\
\hline $\begin{array}{l}\text { Hospitals (other than } \\
\text { university hospitals) }\end{array}$ & - & - & - & - \\
\hline $\begin{array}{l}\text { Government } \\
\text { departments }\end{array}$ & - & - & - & - \\
\hline $\begin{array}{l}\text { For-profit } \\
\text { organizations }\end{array}$ & - & - & - & - \\
\hline $\begin{array}{l}\text { International } \\
\text { organizations }\end{array}$ & - & - & - & - \\
\hline
\end{tabular}

\section{Comoros}

\begin{tabular}{|l|l|}
\hline NREN & None \\
\hline Operational status & Level 0 development \\
\hline Date established & - \\
\hline Address & - \\
\hline Contact & - \\
\hline
\end{tabular}

\section{Democratic Republic of Congo (DRC)}

\begin{tabular}{|l|l|}
\hline NREN & Eb@le - www.ebale.cd \\
\hline Operational status & Operational. Level 4.5 development \\
\hline Date established & - \\
\hline Address & Avenue de la Democratie 44, Kinshasa-Gombe \\
& B.P. 14898, Kinshasa 1 \\
\hline Contact & CEO: Prof. Dibungi Kalenda \\
\hline
\end{tabular}




\begin{tabular}{|c|c|c|c|c|}
\hline Governance & \multicolumn{4}{|l|}{ - } \\
\hline $\begin{array}{l}\text { Relationship to } \\
\text { government }\end{array}$ & \multicolumn{4}{|l|}{ Government funded } \\
\hline Funding sources & \multicolumn{4}{|l|}{ - } \\
\hline $\begin{array}{l}\text { Network backbone } \\
\text { capacity }\end{array}$ & \multicolumn{4}{|l|}{-} \\
\hline $\begin{array}{l}\text { International REN } \\
\text { connectivity }\end{array}$ & \multicolumn{4}{|c|}{ Pending, to UbuntuNet Alliance through Cape Town } \\
\hline Services & \multicolumn{4}{|l|}{ - } \\
\hline Middleware services & \multicolumn{4}{|c|}{-} \\
\hline Research activity & \multicolumn{4}{|c|}{$\begin{array}{l}\text { Eb@leGrid - NAPRECA - Natural Product Research Network for } \\
\text { Eastern and Central Africa } \\
\text { Eb@lé-Santé (with Belgian universities) }\end{array}$} \\
\hline Comments & \\
\hline Membership & & \multicolumn{3}{|c|}{ Not known } \\
\hline Type of Institution & $\begin{array}{l}\text { Allowed to serve } \\
\text { this category of } \\
\text { institution? }\end{array}$ & $\begin{array}{l}\text { Number of } \\
\text { institutions } \\
\text { connected }\end{array}$ & $\begin{array}{c}\text { Range of } \\
\text { bandwidth } \\
\text { provided }\end{array}$ & $\begin{array}{c}\text { Market } \\
\text { Share (\%) }\end{array}$ \\
\hline Universities & - & - & - & - \\
\hline $\begin{array}{l}\text { Teacher training } \\
\text { colleges }\end{array}$ & - & - & - & - \\
\hline $\begin{array}{l}\text { Colleges of further } \\
\text { education }\end{array}$ & - & - & - & - \\
\hline Research institutes & - & - & - & - \\
\hline Secondary schools & - & - & - & - \\
\hline Primary schools & - & - & - & - \\
\hline $\begin{array}{l}\text { Libraries, museums, } \\
\text { cultural institutions }\end{array}$ & - & - & - & - \\
\hline $\begin{array}{l}\text { Hospitals (other than } \\
\text { university hospitals) }\end{array}$ & - & - & - & - \\
\hline $\begin{array}{l}\text { Government } \\
\text { departments }\end{array}$ & - & - & - & - \\
\hline $\begin{array}{l}\text { For-profit } \\
\text { organizations }\end{array}$ & - & - & - & - \\
\hline $\begin{array}{l}\text { International } \\
\text { organizations }\end{array}$ & - & - & - & - \\
\hline
\end{tabular}

\section{Eritrea}

\begin{tabular}{|l|l|}
\hline NREN & None \\
\hline Operational status & Non-operational. Level 1 development \\
\hline Date established & - \\
\hline Address & - \\
\hline Contact & - \\
\hline Comments & - \\
\hline
\end{tabular}




\section{Ethiopia}

\begin{tabular}{|c|c|c|c|c|}
\hline NREN & \multicolumn{4}{|c|}{ EthERNet - www.ethernet.edu.et (under construction) } \\
\hline Operational status & \multicolumn{4}{|c|}{ Operational. Level 4.5 development } \\
\hline Date established & \multicolumn{4}{|c|}{2001} \\
\hline Address & \multicolumn{4}{|c|}{ EthERNet Data Center, near to National Museum, Addis Ababa } \\
\hline Contact & \multicolumn{4}{|c|}{ CEO: Zelalem Assefa, Telephone: +251930099231 } \\
\hline Governance & \multicolumn{4}{|c|}{ Report to State Minister for Higher Education } \\
\hline $\begin{array}{l}\text { Relationship to } \\
\text { government }\end{array}$ & \multicolumn{4}{|c|}{ Part of Ministry of Education } \\
\hline Funding sources & \multicolumn{4}{|c|}{ Government - 100\% } \\
\hline Operating budget & \multicolumn{4}{|c|}{ US\$12 million for 2015} \\
\hline Staffing (FTEs) & \multicolumn{4}{|c|}{12 centrally and 100 in universities } \\
\hline $\begin{array}{l}\text { Network backbone } \\
\text { capacity }\end{array}$ & \multicolumn{4}{|c|}{$10 \mathrm{Gbps}$} \\
\hline $\begin{array}{l}\text { International REN } \\
\text { connectivity }\end{array}$ & \multicolumn{4}{|l|}{ None } \\
\hline Services & \multicolumn{4}{|c|}{$\begin{array}{l}\text { Digital library, video conferencing (Polycom bridging), planning for this } \\
\text { year: web hosting, email hosting, collaboration }\end{array}$} \\
\hline \multicolumn{5}{|c|}{ 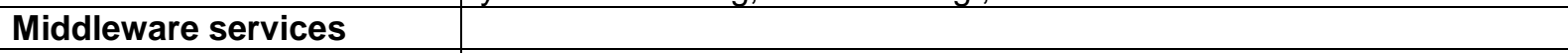 } \\
\hline \multirow{2}{*}{\multicolumn{5}{|c|}{$\begin{array}{l}\text { Comments } \\
\text { Membership }\end{array}$}} \\
\hline & & & & \\
\hline Type of Institution & $\begin{array}{l}\text { Allowed to serve } \\
\text { this category of } \\
\text { institution? }\end{array}$ & $\begin{array}{l}\text { Number of } \\
\text { institutions } \\
\text { connected }\end{array}$ & $\begin{array}{c}\text { Range of } \\
\text { bandwidth } \\
\text { provided }\end{array}$ & $\begin{array}{c}\text { Market } \\
\text { Share (\%) }\end{array}$ \\
\hline Universities & Yes & 36 public & $\begin{array}{l}100 \\
\text { Mbps }\end{array}$ & 100 \\
\hline $\begin{array}{l}\text { Teacher training } \\
\text { colleges }\end{array}$ & Yes & $\begin{array}{l}\text { (34 - in } \\
\text { universiti } \\
\text { es }\end{array}$ & - & - \\
\hline $\begin{array}{l}\text { Colleges of further } \\
\text { education }\end{array}$ & - & - & - & - \\
\hline Research institutes & - & - & - & - \\
\hline Secondary schools & - & - & - & - \\
\hline Primary schools & - & - & - & - \\
\hline $\begin{array}{l}\text { Libraries, museums, } \\
\text { cultural institutions }\end{array}$ & - & - & - & - \\
\hline $\begin{array}{l}\text { Hospitals (other than } \\
\text { university hospitals) }\end{array}$ & - & - & - & - \\
\hline $\begin{array}{l}\text { Government } \\
\text { departments }\end{array}$ & - & - & - & - \\
\hline $\begin{array}{l}\text { For-profit } \\
\text { organizations }\end{array}$ & - & - & - & - \\
\hline $\begin{array}{l}\text { International } \\
\text { organizations }\end{array}$ & - & - & - & - \\
\hline
\end{tabular}




\section{Kenya}

\begin{tabular}{|c|c|c|c|c|}
\hline NREN & \multicolumn{4}{|c|}{ KENET - www.kenet.or.ke } \\
\hline Operational status & \multicolumn{4}{|c|}{ Fully operational with International REN connectivity. Level 6} \\
\hline Date established & \multicolumn{4}{|c|}{1999} \\
\hline Address & \multicolumn{4}{|c|}{ University of Nairobi, Jomo Kenyatta Memorial Library } \\
\hline Contact & \multicolumn{4}{|c|}{ Meoli Kashorda; mkashorda@kenet.or.ke; +254 733611038} \\
\hline Governance & \multicolumn{4}{|c|}{ Separate legal entity registered as a Trust } \\
\hline $\begin{array}{l}\text { Relationship to } \\
\text { government }\end{array}$ & \multicolumn{4}{|c|}{ Indirect (some board members from public universities) } \\
\hline Funding sources & \multicolumn{4}{|c|}{$\begin{array}{l}\text { Members (95\%), Government (3\%), Google sponsorship (1\%). World } \\
\text { Bank (KTCIP): US } \$ 11.2 \text { million. Google: US } \$ 200,000 \text {, USAID: US } \$ 1.1 \\
\text { million, Rockefeller and Ford Foundations: US } \$ 500,000 \text {. }\end{array}$} \\
\hline Operating budget & \multicolumn{4}{|c|}{ 2014: US\$7.2 million, 2015: US\$9.9 million } \\
\hline Staffing (FTEs) & \multicolumn{4}{|c|}{35} \\
\hline $\begin{array}{l}\text { Network backbone } \\
\text { capacity }\end{array}$ & \multicolumn{4}{|c|}{10 Gbps backbone leased line } \\
\hline $\begin{array}{l}\text { International REN } \\
\text { connectivity }\end{array}$ & \multicolumn{4}{|c|}{$\begin{array}{l}\text { SEACOM: STM-1 Nairobi<>London } \\
\text { SEACOM: } 1 \text { X STM-16 (2.5Gbps) Nairobi<>Amsterdam } \\
\text { SEACOM: } 1 \text { X STM-4 (620Mbps) Nairobi<> Amsterdam } \\
\text { TEAMs/SWM4: } 2 \text { X STM-4 (1.24Gbps) Nairobi<>London, GÉANT } \\
\text { TEAMS: } 1 \text { X STM-4 (620Mbps) Nairobi<> Fujira (UAE) } \\
\text { AfricaConnect: } 150 \text { Mbps Nairobi<> J'Burg }\end{array}$} \\
\hline Services & \multicolumn{4}{|c|}{$\begin{array}{l}\text { e-learning (Moodle), storage, virtualization, p-to-p circuits, data } \\
\text { recovery, Akamai and Google PoP peering, Google cache, mirroring, } \\
\text { cloud services, full centralized videoconferencing service ( } 7 \text { members } \\
\text { have VC classroom). }\end{array}$} \\
\hline Middleware services & \multicolumn{4}{|c|}{$\begin{array}{l}\text { Security, spam measures (DDOS), anti-spoofing, mitigation, formal } \\
\text { security policy. } \\
\text { AAI: SSO, Africa Science Grid gateway, eduroam, digital certificates. }\end{array}$} \\
\hline Comments & \multicolumn{4}{|c|}{$\begin{array}{l}\text { Schools connectivity initiative: } 50 \text { schools in } 6 \text { months. } \\
\text { Developments for 2015/2016: } \\
\text { Lighting leased dark fiber in Nairobi area - } 250 \mathrm{~km} \text {. Lighting leased } \\
\text { from National Fiber Optic Backbone Infrastructure (NOFBI) - } 500 \mathrm{~km} \text {. } \\
\text { Connecting } 200 \text { schools, } 150 \text { in Nairobi. Upgrade of core network in } \\
\text { Nairobi }\end{array}$} \\
\hline Membership & \multicolumn{4}{|l|}{ - } \\
\hline Type of Institution & $\begin{array}{l}\text { Allowed to serve } \\
\text { this category of } \\
\text { institution? }\end{array}$ & $\begin{array}{l}\text { Number of } \\
\text { institutions } \\
\text { connected }\end{array}$ & $\begin{array}{c}\text { Range of } \\
\text { bandwidth } \\
\text { provided }\end{array}$ & $\begin{array}{c}\text { Market } \\
\text { Share (\%) }\end{array}$ \\
\hline Universities & Yes & 57 & - & 88 \\
\hline $\begin{array}{l}\text { Teacher training } \\
\text { colleges }\end{array}$ & Yes & 2 & - & 10 \\
\hline $\begin{array}{l}\text { Colleges of further } \\
\text { education }\end{array}$ & Yes & 10 & - & 10 \\
\hline Research institutes & Yes & 11 & - & 70 \\
\hline Secondary schools & $\begin{array}{l}\text { Yes - school's } \\
\text { initiative }\end{array}$ & $\begin{array}{l}88 \text { in } \\
\text { Nairobi }\end{array}$ & - & - \\
\hline Primary schools & Yes & Nairobi & - & - \\
\hline $\begin{array}{l}\text { Libraries, museums, } \\
\text { cultural institutions }\end{array}$ & Yes & & - & - \\
\hline
\end{tabular}




\begin{tabular}{|l|l|l|l|l|}
\hline $\begin{array}{l}\text { Hospitals (other than } \\
\text { university hospitals) }\end{array}$ & Yes & Planned & - & - \\
\hline $\begin{array}{l}\text { Government } \\
\text { departments }\end{array}$ & Yes & $9+$ & - & - \\
\hline $\begin{array}{l}\text { For-profit } \\
\text { organizations }\end{array}$ & No & - & - & - \\
\hline $\begin{array}{l}\text { International } \\
\text { organizations }\end{array}$ & Yes & 2 & - & - \\
\hline
\end{tabular}

Lesotho
\begin{tabular}{|l|l|}
\hline NREN & None \\
\hline Operational status & University once, but no longer; served by TENET \\
\hline Date established & - \\
\hline Address & - \\
\hline Contact & Mahlomola Ntene mp.ntene@nul.Is \\
\hline Comments & Did a deal with local Telco for commodity Internet \\
\hline
\end{tabular}

\begin{tabular}{|c|c|c|c|c|}
\hline NREN & \multicolumn{4}{|c|}{ iRENALA - http://www.irenala.edu.mg } \\
\hline Operational status & \multicolumn{4}{|c|}{ Operational. Level 4 development } \\
\hline Date established & \multicolumn{4}{|c|}{-} \\
\hline Address & \multicolumn{4}{|c|}{$\begin{array}{l}\text { Porte } 201 \text { - Ministère de l'Enseignement Supérieur et de la Recherche } \\
\text { Scientifique - Fiadanana, Antananarivo } 101\end{array}$} \\
\hline Contact & \multicolumn{4}{|c|}{ contact@irenala.edu.mg } \\
\hline Governance & \multicolumn{4}{|c|}{$\begin{array}{l}\text { Non-Profit organization attached to Ministry of Higher Education and } \\
\text { Research }\end{array}$} \\
\hline $\begin{array}{l}\text { Relationship to } \\
\text { government }\end{array}$ & \multicolumn{4}{|c|}{ A government agency } \\
\hline Funding sources & \multicolumn{4}{|c|}{ Government, connectivity by Ministry of Telecommunications and ICT } \\
\hline $\begin{array}{l}\text { Network backbone } \\
\text { capacity }\end{array}$ & \multicolumn{4}{|c|}{$\begin{array}{l}\text { Based on the national backbone of TELMA with fiber connections to } \\
\text { member institutions paid for by Government. }\end{array}$} \\
\hline $\begin{array}{l}\text { International REN } \\
\text { connectivity }\end{array}$ & \multicolumn{4}{|c|}{ Awaiting AfricaConnect2 } \\
\hline Services & \multicolumn{4}{|c|}{$\begin{array}{l}\text { e-mail (edu.mg), } 4 \text { site videoconference, monitoring, content } \\
\text { management, Moodle. Other services in production: Madagascar } \\
\text { Digital Library (MDL) }\end{array}$} \\
\hline Middleware services & \multicolumn{4}{|c|}{ LDAP authentication } \\
\hline Comments & \multicolumn{4}{|c|}{ Aware of the potential for a range of services to be offered. } \\
\hline Membership & \multicolumn{4}{|c|}{ http://www.irenala.edu.mg/homepage/les-membres } \\
\hline Type of Institution & $\begin{array}{l}\text { Allowed to serve } \\
\text { this category of } \\
\text { institution? }\end{array}$ & $\begin{array}{l}\text { Number of } \\
\text { institutions } \\
\text { connected }\end{array}$ & $\begin{array}{c}\text { Range of } \\
\text { bandwidth } \\
\text { provided }\end{array}$ & $\begin{array}{c}\text { Market } \\
\text { Share (\%) }\end{array}$ \\
\hline Universities & Yes & 6 & - & - \\
\hline $\begin{array}{l}\text { Teacher training } \\
\text { colleges }\end{array}$ & Yes & & - & - \\
\hline $\begin{array}{l}\text { Colleges of further } \\
\text { education }\end{array}$ & Yes & 5 & - & - \\
\hline Research institutes & Yes & 7 & - & - \\
\hline Secondary schools & - & - & - & - \\
\hline Primary schools & - & - & - & - \\
\hline
\end{tabular}




\begin{tabular}{|l|l|l|l|l|}
\hline $\begin{array}{l}\text { Libraries, museums, } \\
\text { cultural institutions }\end{array}$ & Yes & 1 & - & - \\
\hline $\begin{array}{l}\text { Hospitals (other than } \\
\text { university hospitals) }\end{array}$ & - & - & - & - \\
\hline $\begin{array}{l}\text { Government } \\
\text { departments }\end{array}$ & Yes & 2 & - & - \\
\hline $\begin{array}{l}\text { For-profit } \\
\text { organizations }\end{array}$ & - & - & - & - \\
\hline $\begin{array}{l}\text { International } \\
\text { organizations }\end{array}$ & - & - & - & - \\
\hline
\end{tabular}

\begin{tabular}{|c|c|c|c|c|}
\hline NREN & \multicolumn{4}{|c|}{ MAREN - www.maren.ac.mw } \\
\hline Operational status & \multicolumn{4}{|c|}{ Planning - Level 2.5} \\
\hline Date established & \multicolumn{4}{|c|}{2005} \\
\hline Address & \multicolumn{4}{|c|}{ University of Malawi P.O. Box 278, Zomba, Malawi } \\
\hline Contact & \multicolumn{4}{|c|}{ CEO: Benedicto Okomaatani Malunga } \\
\hline Governance & \multicolumn{4}{|c|}{ Not-for-profit independent organization } \\
\hline $\begin{array}{l}\text { Relationship to } \\
\text { government }\end{array}$ & \multicolumn{4}{|c|}{ Recognized by Ministry of Education, Science and Technology } \\
\hline Funding sources & \multicolumn{4}{|c|}{$\begin{array}{l}\text { Startup funding by FRENIA (Fostering Research and Education } \\
\text { Networking In Africa). }\end{array}$} \\
\hline $\begin{array}{l}\text { Network backbone } \\
\text { capacity }\end{array}$ & \multicolumn{4}{|c|}{ Some connectivity to three universities } \\
\hline $\begin{array}{l}\text { International REN } \\
\text { connectivity }\end{array}$ & \multicolumn{4}{|l|}{-} \\
\hline Services & \multicolumn{4}{|l|}{-} \\
\hline Middleware services & \multicolumn{4}{|c|}{ eduroam implemented in four institutions } \\
\hline Comments & \multicolumn{4}{|c|}{-} \\
\hline Membership & \multicolumn{4}{|l|}{-} \\
\hline Type of Institution & $\begin{array}{l}\text { Allowed to serve } \\
\text { this category of } \\
\text { institution? }\end{array}$ & $\begin{array}{l}\text { Number of } \\
\text { institutions } \\
\text { connected }\end{array}$ & $\begin{array}{c}\text { Range of } \\
\text { bandwidth } \\
\text { provided }\end{array}$ & $\begin{array}{c}\text { Market } \\
\text { Share (\%) }\end{array}$ \\
\hline Universities & Yes & $\begin{array}{l}3 \text { on } 9 \\
\text { sites }\end{array}$ & - & - \\
\hline $\begin{array}{l}\text { Teacher training } \\
\text { colleges }\end{array}$ & - & - & - & - \\
\hline $\begin{array}{l}\text { Colleges of further } \\
\text { education }\end{array}$ & - & - & - & - \\
\hline Research institutes & - & - & - & - \\
\hline Secondary schools & - & - & - & - \\
\hline Primary schools & - & - & - & - \\
\hline $\begin{array}{l}\text { Libraries, museums, } \\
\text { cultural institutions }\end{array}$ & Yes & - & - & - \\
\hline $\begin{array}{l}\text { Hospitals (other than } \\
\text { university hospitals) }\end{array}$ & - & - & - & - \\
\hline $\begin{array}{l}\text { Government } \\
\text { departments }\end{array}$ & - & - & - & - \\
\hline
\end{tabular}




\begin{tabular}{|l|c|l|l|l|}
\hline $\begin{array}{l}\text { For-profit } \\
\text { organizations }\end{array}$ & - & - & - & - \\
\hline $\begin{array}{l}\text { International } \\
\text { organizations }\end{array}$ & - & - & - & - \\
\hline
\end{tabular}

Mauritius
\begin{tabular}{|l|l|}
\hline NREN & None \\
\hline Operational status & Planning. Level 2 development \\
\hline Date established & - \\
\hline Address & - \\
\hline Contact & Roshan Halkhoree r.halkhoree@uom.ac.mu \\
\hline
\end{tabular}

\begin{tabular}{|c|c|c|c|c|}
\hline \multicolumn{5}{|l|}{ Mozambique } \\
\hline NREN & \multicolumn{4}{|c|}{ MoRENet - www.morenet.ac.mz } \\
\hline Operational status & \multicolumn{4}{|c|}{ Operational - Level 4.5 development } \\
\hline Date established & \multicolumn{4}{|c|}{2010} \\
\hline Address & \multirow{2}{*}{\multicolumn{4}{|c|}{$\begin{array}{l}\text { Parque da Ciencia e Tecnologia da Maluana, Estrada N1, Km60 } \\
\text { CEO: Ludmila Maguni, Ludmila.Maguni@mctestp.gov.mz, Mob:+258 } \\
843989001\end{array}$}} \\
\hline Contact & & & & \\
\hline Governance & \multicolumn{4}{|c|}{ Becoming separate legal entity in 2015} \\
\hline $\begin{array}{l}\text { Relationship to } \\
\text { government }\end{array}$ & \multicolumn{4}{|c|}{$\begin{array}{l}\text { Part of Ministry of Science and Technology, and planned and financed } \\
\text { through the World Bank Mozambique e-Government and } \\
\text { Communication Infrastructure Project (MEGCIP) project }\end{array}$} \\
\hline Funding sources & \multicolumn{4}{|c|}{ Government, World Bank (MEGCIP) } \\
\hline Operating budget & \multicolumn{4}{|c|}{2015 - US $\$ 500,000$} \\
\hline Staff FTEs & \multicolumn{4}{|l|}{5} \\
\hline $\begin{array}{l}\text { Network backbone } \\
\text { capacity }\end{array}$ & \multicolumn{4}{|l|}{-} \\
\hline $\begin{array}{l}\text { International REN } \\
\text { connectivity }\end{array}$ & \multicolumn{4}{|c|}{$\begin{array}{l}1 \times \text { STM-1 to UbuntuNet Alliance } \\
1 \times \text { STM-1 to London UbuntuNet Alliance router }\end{array}$} \\
\hline Services & \multicolumn{4}{|c|}{ Internet, experimenting with videoconferencing. } \\
\hline Middleware services & \multicolumn{4}{|c|}{ - } \\
\hline Comments & \multicolumn{4}{|c|}{$\begin{array}{l}\text { All services currently offered free. It will pose problems when charges } \\
\text { are applied. }\end{array}$} \\
\hline Membership & \multicolumn{4}{|c|}{ Will be $100 \%$ of universities by August 2015} \\
\hline Type of Institution & $\begin{array}{l}\text { Allowed to serve } \\
\text { this category of } \\
\text { institution? }\end{array}$ & $\begin{array}{l}\text { Number of } \\
\text { institutions } \\
\text { connected }\end{array}$ & $\begin{array}{c}\text { Range of } \\
\text { bandwidth } \\
\text { provided }\end{array}$ & $\begin{array}{c}\text { Market } \\
\text { Share (\%) }\end{array}$ \\
\hline Universities & Yes & 11 & $\begin{array}{l}\text { 34-155 } \\
\text { Mbps }\end{array}$ & $\begin{array}{l}100 \\
\text { by } \\
\text { Augu } \\
\text { st } \\
2015\end{array}$ \\
\hline $\begin{array}{l}\text { Teacher training } \\
\text { colleges }\end{array}$ & Yes & 0 & - & - \\
\hline $\begin{array}{l}\text { Colleges of further } \\
\text { education }\end{array}$ & Planned & 0 & - & - \\
\hline Research institutes & Yes & 5 & 34 & \\
\hline Secondary schools & - & - & - & - \\
\hline Primary schools & - & - & - & - \\
\hline
\end{tabular}




\begin{tabular}{|l|l|l|l|l|}
\hline $\begin{array}{l}\text { Libraries, museums, } \\
\text { cultural institutions }\end{array}$ & Yes & 1 & 34 & \\
\hline $\begin{array}{l}\text { Hospitals (other than } \\
\text { university hospitals) }\end{array}$ & - & - & - & - \\
\hline $\begin{array}{l}\text { Government } \\
\text { departments }\end{array}$ & Yes & - & - & - \\
\hline $\begin{array}{l}\text { For-profit } \\
\text { organizations }\end{array}$ & - & - & - & - \\
\hline $\begin{array}{l}\text { International } \\
\text { organizations }\end{array}$ & - & - & - & - \\
\hline
\end{tabular}

\begin{tabular}{|c|c|c|c|c|}
\hline \multicolumn{5}{|l|}{ Namibia } \\
\hline NREN & \multicolumn{4}{|c|}{ Xnet } \\
\hline Operational status & \multicolumn{4}{|c|}{ Operational. Level 4 development } \\
\hline Date established & \multicolumn{4}{|c|}{2004 as provider to schools and 2007 as NREN } \\
\hline Address & \multicolumn{4}{|c|}{-} \\
\hline Contact & \multicolumn{4}{|c|}{ CEO: Wilfred Kuria, CTO: Marco Maartens. +264 612933372} \\
\hline Governance & \multicolumn{4}{|c|}{ Xnet Development Trust } \\
\hline $\begin{array}{l}\text { Relationship to } \\
\text { Government }\end{array}$ & \multicolumn{4}{|c|}{-} \\
\hline Funding sources & \multicolumn{4}{|l|}{ - } \\
\hline Operating Budget & \multicolumn{4}{|l|}{ - } \\
\hline Staffing (FTEs) & \multicolumn{4}{|l|}{ - } \\
\hline $\begin{array}{l}\text { Network backbone } \\
\text { capacity }\end{array}$ & \multicolumn{4}{|l|}{-} \\
\hline $\begin{array}{l}\text { International REN } \\
\text { connectivity }\end{array}$ & \multicolumn{4}{|l|}{-} \\
\hline Services & \multicolumn{4}{|c|}{ e-learning, email provisioning, website hosting, } \\
\hline Middleware services & \multicolumn{4}{|c|}{ Spam filtering } \\
\hline Comments & \multicolumn{4}{|l|}{-} \\
\hline Membership & \multicolumn{4}{|l|}{ - } \\
\hline Type of Institution & $\begin{array}{l}\text { Allowed to serve } \\
\text { this category of } \\
\text { institution? }\end{array}$ & $\begin{array}{l}\text { Number of } \\
\text { institutions } \\
\text { connected }\end{array}$ & $\begin{array}{c}\text { Range of } \\
\text { bandwidth } \\
\text { provided }\end{array}$ & $\begin{array}{c}\text { Market } \\
\text { Share (\%) }\end{array}$ \\
\hline Universities & Yes & - & - & - \\
\hline $\begin{array}{l}\text { Teacher training } \\
\text { colleges }\end{array}$ & Yes & - & - & - \\
\hline $\begin{array}{l}\text { Colleges of further } \\
\text { education }\end{array}$ & Yes & - & - & - \\
\hline Research institutes & Yes & - & - & - \\
\hline Secondary schools & Yes & - & - & - \\
\hline Primary schools & Yes & - & - & - \\
\hline $\begin{array}{l}\text { Libraries, museums, } \\
\text { cultural institutions }\end{array}$ & - & - & - & - \\
\hline $\begin{array}{l}\text { Hospitals (other than } \\
\text { university hospitals) }\end{array}$ & - & - & - & - \\
\hline $\begin{array}{l}\text { Government } \\
\text { departments }\end{array}$ & Yes & 1 & - & - \\
\hline $\begin{array}{l}\text { For-profit } \\
\text { organizations }\end{array}$ & - & - & - & - \\
\hline $\begin{array}{l}\text { International } \\
\text { organizations }\end{array}$ & - & - & - & - \\
\hline
\end{tabular}




\section{Rwanda}

\begin{tabular}{|c|c|c|c|c|}
\hline NREN & \multicolumn{4}{|l|}{ RwEdNet } \\
\hline Operational status & \multicolumn{4}{|c|}{ Established but network not operational. Level 2.5 development } \\
\hline Date established & \multicolumn{4}{|c|}{-} \\
\hline Address & \multicolumn{4}{|c|}{-} \\
\hline Contact & \multicolumn{4}{|c|}{$\begin{array}{l}\text { Mr. Kayumba Theogene on tkayumba@mineduc.gov.rw + } 240 \\
785150072\end{array}$} \\
\hline Governance & \multicolumn{4}{|c|}{-} \\
\hline $\begin{array}{l}\text { Relationship to } \\
\text { government }\end{array}$ & \multicolumn{4}{|l|}{-} \\
\hline Funding sources & \multicolumn{4}{|c|}{$\begin{array}{l}\text { Rwanda Utilities Regulatory Agency (RURA) UAF subsidized } \\
\text { bandwidth }\end{array}$} \\
\hline Operating budget & \multicolumn{4}{|c|}{-} \\
\hline Staffing (FTEs) & \multicolumn{4}{|l|}{ - } \\
\hline $\begin{array}{l}\text { Network backbone } \\
\text { capacity }\end{array}$ & \multicolumn{4}{|l|}{-} \\
\hline $\begin{array}{l}\text { International REN } \\
\text { connectivity }\end{array}$ & \multicolumn{4}{|l|}{-} \\
\hline Services & \multicolumn{4}{|l|}{ - } \\
\hline Middleware services & \multicolumn{4}{|l|}{ - } \\
\hline Comments & \multirow{2}{*}{\multicolumn{4}{|c|}{$\begin{array}{c}- \\
\end{array}$}} \\
\hline Membership & & & & \\
\hline Type of Institution & $\begin{array}{l}\text { Allowed to serve } \\
\text { this category of } \\
\text { institution? }\end{array}$ & $\begin{array}{l}\text { Number of } \\
\text { institutions } \\
\text { connected }\end{array}$ & $\begin{array}{c}\text { Range of } \\
\text { bandwidth } \\
\text { provided }\end{array}$ & $\begin{array}{l}\text { Market } \\
\text { Share (\%) }\end{array}$ \\
\hline Universities & - & - & - & - \\
\hline $\begin{array}{l}\text { Teacher training } \\
\text { colleges }\end{array}$ & - & - & - & - \\
\hline $\begin{array}{l}\text { Colleges of further } \\
\text { education }\end{array}$ & - & - & - & - \\
\hline Research institutes & - & - & - & - \\
\hline Secondary schools & - & - & - & - \\
\hline Primary schools & - & - & - & - \\
\hline $\begin{array}{l}\text { Libraries, museums, } \\
\text { cultural institutions }\end{array}$ & - & - & - & - \\
\hline $\begin{array}{l}\text { Hospitals (other than } \\
\text { university hospitals) }\end{array}$ & - & - & - & - \\
\hline $\begin{array}{l}\text { Government } \\
\text { departments }\end{array}$ & - & - & - & - \\
\hline $\begin{array}{l}\text { For-profit } \\
\text { organizations }\end{array}$ & - & - & - & - \\
\hline $\begin{array}{l}\text { International } \\
\text { organizations }\end{array}$ & - & - & - & - \\
\hline
\end{tabular}

\section{Seychelles}

\begin{tabular}{|l|l|}
\hline NREN & None \\
\hline Operational status & Non-operational. Level 1 development \\
\hline Date established & - \\
\hline Address & - \\
\hline Contact & - \\
\hline Comments & - \\
\hline
\end{tabular}




\section{Somalia}

\begin{tabular}{|c|c|c|c|c|}
\hline NREN & \multicolumn{4}{|c|}{ SomaliREN } \\
\hline Operational status & \multicolumn{4}{|c|}{ Non-operational, Level 3 development } \\
\hline Date established & \multicolumn{4}{|c|}{2006} \\
\hline Address & \multicolumn{4}{|c|}{$\begin{array}{l}\text { SomaliREN Admin. Office, } \\
\text { SIMAD University Main Campus, Wadada Warshadaha, } \\
\text { Mogadishu, Somalia }\end{array}$} \\
\hline Contact & \multicolumn{4}{|c|}{$\begin{array}{l}\text { CEO: Dahir Hassan Arab, CTO: Abdullahi Bihi Hussein; } \\
\text { abdillahibehi@somaliren.org; +254204440633 }\end{array}$} \\
\hline Governance & \multicolumn{4}{|c|}{ Non-profit NGO owned by the universities } \\
\hline $\begin{array}{l}\text { Relationship to } \\
\text { government }\end{array}$ & \multicolumn{4}{|c|}{ Independent } \\
\hline Funding sources & \multicolumn{4}{|c|}{$\begin{array}{l}\text { World Bank (for counterpart funding of AfricaConnect participation and } \\
\text { for some internal connectivity of universities) }\end{array}$} \\
\hline Operating budget & \multicolumn{4}{|c|}{-} \\
\hline Staffing (FTEs) & \multicolumn{4}{|l|}{ - } \\
\hline $\begin{array}{l}\text { Network backbone } \\
\text { capacity }\end{array}$ & \multicolumn{4}{|c|}{ ( } \\
\hline $\begin{array}{l}\text { International REN } \\
\text { connectivity }\end{array}$ & \multicolumn{4}{|c|}{ Awaiting AfricaConnect2 with funds from ICT World Bank project } \\
\hline Services & \multicolumn{4}{|c|}{$\begin{array}{l}\text { Envisaged: video-conferencing facility, central storage and file } \\
\text { repository, shared e-Learning platform in the very near future. }\end{array}$} \\
\hline Middleware services & \multicolumn{4}{|c|}{-} \\
\hline Comments & \multicolumn{4}{|l|}{ - } \\
\hline Membership & \multicolumn{4}{|l|}{-} \\
\hline Type of Institution & $\begin{array}{l}\text { Allowed to serve } \\
\text { this category of } \\
\text { institution? }\end{array}$ & $\begin{array}{l}\text { Number of } \\
\text { institutions } \\
\text { connected }\end{array}$ & $\begin{array}{c}\text { Range of } \\
\text { bandwidth } \\
\text { provided }\end{array}$ & $\begin{array}{c}\text { Market } \\
\text { Share (\%) }\end{array}$ \\
\hline Universities & - & - & - & - \\
\hline $\begin{array}{l}\text { Teacher training } \\
\text { colleges }\end{array}$ & - & - & - & - \\
\hline $\begin{array}{l}\text { Colleges of further } \\
\text { education }\end{array}$ & - & - & - & - \\
\hline Research institutes & - & - & - & - \\
\hline Secondary schools & - & - & - & - \\
\hline Primary schools & - & - & - & - \\
\hline $\begin{array}{l}\text { Libraries, museums, } \\
\text { cultural institutions }\end{array}$ & - & - & - & - \\
\hline $\begin{array}{l}\text { Hospitals (other than } \\
\text { university hospitals) }\end{array}$ & - & - & - & - \\
\hline $\begin{array}{l}\text { Government } \\
\text { departments }\end{array}$ & - & - & - & - \\
\hline $\begin{array}{l}\text { For-profit } \\
\text { organizations }\end{array}$ & - & - & - & - \\
\hline $\begin{array}{l}\text { International } \\
\text { organizations }\end{array}$ & - & - & - & - \\
\hline
\end{tabular}

\section{South Africa}

\begin{tabular}{|l|l|}
\hline NREN & TENET - www.tenet.ac.za . Manages SANReN network \\
\hline Operational status & Operational with REN connectivity Level 6 development \\
\hline Date established & August 2000 \\
\hline Address & P O Box 18094, Wynberg, 7824, South Africa \\
\hline
\end{tabular}




\begin{tabular}{|c|c|c|c|c|}
\hline Contact & \multicolumn{4}{|c|}{ Tel: +27 217637140} \\
\hline Governance & \multicolumn{4}{|c|}{ Non-Profit Company, managed by Board of 13} \\
\hline $\begin{array}{l}\text { Relationship to } \\
\text { government }\end{array}$ & \multicolumn{4}{|c|}{$\begin{array}{l}\text { Dept. Science and Technology charged the Meraka Institute to build } \\
\text { the SANReN infrastructure, which TENET manages. }\end{array}$} \\
\hline Funding sources & \multicolumn{4}{|c|}{-} \\
\hline Operating budget & \multicolumn{4}{|l|}{ - } \\
\hline Staffing (FTEs) & \multicolumn{4}{|l|}{15} \\
\hline $\begin{array}{l}\text { Network backbone } \\
\text { capacity }\end{array}$ & \multicolumn{4}{|c|}{$\begin{array}{l}\text { The SANReN } 10 \text { Gbps backbone, SANReN fiber rings in } \\
\text { Johannesburg, Pretoria, Cape Town and Durban, the GEN3 MPLS } \\
\text { network and Metro-E circuits provided by Neotel, IP Connect bandwidth } \\
\text { into the ADSL cloud, and various optical fibre and wireless access } \\
\text { circuits }\end{array}$} \\
\hline $\begin{array}{l}\text { International REN } \\
\text { connectivity }\end{array}$ & \multicolumn{4}{|c|}{$2 \times 10$ Gbps links to London carrying UbuntuNet traffic } \\
\hline Services & \multicolumn{4}{|c|}{ http://www.tenet.ac.za/about/about-tenet-1 } \\
\hline Middleware services & \multicolumn{4}{|c|}{-} \\
\hline Comments & \multicolumn{4}{|c|}{-} \\
\hline Membership & \multicolumn{4}{|c|}{ All public universities and science councils eligible. 55 members. } \\
\hline Type of Institution & $\begin{array}{l}\text { Allowed to serve } \\
\text { this category of } \\
\text { institution? }\end{array}$ & $\begin{array}{l}\text { Number of } \\
\text { institutions } \\
\text { connected }\end{array}$ & $\begin{array}{c}\text { Range of } \\
\text { bandwidth } \\
\text { provided }\end{array}$ & $\begin{array}{c}\text { Market } \\
\text { Share (\%) }\end{array}$ \\
\hline Universities & - & - & - & - \\
\hline $\begin{array}{l}\text { Teacher training } \\
\text { colleges }\end{array}$ & - & - & - & - \\
\hline $\begin{array}{l}\text { Colleges of further } \\
\text { education }\end{array}$ & - & - & - & - \\
\hline Research institutes & - & - & - & - \\
\hline Secondary schools & - & - & - & - \\
\hline Primary schools & - & - & - & - \\
\hline $\begin{array}{l}\text { Libraries, museums, } \\
\text { cultural institutions }\end{array}$ & - & - & - & - \\
\hline $\begin{array}{l}\text { Hospitals (other than } \\
\text { university hospitals) }\end{array}$ & - & - & - & - \\
\hline $\begin{array}{l}\text { Government } \\
\text { departments }\end{array}$ & - & - & - & - \\
\hline $\begin{array}{l}\text { For-profit } \\
\text { organizations }\end{array}$ & - & - & - & - \\
\hline $\begin{array}{l}\text { International } \\
\text { organizations }\end{array}$ & - & - & - & - \\
\hline
\end{tabular}

\section{South Sudan}

\begin{tabular}{|l|l|}
\hline NREN & None \\
\hline Operational status & Not operational. Level 2 development \\
\hline Date established & - \\
\hline Address & - \\
\hline Contact & - \\
\hline Comments & - \\
\hline
\end{tabular}

\section{Sudan}

\begin{tabular}{|l|l|}
\hline NREN & SudREN - www.sudren.edu.sd \\
\hline Operational status & Operational. Level 4 development \\
\hline Date established & Originally SUIN/SUVL in 2004, changed to SudREN in 2009 \\
\hline
\end{tabular}




\begin{tabular}{|c|c|c|c|c|}
\hline Address & \multicolumn{4}{|c|}{$\begin{array}{l}\text { Information Technology and Network Administration (ITNA), Algamaa } \\
\text { Street. } \\
\text { P.O. BOX } 321 / 22,11115 \text {, University of Khartoum, Khartoum, Sudan }\end{array}$} \\
\hline Contact & \multicolumn{4}{|c|}{$\begin{array}{l}\text { Chairman: Iman Abuel Maaly: ceo@suin.edu.sd. +249 } 155661600 \text { Ext.: } \\
600 \\
\text { CTO: Yassir Hassan Elamin Hassan yassir@suin.edu.sd; +249 } \\
\text { 12378884 } \\
\text { Other: info@suin.edu.sd }\end{array}$} \\
\hline Governance & \multicolumn{4}{|c|}{ NGO as unit of Association of Sudanese Universities } \\
\hline $\begin{array}{l}\text { Relationship to } \\
\text { government }\end{array}$ & \multicolumn{4}{|c|}{ No formal relationship } \\
\hline Funding sources & \multicolumn{4}{|c|}{$60 \%$ members, 35\% UAFs, $5 \%$ AAU for capacity building } \\
\hline Operating budget & \multicolumn{4}{|c|}{ US $\$ 1,827,242$ for 2015} \\
\hline Staffing (FTEs) & \multicolumn{4}{|c|}{-} \\
\hline $\begin{array}{l}\text { Network backbone } \\
\text { capacity }\end{array}$ & \multicolumn{4}{|l|}{1 Gbps backbone } \\
\hline $\begin{array}{l}\text { International REN } \\
\text { connectivity }\end{array}$ & \multicolumn{4}{|c|}{$\begin{array}{l}\text { Awaiting solution to embargo to pay AfricaConnect fee. Commodity } \\
\text { Internet ( } 310 \mathrm{Mbps} \text { from Sudatel, } 155 \text { from Canar) }\end{array}$} \\
\hline Services & \multicolumn{4}{|c|}{$\begin{array}{l}\text { Video uploads, live streaming, e-libraries/journals, hosting, centralized } \\
\text { videoconferencing, training }\end{array}$} \\
\hline Middleware services & \multicolumn{4}{|c|}{-} \\
\hline Comments & \multicolumn{4}{|l|}{-} \\
\hline Membership & \multicolumn{4}{|l|}{-} \\
\hline Type of Institution & $\begin{array}{l}\text { Allowed to serve } \\
\text { this category of } \\
\text { institution? }\end{array}$ & $\begin{array}{l}\text { Number of } \\
\text { institutions } \\
\text { connected }\end{array}$ & $\begin{array}{c}\text { Range of } \\
\text { bandwidth } \\
\text { provided }\end{array}$ & $\begin{array}{c}\text { Market } \\
\text { Share (\%) }\end{array}$ \\
\hline Universities & Yes & 35 & $\begin{array}{l}2-50 \\
\text { Mbps }\end{array}$ & 100 \\
\hline $\begin{array}{l}\text { Teacher training } \\
\text { colleges }\end{array}$ & Yes & 2 & - & - \\
\hline $\begin{array}{l}\text { Colleges of further } \\
\text { education }\end{array}$ & Yes & 37 & $\begin{array}{l}1-2 \\
\text { Mbps }\end{array}$ & \\
\hline Research institutes & Yes & 8 & - & - \\
\hline Secondary schools & No & - & - & - \\
\hline Primary schools & No & - & - & - \\
\hline $\begin{array}{l}\text { Libraries, museums, } \\
\text { cultural institutions }\end{array}$ & Yes & 2 & - & - \\
\hline $\begin{array}{l}\text { Hospitals (other than } \\
\text { university hospitals) }\end{array}$ & No & - & - & - \\
\hline $\begin{array}{l}\text { Government } \\
\text { departments }\end{array}$ & No & - & - & - \\
\hline $\begin{array}{l}\text { For-profit } \\
\text { organizations }\end{array}$ & No & - & - & - \\
\hline $\begin{array}{l}\text { International } \\
\text { organizations }\end{array}$ & No & - & - & - \\
\hline
\end{tabular}

\section{Swaziland}

\begin{tabular}{|l|l|}
\hline NREN & None \\
\hline Operational status & No longer serviced by TENET, possibly due to inability to pay \\
\hline Date established & - \\
\hline Address & - \\
\hline Contact & Professor Cisco Magagula ciscomag@uniswacc.uniswa.sz \\
\hline
\end{tabular}




\section{Tanzania}

\begin{tabular}{|c|c|c|c|c|}
\hline NREN & \multicolumn{4}{|c|}{ TERNET - www.ternet.or.tz } \\
\hline Operational status & \multicolumn{4}{|c|}{ Operational. Level 4.5 development } \\
\hline Date established & \multicolumn{4}{|c|}{ Early effort in 2002. Formally March 2007} \\
\hline Address & \multicolumn{4}{|c|}{$\begin{array}{l}\text { P.O.Box 95062, COSTECH Building 1st Floor, Kijitonyama (Sayansi), } \\
\text { All Hassani Mwinyi Road, Dar es Salaam. }\end{array}$} \\
\hline Contact & \multicolumn{4}{|c|}{$\begin{array}{l}\text { Executive Secretary: Dr. Amos Nungu, info@ternet.or.tz, +255- } \\
787716778\end{array}$} \\
\hline Governance & \multicolumn{4}{|c|}{ Trust, Independent organization } \\
\hline $\begin{array}{l}\text { Relationship to } \\
\text { government }\end{array}$ & \multicolumn{4}{|c|}{$\begin{array}{l}\text { Independent but connectivity to NOC funded by government. NOC } \\
\text { hosted at Commission of Science and Technology (COSTECH) }\end{array}$} \\
\hline Funding sources & \multicolumn{4}{|c|}{ Government in-kind funding (supports NOC), Ministry of Science } \\
\hline Operating budget & \multicolumn{4}{|c|}{-} \\
\hline Staffing (FTEs) & \multicolumn{4}{|l|}{ - } \\
\hline $\begin{array}{l}\text { Network backbone } \\
\text { capacity }\end{array}$ & \multicolumn{4}{|l|}{-} \\
\hline $\begin{array}{l}\text { International REN } \\
\text { connectivity }\end{array}$ & \multicolumn{4}{|c|}{ STM-1 (155Mbps) on SEACOM to London UbuntuNet Alliance router } \\
\hline Services & \multicolumn{4}{|l|}{ Internet service } \\
\hline Middleware services & \multicolumn{4}{|c|}{ Identity provider (SAML) based on Shibboleth by Internet2 } \\
\hline Comments & \multicolumn{4}{|c|}{$\begin{array}{l}\text { University of Dar es Salaam has its own STM-1 international } \\
\text { connectivity from Seacom (contact: Charles N. Tarimo) }\end{array}$} \\
\hline Membership & \multicolumn{4}{|c|}{-} \\
\hline Type of Institution & $\begin{array}{l}\text { Allowed to serve } \\
\text { this category of } \\
\text { institution? }\end{array}$ & $\begin{array}{l}\text { Number of } \\
\text { institutions } \\
\text { connected }\end{array}$ & $\begin{array}{c}\text { Range of } \\
\text { bandwidth } \\
\text { provided }\end{array}$ & $\begin{array}{c}\text { Market } \\
\text { Share (\%) }\end{array}$ \\
\hline Universities & Yes & 7 & $\begin{array}{l}- \\
15 \mathrm{Mbps} \\
\end{array}$ & - \\
\hline $\begin{array}{l}\text { Teacher training } \\
\text { colleges }\end{array}$ & Yes & 0 & & - \\
\hline $\begin{array}{l}\text { Colleges of further } \\
\text { Education }\end{array}$ & Yes & 4 & $\begin{array}{l}8-15 \\
\text { Mbps }\end{array}$ & - \\
\hline Research institutes & Yes & 4 & $\begin{array}{l}8-15 \\
\text { Mbps }\end{array}$ & - \\
\hline Secondary schools & - & - & - & - \\
\hline Primary schools & - & - & - & - \\
\hline $\begin{array}{l}\text { Libraries, museums, } \\
\text { cultural institutions }\end{array}$ & Yes & 1 & - & - \\
\hline $\begin{array}{l}\text { Hospitals (other than } \\
\text { university hospitals) }\end{array}$ & - & - & - & - \\
\hline $\begin{array}{l}\text { Government } \\
\text { departments }\end{array}$ & Yes & 3 & $\begin{array}{l}8- \\
15 \mathrm{Mbps}\end{array}$ & - \\
\hline $\begin{array}{l}\text { For-profit } \\
\text { organizations }\end{array}$ & - & - & - & - \\
\hline $\begin{array}{l}\text { International } \\
\text { organizations }\end{array}$ & - & - & - & - \\
\hline
\end{tabular}

\section{Uganda}

\begin{tabular}{|l|l|}
\hline NREN & RENU - https://www.renu.ac.ug \\
\hline Operational status & Operational. Level 5 development \\
\hline
\end{tabular}




\begin{tabular}{|c|c|c|c|c|}
\hline Date established & \multicolumn{4}{|c|}{$\begin{array}{l}\text { January 2006, consortium formed. July } 2010 \text { Licensed to operate a } \\
\text { network }\end{array}$} \\
\hline Address & \multicolumn{4}{|c|}{ Makerere University, Kampala } \\
\hline Contact & \multicolumn{4}{|c|}{$\begin{array}{l}\text { Isaac Kasana CEO +256 77790043, ceo@renu.ac.ug, CTO: } \\
\text { cto@renu.ac.ug }\end{array}$} \\
\hline Governance & \multicolumn{4}{|c|}{ Not-for-profit membership organization } \\
\hline $\begin{array}{l}\text { Relationship to } \\
\text { government }\end{array}$ & \multicolumn{4}{|c|}{$\begin{array}{l}\text { Recognized by Ministry of ICT and Ministry of Education and Sports. } \\
\text { UCC and NITA-U represented on Board }\end{array}$} \\
\hline Funding sources & \multicolumn{4}{|c|}{$\begin{array}{l}\text { 85\% from members, Government for AfricaConnect, donations, } \\
\text { US } \$ 600,000 \text { from USAID. }\end{array}$} \\
\hline Operating budget & \multicolumn{4}{|c|}{ US\$1.2 million for 2015} \\
\hline Staffing (FTEs) & \multicolumn{4}{|c|}{4 staff plus some occasional for events } \\
\hline $\begin{array}{l}\text { Network backbone } \\
\text { capacity }\end{array}$ & \multicolumn{4}{|c|}{$\begin{array}{l}1 \text { Gbps backbone, } 870 \text { Mbps Commodity Internet. Google Link project } \\
\text { in Kampala }\end{array}$} \\
\hline $\begin{array}{l}\text { International REN } \\
\text { connectivity }\end{array}$ & \multicolumn{4}{|c|}{ Through UbuntuNet to London/Amsterdam to GÉANT } \\
\hline Services & \multicolumn{4}{|c|}{ MM content repository (4TB), e-learning, Google Cache, } \\
\hline Middleware services & \multicolumn{4}{|c|}{-} \\
\hline Comments & \multicolumn{4}{|l|}{ - } \\
\hline Membership & \multicolumn{4}{|l|}{ - } \\
\hline Type of Institution & $\begin{array}{l}\text { Allowed to serve } \\
\text { this category of } \\
\text { institution? }\end{array}$ & $\begin{array}{l}\text { Number of } \\
\text { institutions } \\
\text { connected }\end{array}$ & $\begin{array}{c}\text { Range of } \\
\text { bandwidth } \\
\text { provided }\end{array}$ & $\begin{array}{c}\text { Market } \\
\text { Share (\%) }\end{array}$ \\
\hline Universities & Yes & 16 & $\begin{array}{l}5-200 \\
\text { Mbps }\end{array}$ & 40 \\
\hline $\begin{array}{l}\text { Teacher training } \\
\text { colleges }\end{array}$ & Yes & $\begin{array}{l}\text { In } \\
\text { universiti } \\
\text { es }\end{array}$ & - & - \\
\hline $\begin{array}{l}\text { Colleges of further } \\
\text { education }\end{array}$ & Yes & - & - & - \\
\hline Research institutes & Yes & 5 & - & 40 \\
\hline Secondary schools & Yes & 0 & - & - \\
\hline Primary schools & Yes & 0 & - & - \\
\hline $\begin{array}{l}\text { Libraries, museums, } \\
\text { cultural institutions }\end{array}$ & Yes & 0 & - & - \\
\hline $\begin{array}{l}\text { Hospitals (other than } \\
\text { university hospitals) }\end{array}$ & No. NITA to handle & - & - & - \\
\hline $\begin{array}{l}\text { Government } \\
\text { departments }\end{array}$ & No. NITA to handle & - & - & - \\
\hline $\begin{array}{l}\text { For-profit } \\
\text { organizations }\end{array}$ & No & - & - & - \\
\hline $\begin{array}{l}\text { International } \\
\text { organizations }\end{array}$ & $\begin{array}{l}\text { If research and } \\
\text { education }\end{array}$ & - & - & - \\
\hline
\end{tabular}

\section{Zambia}

\begin{tabular}{|l|l|}
\hline NREN & ZAMREN - www.zamren.zm \\
\hline Operational status & Operational. Level 5 development \\
\hline Date established & - \\
\hline Address & University of Zambia, Great East Road Campus, Lusaka \\
\hline Contact & CEO: Mr. Bonny Khunga, khungab@zamren.zm +260 211295926 \\
\hline Governance & Separate Not-for-profit organization \\
\hline $\begin{array}{l}\text { Relationship to } \\
\text { government }\end{array}$ & $\begin{array}{l}\text { Indirect. Supported by Ministry of Education and Ministry of } \\
\text { Communications and Transport }\end{array}$ \\
\hline
\end{tabular}




\begin{tabular}{|c|c|c|c|c|}
\hline Funding sources & \multicolumn{4}{|c|}{$\begin{array}{l}\text { Start-up: ZICTA UAFs for last mile, ZESCO Power Company donation } \\
\text { of lambda path on fiber for national backbone, World Bank } \\
\text { (AfricaConnect counterpart payment), Government of the Netherlands } \\
\text { under the Netherlands Initiative for Capacity Development in Higher } \\
\text { Education Program } \\
\text { Current: sale of bandwidth (US\$1.95 million, 2014) }\end{array}$} \\
\hline Operating budget & \multicolumn{4}{|c|}{ US\$2.25 million for 2015} \\
\hline Staffing (FTEs) & \multicolumn{4}{|c|}{11} \\
\hline $\begin{array}{l}\text { Network backbone } \\
\text { capacity }\end{array}$ & \multicolumn{4}{|c|}{ One 1 Gbps Lambda path on ZESCO Power lines } \\
\hline $\begin{array}{l}\text { International REN } \\
\text { connectivity }\end{array}$ & \multicolumn{4}{|c|}{ Connected to UbuntuNet Alliance } \\
\hline Services & \multicolumn{4}{|c|}{$\begin{array}{l}\text { Broadband Connectivity with Internet, Support MOODLE, Off-shore } \\
\text { backup, Mail and Web hosting } \\
\text { Support for Campus Network Installations and management, } \\
\text { Technical Capacity Building } \\
\text { Have Ipv6 address block, but yet to deploy }\end{array}$} \\
\hline Middleware services & \multicolumn{4}{|c|}{$\begin{array}{l}\text { eduroam deployed in } 3 \text { universities, Domain Name System (DNS) } \\
\text { service }\end{array}$} \\
\hline Comments & \multicolumn{4}{|c|}{$\begin{array}{l}\text { Useful case study in how to get UAF and donations of fiber. } 2 \\
\text { universities have XVD videoconferencing } \\
\text { (http://www. universityworldnews.com/article.php?story=201006171910 } \\
47900 \text { ) } \\
\text { Planning } 1 \text { Gbps Metro circuits for Lusaka, Ndola and Kitwe }\end{array}$} \\
\hline \multicolumn{5}{|c|}{ 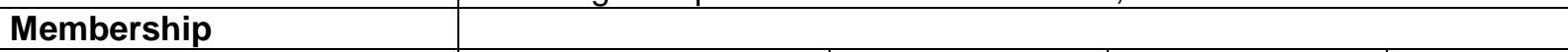 } \\
\hline Type of Institution & $\begin{array}{l}\text { Allowed to serve } \\
\text { this category of } \\
\text { institution? }\end{array}$ & $\begin{array}{l}\text { Number of } \\
\text { institutions } \\
\text { connected }\end{array}$ & $\begin{array}{c}\text { Range of } \\
\text { bandwidth } \\
\text { provided }\end{array}$ & $\begin{array}{c}\text { Market } \\
\text { Share (\%) }\end{array}$ \\
\hline Universities & Yes & 7 & $\begin{array}{l}7.5-230 \\
\text { Mbps }\end{array}$ & 60 \\
\hline $\begin{array}{l}\text { Teacher training } \\
\text { Colleges }\end{array}$ & Yes & 2 & $\begin{array}{l}6-9 \\
\text { Mbps }\end{array}$ & 20 \\
\hline $\begin{array}{l}\text { Colleges of further } \\
\text { education }\end{array}$ & Yes & 18 & $\begin{array}{l}3-15 \\
\text { Mbps }\end{array}$ & 90 \\
\hline $\begin{array}{l}\text { Technical high } \\
\text { schools }\end{array}$ & Yes & 6 & $\begin{array}{l}1.5-7.5 \\
\text { Mbps }\end{array}$ & 60 \\
\hline Trades institutes & - & 2 & $1.5 \mathrm{Mbps}$ & 9 \\
\hline Research institutes & - & 5 & - & 25 \\
\hline Secondary schools & - & - & - & - \\
\hline Primary schools & - & - & - & - \\
\hline $\begin{array}{l}\text { Libraries, museums, } \\
\text { cultural institutions }\end{array}$ & - & - & - & - \\
\hline $\begin{array}{l}\text { Hospitals (other than } \\
\text { university hospitals) }\end{array}$ & - & - & - & - \\
\hline $\begin{array}{l}\text { Government } \\
\text { departments }\end{array}$ & - & - & - & - \\
\hline $\begin{array}{l}\text { For-profit } \\
\text { organizations }\end{array}$ & - & - & - & - \\
\hline $\begin{array}{l}\text { International } \\
\text { organizations }\end{array}$ & - & 1 & $\begin{array}{l}22.5 \\
\text { Mbps }\end{array}$ & - \\
\hline
\end{tabular}




\section{Zimbabwe}

\begin{tabular}{|l|l|}
\hline NREN & ZARNET - www.zarnet.ac.zW \\
\hline Operational status & Non-operational - Level 2 \\
\hline Date established & 1997 \\
\hline Address & 76 Samora Machel Avenue,9th Floor Bank Chambers \\
\hline Contact & Evans Vete: evansv@zarnet.ac.zW \\
\hline Governance & Government entity established by Act of Parliament \\
\hline Comments & $\begin{array}{l}\text { Two NREN organisations existed (ZIMREN and ZARNET) and a } \\
\text { decision was reached in April 2016 to merge them. }\end{array}$ \\
\hline
\end{tabular}




\section{West and Central Africa - WACREN Group}

\section{West and Central African Research and Education Network (WACREN)}

Address: 11 Aviation Road Extension, P O Box 5744, Accra, Ghana

Contacts: $\quad$ CEO: Boubakar Barry

$$
\text { CTO: Omo Oaiya }
$$

info@wacren.net

www.wacren.net

\section{Benin}

\begin{tabular}{|l|l|}
\hline NREN & RerBenin - www.rerbenin.net \\
\hline Operational status & Planning. Level 3 development \\
\hline Date established & Planning workshop July 2013: Report - www.rerbenin.net \\
\hline Address & - \\
\hline Contact & Gilles Kounou: gilles.kounou@gmail.com: info@rerbenin.net \\
\hline Comments & $\begin{array}{l}\text { Some progress on organization, and buy-in from Ministry. Partner in } \\
\text { AfricaConnect2. }\end{array}$ \\
\hline
\end{tabular}

\section{Burkina Faso}

\begin{tabular}{|l|l|}
\hline NREN & FasoREN \\
\hline Operational status & Planning. Level 3 development \\
\hline Date established & - \\
\hline Address & - \\
\hline Contact & - \\
\hline Comments & Possible participation in AfricaConnect2 \\
\hline
\end{tabular}

\section{Cameroon}

\begin{tabular}{|l|l|}
\hline NREN & $\begin{array}{l}\text { RIC (Réseau Interuniversitaire du Cameroun). } \\
\text { www.minesup.gov.cm / www.citi.cm }\end{array}$ \\
\hline Operational status & Planning. Level 3 development \\
\hline Date established & - \\
\hline Address & - \\
\hline Contact & $\begin{array}{l}\text { Mr Yves Emvudu Wono: yemvudu@yahoo.fr } \\
\text { / yemvudu@minesup.gov.cm }\end{array}$ \\
\hline Comments & Partner country in AfricaConnect2 \\
\hline
\end{tabular}

\section{Cape Verde}

\begin{tabular}{|l|l|}
\hline NREN & None \\
\hline Operational status & Planning. Level 1 development \\
\hline Date established & - \\
\hline Address & - \\
\hline Contact & - \\
\hline Comments & - \\
\hline
\end{tabular}




\section{Central African Republic (CAR)}

\begin{tabular}{|l|l|}
\hline NREN & None \\
\hline Operational status & No known action. Level 0 development \\
\hline Date established & - \\
\hline Address & - \\
\hline Contact & - \\
\hline Comments & - \\
\hline
\end{tabular}

\section{Chad}

\begin{tabular}{|l|l|}
\hline NREN & None \\
\hline Operational status & Planning. Level 2 development \\
\hline Date established & - \\
\hline Address & - \\
\hline Contact & - \\
\hline
\end{tabular}

\section{Republic of Congo}

\begin{tabular}{|l|l|}
\hline NREN & None \\
\hline Operational status & No known activity. Level 0 development \\
\hline Date established & - \\
\hline Address & - \\
\hline Contact & - \\
\hline Comments & - \\
\hline
\end{tabular}

\section{Côte d'Ivoire}

\begin{tabular}{|c|c|}
\hline NREN & $\begin{array}{l}\text { RITER (Réseau Ivoirien de Télécommunications pour l'Enseignement } \\
\text { et la Recherche) - www.riter.ci }\end{array}$ \\
\hline Operational status & Operational. Level 4 development \\
\hline Date established & September 2012 \\
\hline Address & $\begin{array}{l}\text { L' Université Félix Houphouët-Boigny à I' IRMA : } 08 \text { BP } 2035 \text { Abidjan } \\
08\end{array}$ \\
\hline Contact & $\begin{array}{l}\text { KONE Tiemoman: tiemoman@wacren.net / tiemoman.kone@univ- } \\
\text { fhb.edu.ci / kone@tiemoman.org; +225 } 07647556\end{array}$ \\
\hline Governance & $\begin{array}{l}\text { Association for governance. Many technical services outsourced until } \\
\text { capacity is built internally. }\end{array}$ \\
\hline $\begin{array}{l}\text { Relationship to } \\
\text { government }\end{array}$ & Government deployed the network \\
\hline Funding sources & $\begin{array}{l}\text { Government: Ministère de l'Enseignement Supérieur et de } \\
\text { la Recherche Scientifique }\end{array}$ \\
\hline Operating budget & - \\
\hline Staffing (FTEs) & - \\
\hline $\begin{array}{l}\text { Network backbone } \\
\text { capacity }\end{array}$ & IP/MPLS connectivity of 100 Mbps commodity Internet to each member \\
\hline $\begin{array}{l}\text { International REN } \\
\text { connectivity }\end{array}$ & Planned for in AfricaConnect2 \\
\hline Services & $\begin{array}{l}\text { Data Center (70 TBs), Videoconferencing in } 8 \text { sites, planning shared } \\
\text { hosting }\end{array}$ \\
\hline Middleware services & - \\
\hline Comments & Partner in AfricaConnect2 \\
\hline Membership & - \\
\hline
\end{tabular}




\begin{tabular}{|l|c|l|l|l|}
\hline Type of Institution & $\begin{array}{l}\text { Allowed to serve } \\
\text { this category of } \\
\text { institution? }\end{array}$ & $\begin{array}{l}\text { Number of } \\
\text { institutions } \\
\text { connected }\end{array}$ & $\begin{array}{c}\text { Range of } \\
\text { bandwidth } \\
\text { provided }\end{array}$ & $\begin{array}{l}\text { Market } \\
\text { Share (\%) }\end{array}$ \\
\hline Universities & Yes & 5 & $\begin{array}{l}100 \\
\text { Mbps }\end{array}$ & - \\
\hline $\begin{array}{l}\text { Teacher training } \\
\text { colleges }\end{array}$ & Yes & - & - & - \\
\hline $\begin{array}{l}\text { Colleges of further } \\
\text { education }\end{array}$ & Yes & 2 & $\begin{array}{l}100 \\
\text { Mbps }\end{array}$ & - \\
\hline Research institutes & Yes & - & - & - \\
\hline Secondary schools & - & - & - & - \\
\hline Primary schools & - & - & - & - \\
\hline $\begin{array}{l}\text { Libraries, museums, } \\
\text { cultural institutions }\end{array}$ & - & - & - & - \\
\hline $\begin{array}{l}\text { Hospitals (other than } \\
\text { university hospitals) }\end{array}$ & - & - & - & - \\
\hline $\begin{array}{l}\text { Government } \\
\text { departments }\end{array}$ & - & - & - & - \\
\hline $\begin{array}{l}\text { For-profit } \\
\text { organizations }\end{array}$ & - & - & - & - \\
\hline $\begin{array}{l}\text { International } \\
\text { organizations }\end{array}$ & - & - & - & - \\
\hline
\end{tabular}

\section{Equatorial Guinea}

\begin{tabular}{|l|l|}
\hline NREN & None \\
\hline Operational status & Unknown - Level 0 development \\
\hline Date established & - \\
\hline Address & - \\
\hline Contact & - \\
\hline
\end{tabular}

\section{Gabon}

\begin{tabular}{|l|l|}
\hline NREN & GabonREN - www.gabonren.ga (under construction) \\
\hline Operational status & Planning - Level 3 development \\
\hline Date established & - \\
\hline Address & $\begin{array}{l}\text { Ministère de l'Enseignement Supérieur et de la Recherche Scientifique } \\
- \text { B.P. 2217 - Libreville }\end{array}$ \\
\hline Contact & $\begin{array}{l}\text { Anicet Claude ANDJOUAT, andjoua@gmail.com_CEO is Prof_Lebib. } \\
+24107810092 . \text { contact@gabonren.ga }\end{array}$ \\
\hline Governance & Planning a PPP \\
\hline $\begin{array}{l}\text { Relationship to } \\
\text { government }\end{array}$ & Part of Government - \\
\hline Funding sources & $\begin{array}{l}\text { Government: Ministère de l'Enseignement Supérieur et de la } \\
\text { Recherche Scientifique }\end{array}$ \\
\hline Operating budget & $\begin{array}{l}\text { All voluntary. PPP Board, President: Prof Lebib, and rectors of three } \\
\text { universities and five Grand Ecoles. Not yet a secretariat. Project team } \\
\text { (voluntary) with director (Anicet), CTO (Private sector) : Gaetan } \\
\text { Bouraga }\end{array}$ \\
\hline $\begin{array}{l}\text { Staffing (FTEs) } \\
\text { No network yet }\end{array}$ \\
\hline $\begin{array}{l}\text { Network backbone } \\
\text { capacity }\end{array}$ & - \\
\hline $\begin{array}{l}\text { International REN } \\
\text { connectivity }\end{array}$ & \\
\hline
\end{tabular}




\begin{tabular}{|c|c|c|c|c|}
\hline Services & \multicolumn{4}{|l|}{ - } \\
\hline Middleware services & \multicolumn{4}{|l|}{ - } \\
\hline Comments & \multicolumn{4}{|c|}{$\begin{array}{l}\text { No network yet. Université de Omar Bongo built campus network } \\
\text { (US } \$ 25,700) \text { with } 20 \text { Mbps from Gabon Telecom at US } \$ 11,865 \text { per } \\
\text { month (US } \$ 593 \text { per Mbps per month). Partner in AfricaConnect2. }\end{array}$} \\
\hline Membership & \multicolumn{4}{|c|}{15 Members } \\
\hline Type of Institution & $\begin{array}{l}\text { Allowed to serve } \\
\text { this category of } \\
\text { institution? }\end{array}$ & $\begin{array}{l}\text { Number of } \\
\text { institutions }\end{array}$ & $\begin{array}{l}\text { Range of } \\
\text { bandwidth } \\
\text { provided }\end{array}$ & $\begin{array}{c}\text { Market } \\
\text { Share (\%) }\end{array}$ \\
\hline Universities & Yes & 3 & - & - \\
\hline $\begin{array}{l}\text { Teacher training } \\
\text { colleges }\end{array}$ & Yes & 2 & - & - \\
\hline $\begin{array}{l}\text { Colleges of further } \\
\text { education }\end{array}$ & - & 5 & - & - \\
\hline Research institutes & - & - & - & - \\
\hline Secondary schools & - & - & - & - \\
\hline Primary schools & - & - & - & - \\
\hline $\begin{array}{l}\text { Libraries, museums, } \\
\text { cultural institutions }\end{array}$ & - & - & - & - \\
\hline $\begin{array}{l}\text { Hospitals (other than } \\
\text { university hospitals) }\end{array}$ & Scheitzer Centre & & - & - \\
\hline $\begin{array}{l}\text { Government } \\
\text { departments }\end{array}$ & Yes & 4 & - & - \\
\hline $\begin{array}{l}\text { For-profit } \\
\text { organizations }\end{array}$ & - & - & - & - \\
\hline $\begin{array}{l}\text { International } \\
\text { organizations }\end{array}$ & Yes & - & - & - \\
\hline
\end{tabular}

\section{The Gambia}

\begin{tabular}{|l|l|}
\hline NREN & None \\
\hline Operational status & Planning. Level 1 development \\
\hline Date established & - \\
\hline Address & - \\
\hline Contact & - \\
\hline Comments & - \\
\hline
\end{tabular}

\section{Ghana}

\begin{tabular}{|l|l|}
\hline NREN & $\begin{array}{l}\text { GARNET (Ghanaian Academic and Research Network) } \\
\text { http://garnet.edu.gh }\end{array}$ \\
\hline Operational status & Planning - Level 3.5 development \\
\hline Date established & Planned since 1995, established 11/2006. Incorporated 8/2010 \\
\hline Address & $\begin{array}{l}\text { GARNET, c/o, the Offices of VCG, P.O. Box LG25 } \\
\text { Legon, Accra, Ghana }\end{array}$ \\
\hline Contact & $\begin{array}{l}\text { Dr Mumuni Dakubu: mdmdakubu@gmail.com / mdakubu@ug.edu.gh; } \\
+233244 \text { 296 001 } \\
\text { Benjamin Eshun: beshun@garnet.edu.gh }\end{array}$ \\
\hline Governance & Non-profit company \\
\hline $\begin{array}{l}\text { Relationship to } \\
\text { government }\end{array}$ & Indirect (some board members are from public universities) \\
\hline Funding sources & Awaiting funding from government \\
\hline Operating budget & - \\
\hline
\end{tabular}




\begin{tabular}{|c|c|c|c|c|}
\hline Staffing (FTEs) & \multicolumn{4}{|l|}{-} \\
\hline $\begin{array}{l}\text { Network backbone } \\
\text { capacity }\end{array}$ & \multicolumn{4}{|c|}{$\begin{array}{l}\text { 3X STM1 (465Mbps) for commodity Internet. Proof of concept for } \\
\text { deployment of a } 1 \text { Gbps backbone with a telecom operator ongoing. } \\
\text { Applications for IP resources for GARNET and its members ongoing. }\end{array}$} \\
\hline $\begin{array}{l}\text { International REN } \\
\text { connectivity }\end{array}$ & \multicolumn{4}{|c|}{ No REN connectivity yet. Potentially through AfricaConnect 2 . } \\
\hline Services & \multicolumn{4}{|c|}{$\begin{array}{l}\text { National Information Technology Agency (NITA) offers PoP and } \\
\text { storage }\end{array}$} \\
\hline \multicolumn{5}{|l|}{ Middleware services } \\
\hline Comments & \multicolumn{4}{|c|}{$\begin{array}{l}\text { Price of commodity Internet: US\$70-200 per Mbps per month. Involved } \\
\text { in Google's Project Link for Accra (planning stage). Partner in } \\
\text { AfricaConnect2. }\end{array}$} \\
\hline Membership & \multicolumn{4}{|c|}{-} \\
\hline Type of Institution & $\begin{array}{l}\text { Allowed to serve } \\
\text { this category of } \\
\text { institution? }\end{array}$ & $\begin{array}{l}\text { Number of } \\
\text { institutions } \\
\text { connected }\end{array}$ & $\begin{array}{l}\text { Range of } \\
\text { bandwidth } \\
\text { provided }\end{array}$ & $\begin{array}{c}\text { Market } \\
\text { Share (\%) }\end{array}$ \\
\hline Universities & Yes & 25 & $\begin{array}{l}\text { Min: } 45 \\
\text { Mbps }\end{array}$ & 28 \\
\hline $\begin{array}{l}\text { Teacher training } \\
\text { colleges }\end{array}$ & Yes & - & - & - \\
\hline $\begin{array}{l}\text { Colleges of further } \\
\text { education }\end{array}$ & Yes & - & - & - \\
\hline Research institutes & Yes & - & - & - \\
\hline Secondary schools & Potentially & - & - & - \\
\hline Primary schools & Potentially & - & - & - \\
\hline $\begin{array}{l}\text { Libraries, museums, } \\
\text { cultural institutions }\end{array}$ & Yes & - & - & - \\
\hline $\begin{array}{l}\text { Hospitals (other than } \\
\text { university hospitals) }\end{array}$ & Highly potential & - & - & - \\
\hline $\begin{array}{l}\text { Government } \\
\text { departments }\end{array}$ & Maybe & - & - & - \\
\hline $\begin{array}{l}\text { For-profit } \\
\text { organizations }\end{array}$ & Maybe & - & - & - \\
\hline $\begin{array}{l}\text { International } \\
\text { organizations }\end{array}$ & Highly potential & - & - & - \\
\hline
\end{tabular}

\section{Guinea}

\begin{tabular}{|l|l|}
\hline NREN & None \\
\hline Operational status & Discussions. Level 2 development \\
\hline Date established & - \\
\hline Address & - \\
\hline Contact & - \\
\hline Comments & - \\
\hline
\end{tabular}

\section{Guinea Bissau}

\begin{tabular}{|l|l|}
\hline NREN & None \\
\hline Operational status & Discussions. Level 1 development \\
\hline Date established & - \\
\hline Address & - \\
\hline Contact & - \\
\hline
\end{tabular}




\begin{tabular}{|c|c|}
\hline Comments & - \\
\hline \multicolumn{2}{|l|}{ Liberia } \\
\hline NREN & None \\
\hline Operational status & Discussions. Level 2 development \\
\hline Date established & - \\
\hline Address & $\begin{array}{l}\text { Tubman University } \\
\text { Monrovia Office } \\
\text { Congo Town } \\
\text { P.O.Box } 3570 \\
\end{array}$ \\
\hline Contact & Tarkolo Miller: tmiller@tubmanu.edu.Ir \\
\hline Comments & - \\
\hline
\end{tabular}

\section{Mali}

\begin{tabular}{|l|l|}
\hline NREN & $\begin{array}{l}\text { MaliREN (Réseau national d'éducation et de recherche du Mali) - } \\
\text { www.maliren.ml }\end{array}$ \\
\hline Operational status & Planning. Level 3 development \\
\hline Date established & - \\
\hline Address & $\begin{array}{l}\text { Agence Nationale de Télésanté et d'Informatique Médicale } \\
\text { Ministère de la Santé } \\
\text { Rue 340, Porte 541 - ACI2000 - Bamako } \\
\text { République du Mali }\end{array}$ \\
\hline Contact & $\begin{array}{l}\text { Dr. Ousmane Ly, Directeur Général, Agence Nationale de Telesante et } \\
\text { Medicale: oussouly@maliren.ml; +223 76134470 }\end{array}$ \\
\hline Comments & World Bank proposals ongoing. Partner in AfricaConnect2. \\
\hline
\end{tabular}

\section{Niger}

\begin{tabular}{|l|l|}
\hline NREN & NigerREN - www.niger-ren.ne \\
\hline Operational status & Planning. Level 3 development \\
\hline Date established & Concertation workshop 2011, registered July 2013 \\
\hline Address & $\begin{array}{l}\text { C/O Faculté des Sciences et Techniques, Université Abdou Moumouni } \\
\text { P.O. Box 10.111 Niamey, NIGER }\end{array}$ \\
\hline Contact & $\begin{array}{l}\text { Dr. Ousmane Moussa Tessa, CEO } \\
\text { ousmane@musatesa.net; +227 96 279992 / 91 49 16 39 }\end{array}$ \\
\hline Governance & Independent non-profit organization \\
\hline $\begin{array}{l}\text { Relationship to } \\
\text { government }\end{array}$ & $\begin{array}{l}\text { Ministry of Higher Education, Research and Innovation (MESR/I) with } \\
\text { Minister for Digital Economy and SONITEL as Technical Partner } \\
\text { initiated the network with Niger-REN as master of works. }\end{array}$ \\
\hline Funding sources & $50 \%$ discount on bandwidth from Sonitel \\
\hline Operating budget & US\$12,000 for 2015 \\
\hline Staffing (FTEs) & Voluntary staff currently \\
\hline $\begin{array}{l}\text { Network backbone } \\
\text { capacity }\end{array}$ & $\begin{array}{l}\text { Not in operation yet. Interconnection of 9 institutions planned } \\
\text { (memorandum of understanding with ministry signed) }\end{array}$ \\
\hline $\begin{array}{l}\text { International REN } \\
\text { connectivity }\end{array}$ & $\begin{array}{l}\text { No REN connectivity, but collaboration with SokREN (neighboring } \\
\text { Nigerian NgREN cluster) ongoing }\end{array}$ \\
\hline Services & - \\
\hline Middleware services & - \\
\hline Comments & Partner in AfricaConnect2 \\
\hline
\end{tabular}




\begin{tabular}{|c|c|c|c|c|}
\hline Membership & - & & & \\
\hline Type of Institution & $\begin{array}{l}\text { Allowed to serve } \\
\text { this category of } \\
\text { institution? }\end{array}$ & $\begin{array}{l}\text { Number of } \\
\text { institutions } \\
\text { connected }\end{array}$ & $\begin{array}{c}\text { Range of } \\
\text { bandwidth } \\
\text { provided }\end{array}$ & $\begin{array}{c}\text { Market } \\
\text { Share (\%) }\end{array}$ \\
\hline Universities & Yes & 4 & $\begin{array}{l}1-15 \\
\text { Mbps }\end{array}$ & - \\
\hline $\begin{array}{l}\text { Teacher training } \\
\text { colleges }\end{array}$ & Yes & $\begin{array}{l}\text { Educatio } \\
\mathrm{n} \\
\text { departme } \\
\text { nts in } 4 \\
\text { universiti } \\
\text { es }\end{array}$ & - & - \\
\hline $\begin{array}{l}\text { Colleges of further } \\
\text { education }\end{array}$ & Yes & 2 & - & - \\
\hline Research institutes & Yes & 2 & $\begin{array}{l}4 \text { Mbps } \\
\text { (Sonitel } \\
\text { fiber) }\end{array}$ & - \\
\hline Secondary schools & - & - & - & - \\
\hline Primary schools & - & - & - & - \\
\hline $\begin{array}{l}\text { Libraries, museums, } \\
\text { cultural institutions }\end{array}$ & - & - & - & - \\
\hline $\begin{array}{l}\text { Hospitals (other than } \\
\text { university hospitals) }\end{array}$ & - & - & - & - \\
\hline $\begin{array}{l}\text { Government } \\
\text { departments }\end{array}$ & - & - & - & - \\
\hline $\begin{array}{l}\text { For-profit } \\
\text { organizations }\end{array}$ & - & - & - & - \\
\hline $\begin{array}{l}\text { International } \\
\text { organizations }\end{array}$ & - & - & - & - \\
\hline
\end{tabular}

\section{Nigeria}

\begin{tabular}{|c|c|}
\hline NREN & $\begin{array}{l}\text { NgREN (Nigerian Research and Education Network - } \\
\text { www.ngren.edu.ng }\end{array}$ \\
\hline Operational status & Operational. Level 4 development \\
\hline Date established & Commissioned in July 2014 \\
\hline Address & $\begin{array}{l}\text { Peter Okebukola Building, National Universities Commission, No. } 26 \\
\text { Aguiyi Ironsi Street, Maitama, }\end{array}$ \\
\hline Contact & CEO: Joshua Atah: jaatah@ngren.edu.ng; +234 8033145148 \\
\hline Governance & Independent Ltd Company owned by members \\
\hline $\begin{array}{l}\text { Relationship to } \\
\text { government }\end{array}$ & Indirect ( 6 board members are vice chancellors) \\
\hline Funding sources & World Bank US\$10 million start-up, membership and service fees \\
\hline Operating budget & - \\
\hline \multicolumn{2}{|l|}{ Staffing (FTEs) } \\
\hline $\begin{array}{l}\text { Network backbone } \\
\text { capacity }\end{array}$ & $\begin{array}{l}10 \text { Gbps backbone. 3X STM1 to Commodity Internet (US\$129 per } \\
\text { Mbps per month) }\end{array}$ \\
\hline $\begin{array}{l}\text { International REN } \\
\text { connectivity }\end{array}$ & Awaiting AfricaConnect2 for REN connectivity \\
\hline Services & $\begin{array}{l}\text { Hosting (web hosting, DNS); IP telephony platform; central video } \\
\text { conferencing services; repositories setup; network and connectivity } \\
\text { (MPLS Core transmission, Level } 2 \text { and Level } 3 \text { Network support. } \\
\text { Licensing, Internet Exchange, IPV4 and IPv6 infrastructure, BGP } \\
\text { peering), capacity building }\end{array}$ \\
\hline
\end{tabular}




\begin{tabular}{|c|c|c|c|c|}
\hline Middleware services & \multicolumn{4}{|l|}{-} \\
\hline Comments & \multicolumn{4}{|c|}{$\begin{array}{l}10 \text { Gbps backbone. Last mile by wireless in increments of } 155 \mathrm{Mbps} \text {. } \\
\text { Good cost comparisons NgREN versus market. } 102 \text { other universities } \\
\text { and } 17 \text { teaching hospitals to be connected within the next year. Partner } \\
\text { in AfricaConnect2. }\end{array}$} \\
\hline \multicolumn{5}{|c|}{ 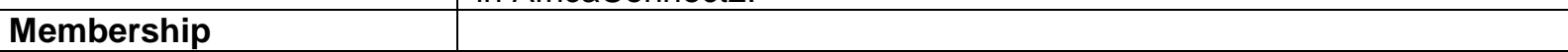 } \\
\hline Type of Institution & $\begin{array}{l}\text { Allowed to serve } \\
\text { this category of } \\
\text { institution? }\end{array}$ & $\begin{array}{l}\text { Number of } \\
\text { institutions } \\
\text { connected }\end{array}$ & $\begin{array}{c}\text { Range of } \\
\text { bandwidth } \\
\text { provided }\end{array}$ & $\begin{array}{c}\text { Market } \\
\text { Share (\%) }\end{array}$ \\
\hline Universities & Yes & 27 & $\begin{array}{l}\text { 155Mbps } \\
\text { Basic in } \\
\text { STM } 1 \\
\text { incremen } \\
\text { ts }\end{array}$ & $\begin{array}{l}\text { Risi } \\
\text { ng } \\
\text { to } \\
100\end{array}$ \\
\hline $\begin{array}{l}\text { Teacher training } \\
\text { colleges }\end{array}$ & Yes & 0 & - & - \\
\hline $\begin{array}{l}\text { Colleges of further } \\
\text { education }\end{array}$ & Yes & 0 & - & - \\
\hline Research institutes & yes & 0 & - & - \\
\hline Secondary schools & Yes & 0 & - & - \\
\hline Primary schools & Yes & 0 & - & - \\
\hline $\begin{array}{l}\text { Libraries, museums, } \\
\text { cultural institutions }\end{array}$ & Yes & 0 & - & - \\
\hline $\begin{array}{l}\text { Hospitals (other than } \\
\text { university hospitals) }\end{array}$ & Yes & 17 & - & - \\
\hline $\begin{array}{l}\text { Government } \\
\text { departments }\end{array}$ & Yes & 1 & - & - \\
\hline $\begin{array}{l}\text { For-profit } \\
\text { organizations }\end{array}$ & No & & - & - \\
\hline $\begin{array}{l}\text { International } \\
\text { organizations }\end{array}$ & Yes & 0 & - & - \\
\hline
\end{tabular}

\section{São Tomé and Príncipe}

\begin{tabular}{|l|l|}
\hline NREN & None \\
\hline Operational status & No known activity. Level 0 development \\
\hline Date established & - \\
\hline Address & - \\
\hline Contact & - \\
\hline
\end{tabular}

\section{Senegal}

\begin{tabular}{|l|l|}
\hline NREN & $\begin{array}{l}\text { SnRER (Réseau pour l'Enseignement supérieur et la Recherche du } \\
\text { Séné gal) - http://snrer.edu.sn }\end{array}$ \\
\hline Operational status & Operational - Level 4 development \\
\hline Date established & March 2011 \\
\hline Address & $\begin{array}{l}\text { S/c Ministère de l'Enseignement Supérieur et la Recherche du Sénégal } \\
\text { 3ème étage - Immeuble Adja Fatou Nourou Diop - Allées Papa Gueye } \\
\text { Fall }\end{array}$ \\
\hline Contact & $\begin{array}{l}\text { Dr. Ibrahima Niang: iniang@ucad.sn, } \\
\text { Dr. Alex Corenthin: corenthin@ucad.sn UCAD Dakar }\end{array}$ \\
\hline Governance & - \\
\hline $\begin{array}{l}\text { Relationship to } \\
\text { government }\end{array}$ & - \\
\hline
\end{tabular}




\begin{tabular}{|c|c|c|c|c|}
\hline Funding sources & \multicolumn{4}{|c|}{ World Bank (IDA) for campus networks in 5 universities } \\
\hline Operating budget & \multicolumn{4}{|c|}{-} \\
\hline Staffing (FTEs) & \multicolumn{4}{|l|}{-} \\
\hline $\begin{array}{l}\text { Network backbone } \\
\text { capacity }\end{array}$ & \multicolumn{4}{|l|}{ STM-1 (155 Mbps) } \\
\hline $\begin{array}{l}\text { International REN } \\
\text { connectivity }\end{array}$ & \multicolumn{4}{|c|}{$\begin{array}{l}\text { International connectivity procured (Internet access for now). Awaiting } \\
\text { AfricaConnect2 for REN connectivity. SnRER will host the WACREN } \\
\text { NOC when the other member NRENs are connected to each other. }\end{array}$} \\
\hline Services & \multicolumn{4}{|c|}{ Currently only connectivity and videoconferencing } \\
\hline Middleware services & \multicolumn{4}{|c|}{-} \\
\hline Comments & \multicolumn{4}{|c|}{ Potential link to Paris. Partner in AfricaConnect2 } \\
\hline Membership & \multicolumn{4}{|c|}{ - } \\
\hline Type of Institution & $\begin{array}{l}\text { Allowed to serve } \\
\text { this category of } \\
\text { institution? }\end{array}$ & $\begin{array}{l}\text { Number of } \\
\text { institutions } \\
\text { connected }\end{array}$ & $\begin{array}{c}\text { Range of } \\
\text { bandwidth } \\
\text { provided }\end{array}$ & $\begin{array}{c}\text { Market } \\
\text { Share (\%) }\end{array}$ \\
\hline Universities & Yes & 5 & - & - \\
\hline $\begin{array}{l}\text { Teacher training } \\
\text { colleges }\end{array}$ & Yes & - & - & - \\
\hline $\begin{array}{l}\text { Colleges of further } \\
\text { education }\end{array}$ & Yes & - & - & - \\
\hline Research institutes & Yes & - & - & - \\
\hline Secondary schools & - & - & - & - \\
\hline Primary schools & - & - & - & - \\
\hline $\begin{array}{l}\text { Libraries, museums, } \\
\text { cultural institutions }\end{array}$ & - & - & - & - \\
\hline $\begin{array}{l}\text { Hospitals (other than } \\
\text { university hospitals) }\end{array}$ & - & - & - & - \\
\hline $\begin{array}{l}\text { Government } \\
\text { departments }\end{array}$ & - & - & - & - \\
\hline $\begin{array}{l}\text { For-profit } \\
\text { organizations }\end{array}$ & - & - & - & - \\
\hline $\begin{array}{l}\text { International } \\
\text { organizations }\end{array}$ & - & - & - & - \\
\hline
\end{tabular}

\section{Sierra Leone}

\begin{tabular}{|l|l|}
\hline NREN & SLREN \\
\hline Operational status & Planning. Level 2 development \\
\hline Date established & - \\
\hline Address & Njala University \\
& $\begin{array}{l}\text { Njala Campus } \\
\text { Private Mail Bag } \\
\text { Freetown } \\
\text { Sierra Leone }\end{array}$ \\
\hline Contact & Thomas Philip Songu: tsongu@njala.edu.s! \\
\hline Comments & $\begin{array}{l}\text { First meeting of stakeholders in Njala University on 26 } \\
\text { Adoption of the Njala Declaration on the establishment of the Sierra } \\
\text { Leone Research and Education Network (SLREN) and the creation of } \\
\text { an interim committee charged with the registration of the SLREN and } \\
\text { proposing management and governance structure within 3 months. }\end{array}$ \\
\hline
\end{tabular}




\section{Togo}

\begin{tabular}{|c|c|c|c|c|}
\hline NREN & \multicolumn{4}{|c|}{$\begin{array}{l}\text { TogoRER (Réseau d'Education et de Recherche du Togo) - } \\
\text { http://rer.togorer.tg/ }\end{array}$} \\
\hline Operational status & \multicolumn{4}{|c|}{ Planning. Level 3 development } \\
\hline Date established & \multicolumn{4}{|c|}{-} \\
\hline Address & \multicolumn{4}{|c|}{ BP 1515, Université de Lomé, centre Informatique et de Calcul } \\
\hline Contact & \multicolumn{4}{|c|}{ Venant Palanga: venant.palanga@wacren.net; +228 90171260} \\
\hline Governance & \multicolumn{4}{|c|}{ Independent entity } \\
\hline $\begin{array}{l}\text { Relationship to } \\
\text { government }\end{array}$ & \multicolumn{4}{|c|}{$\begin{array}{l}\text { No formal relationship, but works with Ministry of Education, seeking } \\
\text { funding (some buy-in) }\end{array}$} \\
\hline Funding sources & \multicolumn{4}{|c|}{ None } \\
\hline Operating budget & \multicolumn{4}{|l|}{ - } \\
\hline Staffing (FTEs) & \multicolumn{4}{|c|}{ All voluntary } \\
\hline $\begin{array}{l}\text { Network backbone } \\
\text { capacity }\end{array}$ & \multicolumn{4}{|c|}{ None. All institutions are connected to commodity Internet } \\
\hline $\begin{array}{l}\text { International REN } \\
\text { connectivity }\end{array}$ & \multicolumn{4}{|l|}{ None } \\
\hline Services & \multicolumn{4}{|c|}{ Videoconferencing in 2 universities (for meetings) } \\
\hline Middleware services & \\
\hline Comments & \multicolumn{4}{|c|}{$\begin{array}{l}\text { Some progress noticed (organizational, and buy-in of authorities). } \\
\text { Possible support from African Development Bank (AfDB) }\end{array}$} \\
\hline Membership & \multicolumn{4}{|c|}{ - } \\
\hline Type of Institution & $\begin{array}{l}\text { Allowed to serve } \\
\text { this category of } \\
\text { institution? }\end{array}$ & $\begin{array}{l}\text { Number of } \\
\text { institutions } \\
\text { connected }\end{array}$ & $\begin{array}{c}\text { Range of } \\
\text { bandwidth } \\
\text { provided }\end{array}$ & $\begin{array}{l}\text { Market } \\
\text { Share (\%) }\end{array}$ \\
\hline Universities & Yes & 3 & $\begin{array}{l}2-15 \\
\text { Mbps }\end{array}$ & - \\
\hline $\begin{array}{l}\text { Teacher training } \\
\text { colleges }\end{array}$ & Yes & 0 & - & - \\
\hline $\begin{array}{l}\text { Colleges of further } \\
\text { education }\end{array}$ & Yes & 2 & $512 \mathrm{kbps}$ & - \\
\hline Research institutes & Yes & 1 & $512 \mathrm{kbps}$ & - \\
\hline Secondary schools & Yes & 0 & - & - \\
\hline Primary schools & Yes & 0 & - & - \\
\hline $\begin{array}{l}\text { Libraries, museums, } \\
\text { cultural institutions }\end{array}$ & Yes & - & - & - \\
\hline $\begin{array}{l}\text { Hospitals (other than } \\
\text { university hospitals) }\end{array}$ & Yes & - & - & - \\
\hline $\begin{array}{l}\text { Government } \\
\text { departments }\end{array}$ & Yes & - & - & - \\
\hline $\begin{array}{l}\text { For-profit } \\
\text { organizations }\end{array}$ & Yes & $\begin{array}{l}1 \\
\text { (Groupe } \\
\text { ESIBA }\end{array}$ & $512 \mathrm{Kbps}$ & - \\
\hline $\begin{array}{l}\text { International } \\
\text { organizations }\end{array}$ & Yes & - & - & - \\
\hline
\end{tabular}




\section{North Africa - ASREN Region}

\section{ASREN (Arab States Research and Education Network)}

Talal Abu-Ghazaleh University Company building (TAGIUNI)

No. 45, Abdel Rahim Al- Waked Street, Shmeisani, near Le Meridien Amman Hotel

Address: P.O.Box: 921100, Amman 11192 Jordan

Contacts: $\quad$ Yousef Torman: torman@asrenorg.net

Salem Al-Agtash: alagtash@asrenorg.net

Phone: + 962-6 5100900

E-mail: info@asrenorg.net

Algeria

\begin{tabular}{|c|c|c|c|c|}
\hline NREN & \multicolumn{4}{|c|}{$\begin{array}{l}\text { CERIST (Centre de Recherche surl'Information Scientifique et } \\
\text { Technique) - www.arn.dz }\end{array}$} \\
\hline Operational status & \multicolumn{4}{|c|}{ Operational. Level 6 development } \\
\hline Date established & \multicolumn{4}{|c|}{ Early 1990s. Current network since early 2011} \\
\hline Address & \multicolumn{4}{|c|}{ Rue des Trois Frères Aissou Ben Aknoun 16030 Algiers, Algeria } \\
\hline Contact & \multicolumn{4}{|c|}{ Aouaouche El-Maouhab +213 (0)21 9154 34. ceristdir@cerist.dz } \\
\hline Governance & \multicolumn{4}{|l|}{ - } \\
\hline $\begin{array}{l}\text { Relationship to } \\
\text { government }\end{array}$ & \multicolumn{4}{|l|}{-} \\
\hline Funding sources & \multicolumn{4}{|c|}{ Members fees, services } \\
\hline Operating budget & \multicolumn{4}{|l|}{ - } \\
\hline Staffing (FTEs) & \\
\hline $\begin{array}{l}\text { Network backbone } \\
\text { capacity }\end{array}$ & \multicolumn{4}{|c|}{ Algeria Telecom provides the connectivity } \\
\hline $\begin{array}{l}\text { International REN } \\
\text { connectivity }\end{array}$ & \multicolumn{4}{|c|}{ 2.5Gbps to GÉANT, $777 \mathrm{Mbps}$ to Commodity Internet } \\
\hline Services & \multicolumn{4}{|c|}{$\begin{array}{l}\text { IPv4 and IPv6 connectivity, .dz naming (DZ-NIC), multicasting, mail, } \\
\text { web hosting, videoconferencing, grid computing (DZ e-Science GRID) }\end{array}$} \\
\hline Middleware services & \multicolumn{4}{|c|}{ DNS, authentication for Science gateway } \\
\hline Comments & \multirow{2}{*}{\multicolumn{4}{|c|}{$\begin{array}{ll}\text { AUP } \\
-\end{array}$}} \\
\hline Membership & & & & \\
\hline Type of Institution & $\begin{array}{l}\text { Allowed to serve } \\
\text { this category of } \\
\text { institution? }\end{array}$ & $\begin{array}{l}\text { Number of } \\
\text { institutions } \\
\text { connected }\end{array}$ & $\begin{array}{c}\text { Range of } \\
\text { bandwidth } \\
\text { provided }\end{array}$ & $\begin{array}{l}\text { Market } \\
\text { Share (\%) }\end{array}$ \\
\hline $\begin{array}{l}\text { Universities and } \\
\text { university centers }\end{array}$ & Yes & 63 & $\begin{array}{l}\text { 10-100 } \\
\text { Mbps }\end{array}$ & - \\
\hline $\begin{array}{l}\text { Teacher training } \\
\text { colleges }\end{array}$ & Yes & - & - & - \\
\hline $\begin{array}{l}\text { Ecoles Nationales } \\
\text { Superieures }\end{array}$ & Yes & 21 & - & - \\
\hline $\begin{array}{l}\text { Ecoles Normales } \\
\text { Supérieures }\end{array}$ & Yes & 7 & - & - \\
\hline Research institutes & Yes & 13 & - & - \\
\hline Secondary schools & Yes & & - & - \\
\hline Primary schools & Yes & 12 & - & - \\
\hline Other institutions & Yes & 17 & - & - \\
\hline
\end{tabular}




\begin{tabular}{|l|l|l|l|l|}
\hline $\begin{array}{l}\text { Hospitals (other than } \\
\text { university hospitals) }\end{array}$ & Yes & $\begin{array}{l}\text { 1 Ministry } \\
\text { of Higher } \\
\text { Educatio } \\
\text { n and } \\
\text { Research } \\
\text { (MESRS) }\end{array}$ & - & - \\
\hline $\begin{array}{l}\text { Government } \\
\text { departments }\end{array}$ & - & - & - & - \\
\hline $\begin{array}{l}\text { For-profit } \\
\text { organizations }\end{array}$ & - & - & - & - \\
\hline $\begin{array}{l}\text { International } \\
\text { organizations }\end{array}$ & - & & - \\
\hline
\end{tabular}

\section{Egypt}

\begin{tabular}{|c|c|c|c|c|}
\hline NREN & \multicolumn{4}{|c|}{ EUN - www.eun.eg } \\
\hline Operational status & \multicolumn{4}{|c|}{ Operational. Level 6 development } \\
\hline Date established & \multicolumn{4}{|c|}{1987} \\
\hline Address & \multicolumn{4}{|c|}{$\begin{array}{l}2613 \text { Giza - PO Box } 268 \\
\text { Egypt Supreme Council of Universities Building, Cairo University } \\
\text { Campus }\end{array}$} \\
\hline Contact & \multicolumn{4}{|c|}{ Ahmad Hassan: ahassan@scu.eg. Tel: +202 377423 47/8 } \\
\hline Governance & \multicolumn{4}{|c|}{-} \\
\hline $\begin{array}{l}\text { Relationship to } \\
\text { government }\end{array}$ & \multicolumn{4}{|l|}{-} \\
\hline Funding sources & \multicolumn{4}{|l|}{ - } \\
\hline Operating budget & \multicolumn{4}{|l|}{-} \\
\hline Staffing (FTEs) & \multicolumn{4}{|l|}{ - } \\
\hline $\begin{array}{l}\text { Network backbone } \\
\text { capacity }\end{array}$ & \multicolumn{4}{|l|}{-} \\
\hline $\begin{array}{l}\text { International REN } \\
\text { connectivity }\end{array}$ & \multicolumn{4}{|c|}{1 Gbps link to Internet2 through Gloriad, 1 Gbps Commodity Internet } \\
\hline Services & \multicolumn{4}{|c|}{$\begin{array}{l}\text { Operating .eg domain, e-library, e-mail, hosting, videoconference, } \\
\text { HEMIS, campus networks consulting, }\end{array}$} \\
\hline Middleware services & \multicolumn{4}{|c|}{ DNS, IPv6, security and authentication } \\
\hline Comments & \multirow{2}{*}{\multicolumn{4}{|c|}{ - }} \\
\hline Membership & & & & \\
\hline Type of Institution & $\begin{array}{l}\text { Allowed to serve } \\
\text { this category of } \\
\text { institution? }\end{array}$ & $\begin{array}{l}\text { Number of } \\
\text { institutions } \\
\text { connected }\end{array}$ & $\begin{array}{c}\text { Range of } \\
\text { bandwidth } \\
\text { provided }\end{array}$ & $\begin{array}{c}\text { Market } \\
\text { Share (\%) }\end{array}$ \\
\hline Universities & Yes & 18 & - & - \\
\hline Private universities & Yes & 12 & - & - \\
\hline $\begin{array}{l}\text { Teacher training } \\
\text { colleges }\end{array}$ & - & - & - & - \\
\hline $\begin{array}{l}\text { Colleges of further } \\
\text { education }\end{array}$ & - & - & - & - \\
\hline Research institutes & - & - & - & - \\
\hline Secondary schools & - & - & - & - \\
\hline Primary schools & - & - & - & - \\
\hline $\begin{array}{l}\text { Libraries, museums, } \\
\text { cultural institutions }\end{array}$ & - & - & - & - \\
\hline $\begin{array}{l}\text { Hospitals (other than } \\
\text { university hospitals) }\end{array}$ & - & - & - & - \\
\hline $\begin{array}{l}\text { Government } \\
\text { departments }\end{array}$ & - & - & - & - \\
\hline
\end{tabular}




\begin{tabular}{|l|c|l|l|l|}
\hline $\begin{array}{l}\text { For-profit } \\
\text { organizations }\end{array}$ & - & - & - & - \\
\hline $\begin{array}{l}\text { International } \\
\text { organizations }\end{array}$ & - & - & - & - \\
\hline
\end{tabular}

\section{Djibouti}

\begin{tabular}{|l|l|}
\hline NREN & None \\
\hline Operational status & Status unknown. Level 0 development \\
\hline Date established & - \\
\hline Address & - \\
\hline Contact & - \\
\hline
\end{tabular}

\section{Libya}

\begin{tabular}{|l|l|}
\hline NREN & LibREN \\
\hline Operational status & Status unknown due to conflict. Level 1 development \\
\hline Date established & - \\
\hline Address & - \\
\hline Contact & - \\
\hline Comments & Discussions with government in 2011, but no solid action yet \\
\hline
\end{tabular}

\section{Mauritania}

\begin{tabular}{|l|l|}
\hline NREN & None \\
\hline Operational status & Planning - Level 2 development \\
\hline Date established & - \\
\hline Address & - \\
\hline Contact & Ahmedou Haouba, President - University of Science, Technology and \\
& Medicine: +222 22 46 8317 \\
& Mohamed Lemine Salihi , Director of Information Technology and \\
& communication - Department of Employment, Vocational Training and \\
& New Technologies: +222 45 29 07 24 \\
\hline
\end{tabular}

\section{Morocco}

\begin{tabular}{|l|l|}
\hline NREN & $\begin{array}{l}\text { MARWAN (Moroccan Academic and Research Wide Area Network)- } \\
\text { http://www.cnr.ac.ma }\end{array}$ \\
\hline Operational status & Operational - Level 5 development \\
\hline Date established & 1998. MARWAN 3 updated network being implemented \\
\hline Address & $\begin{array}{l}\text { Angle avenue Allal El Fassi, avenue des FAR, Hay Ryad, BP. } 8027 \\
\text { NU, 10102, Rabat }\end{array}$ \\
\hline Contact & Driss Aboutajdine: aboutaj@hotmail.com. +212 537 56 98 00. \\
\hline Governance & $\begin{array}{l}\text { Operated by National Center for Scientific and Technical Research } \\
\text { (CNRST) }\end{array}$ \\
\hline $\begin{array}{l}\text { Relationship to } \\
\text { government }\end{array}$ & - \\
\hline Funding sources & - \\
\hline Operating budget & - \\
\hline Staffing (FTEs) & - \\
\hline $\begin{array}{l}\text { Network backbone } \\
\text { capacity }\end{array}$ & $\begin{array}{l}\text { Built by Meditel. Connectivity of 2-100 Mbps to universities. } \\
\text { Commodity Internet provided by Meditel }\end{array}$ \\
\hline
\end{tabular}




\begin{tabular}{|l|l|l|l|l|}
\hline $\begin{array}{l}\text { International REN } \\
\text { connectivity }\end{array}$ & \multicolumn{3}{|l|}{ 1Gbps to GÉANT planned for AfricaConnect2 } \\
\hline Services & \multicolumn{4}{|l|}{ Grid, videoconferencing, Virtual campus } \\
\hline Middleware services & \multicolumn{2}{|l|}{ EDU-CERT and eduroam authentication } \\
\hline Comments & MARWAN 4 tendered for - planned operational July 2016 \\
\hline Membership & - & $\begin{array}{l}\text { Range of } \\
\text { bandwidth } \\
\text { provided }\end{array}$ & $\begin{array}{c}\text { Market } \\
\text { Share (\%) }\end{array}$ \\
\hline Type of Institution & $\begin{array}{l}\text { Allowed to serve } \\
\text { this category of } \\
\text { institution? }\end{array}$ & $\begin{array}{l}\text { institutions } \\
\text { connected }\end{array}$ & - & - \\
\hline Universities & - & - & - & - \\
\hline $\begin{array}{l}\text { Teacher training } \\
\text { colleges }\end{array}$ & - & - & - & - \\
\hline $\begin{array}{l}\text { Colleges of further } \\
\text { education }\end{array}$ & - & - & - & - \\
\hline Research institutes & - & - & - & - \\
\hline Secondary schools & - & - & - & - \\
\hline Primary schools & - & - & - & - \\
\hline $\begin{array}{l}\text { Libraries, museums, } \\
\text { cultural institutions }\end{array}$ & - & - & - & - \\
\hline $\begin{array}{l}\text { Hospitals (other than } \\
\text { university hospitals) }\end{array}$ & - & - & - & - \\
\hline $\begin{array}{l}\text { Government } \\
\text { departments }\end{array}$ & - & - & - & - \\
\hline $\begin{array}{l}\text { For-profit } \\
\text { organizations }\end{array}$ & - & - & - & - \\
\hline $\begin{array}{l}\text { International } \\
\text { organizations }\end{array}$ & - & - & - \\
\hline
\end{tabular}

\section{Tunisia}

\begin{tabular}{|c|c|c|c|c|}
\hline NREN & \multicolumn{4}{|c|}{ CCK (Computing Center Al Khwarizmi) - www.cck.rnu.tn } \\
\hline Operational status & \multicolumn{4}{|c|}{ Operational. Level 4 (was at 6 until conflicts) development } \\
\hline Date established & \multicolumn{4}{|c|}{1997} \\
\hline Address & \multicolumn{4}{|c|}{ University campus of the Manouba 2010, Tunisia } \\
\hline Contact & \multicolumn{4}{|c|}{ Youssef Habib: habib.youssef@cck.rnu.tn . +216 71602840} \\
\hline Governance & \multicolumn{4}{|c|}{ Operated by CCK } \\
\hline $\begin{array}{l}\text { Relationship to } \\
\text { government }\end{array}$ & \multicolumn{4}{|l|}{-} \\
\hline Funding sources & \multicolumn{4}{|l|}{ - } \\
\hline Operating budget & \multicolumn{4}{|l|}{ - } \\
\hline Staffing (FTEs) & \multicolumn{4}{|l|}{ - } \\
\hline $\begin{array}{l}\text { Network backbone } \\
\text { capacity }\end{array}$ & \multicolumn{4}{|c|}{20 Gbps fiber backbone } \\
\hline $\begin{array}{l}\text { International REN } \\
\text { connectivity }\end{array}$ & \multicolumn{4}{|c|}{$\begin{array}{l}\text { Connected to GÉANT until 2011. Reconnecting in AfricaConnect2 at } \\
\text { 1Gbps }\end{array}$} \\
\hline Services & \multicolumn{4}{|c|}{$\begin{array}{l}\text { Data center, email, Telnet, FTP, web hosting, e-learning, library } \\
\text { services (BIRUNI) }\end{array}$} \\
\hline Middleware services & \multicolumn{4}{|c|}{ Security } \\
\hline Comments & \multicolumn{4}{|l|}{-} \\
\hline Membership & \multicolumn{4}{|l|}{500 sites connected } \\
\hline Type of Institution & $\begin{array}{l}\text { Allowed to serve } \\
\text { this category of } \\
\text { institution? }\end{array}$ & $\begin{array}{l}\text { Number of } \\
\text { institutions } \\
\text { connected }\end{array}$ & $\begin{array}{l}\text { Range of } \\
\text { bandwidth } \\
\text { provided }\end{array}$ & $\begin{array}{l}\text { Market } \\
\text { Share (\%) }\end{array}$ \\
\hline Universities & yes & 13 & - & - \\
\hline
\end{tabular}




\begin{tabular}{|c|c|c|c|c|}
\hline $\begin{array}{l}\text { Teacher training } \\
\text { colleges }\end{array}$ & - & - & - & - \\
\hline $\begin{array}{l}\text { Colleges of further } \\
\text { education }\end{array}$ & Yes & - & - & - \\
\hline Research institutes & Yes & - & - & - \\
\hline Secondary schools & - & - & - & - \\
\hline Primary schools & - & - & - & - \\
\hline $\begin{array}{l}\text { Libraries, museums, } \\
\text { cultural institutions }\end{array}$ & - & - & - & - \\
\hline $\begin{array}{l}\text { Hospitals (other than } \\
\text { university hospitals) }\end{array}$ & - & - & - & - \\
\hline $\begin{array}{l}\text { Government } \\
\text { departments }\end{array}$ & - & - & - & - \\
\hline $\begin{array}{l}\text { For-profit } \\
\text { organizations }\end{array}$ & - & - & - & - \\
\hline $\begin{array}{l}\text { International } \\
\text { organizations }\end{array}$ & - & - & - & - \\
\hline
\end{tabular}




\section{Annex B. AfricaConnect Projects}

\section{AfricaConnect, Phase One: May 2010-June 2015}

\section{Project Scope}

The AfricaConnect project, starting in May 2011 for four years until June 2015, was jointly managed by DANTE and UbuntuNet Alliance. The partners were:

- DANTE,

- The UbuntuNet Alliance, representing the NRENs of East and Southern Africa (Democratic Republic of Congo, Ethiopia, Kenya, Malawi, Mozambique, Namibia, Rwanda, Somalia, Sudan, South Africa, Tanzania, Uganda and Zambia),

- WACREN, the West and Central Africa regional REN representing the emerging West and Central African NRENs, and

- European NRENs (Germany, Ireland, Italy, the Netherlands and Portugal).

The total budget for the project was $€ 14.75$ million, with 80 percent ( $€ 11.8$ million) of the funding provided by the European Development Fund and 20 percent ( $€ 2.95$ million) as the contribution from participating African countries. Building on a roadmap by the FEAST report the aim of AfricaConnect was to connect national research networks to a regional UbuntuNet backbone and from it to GÉANT in Europe, which provides onward connectivity to other regions. It also supported the establishment of a secretariat for WACREN. In the course of phase two of the AfricaConnect project, starting July 2015, the NRENs in West and Central Africa (members of WACREN) and those in North Africa (members of ASREN) are to be connected in similar fashion.

The project has procured long-term assets (undersea capacity) from West Indian Ocean Cable Company WIOCC on the EASSy and SEACOM cable systems, and terrestrial capacity from various providers, interconnecting Europe and the coastal cities of Southern and Eastern Africa. Existing PoPs have been upgraded in London and Amsterdam and more have been established in Africa at Nairobi, Dar es Salaam, Kampala, Kigali, Lusaka, Maputo, Mtunzini, Cape Town, and Moanda, serving the following NRENs: TENET (South Africa), MoRENet (Mozambique), TERNET (Tanzania), KENET (Kenya), RENU (Uganda), RwEdNet (Rwanda), Eb@le (DRC), and ZAMREN (Zambia). Equipment and high-capacity cross-border links have been procured forming the backbone on which the network to serve the entire UbuntuNet Alliance region will be created.

Procurement of equipment and installation of high-capacity cross-border links connecting the NRENs of Eb@le (Democratic Republic of Congo), MAREN (Malawi) and a redundant link interconnecting ZAMREN and TENET are to be completed in the near future.

The 80/20 funding split was applied to the procurement of bandwidth capacity to Europe, with each participating country NREN paying €280,000 as a down payment for discounted international bandwidth. 


\section{AfricaConnect, Phase Two: July 2015-December 2018 Project Scope ${ }^{59}$}

The next phase of EU support to the NRENs in Africa will come through the AfricaConnect2 - a $€ 26.6$ million pan-African project, of which $€ 20$ million will be co-funded by the EC's DirectorateGeneral International Cooperation and Development. ${ }^{60}$

The project will be for a three-and-a-half-year period from July 2015 to December 2018 covering the three clusters of NRENs corresponding to the regional associations of ASREN, WACREN, and the UbuntuNet Alliance.

Taking account of the geographical, cultural, and organizational context of the African regions and their different stages of NREN development, as well as their sources of funding, a modular approach is being adopted. For the Eastern and Southern cluster the project will be contracted directly between the EC and UbuntuNet Alliance. For West and Central Africa it will be contracted between the EC and GÉANT with leadership provided through WACREN. For North Africa, the project will follow on from the EUMEDCONNECT project and it will be contracted between the EC and GÉANT with leadership provided through ASREN.

Funding ratios for the different regions will be:

- Eastern and Southern Africa - 75:25

- West and Central Africa - 80:20

- $\quad$ North Africa - 60:40

\section{Eastern and Southern Africa}

For Eastern and Southern Africa the project aims to:

a) Consolidate and improve the UbuntuNet network by providing new e-infrastructure services and connections with new countries such as Angola, Botswana, Comoros Islands, Djibouti, Eritrea, Lesotho, Mauritius, Seychelles, South Sudan, Swaziland, and Zimbabwe as soon as they are ready to join.

b) Roll out eduroam along with AAls and training.

\section{West and Central Africa}

In West and Central Africa the AfricaConnect2 project feasibility study concluded that Benin, Côte d'Ivoire, Cameroon, Gabon, Ghana, Nigeria, Senegal, and Togo have the necessary NREN structures to participate in a geographic extension of the AfricaConnect2 project. The study also concluded that the user base in universities and colleges in these countries is very large and the demand for connectivity very high. With regard to applications, Internet access, and learning content are regarded as the most important requirement, followed by access to a scientific computing environment such as grid computing and virtual laboratories.

The aim of the project in the WACREN region is to select a minimum of three NRENs, based on legal and technical criteria, and to connect them into a regional terrestrial network and to GÉANT

${ }^{59}$ Information provided by GÉANT.

${ }^{60}$ Directorate-General International Cooperation and Development (DG DEVCO). 
via a direct connection between the region and a PoP in Europe. This initial network will aim to build a pool of skilled staff that will assist other emerging NRENs in the region with capacity building, training and technical support, and encourage them to join in a phased manner over the period of the project. This West and Central African network will also be interconnected with the UbuntuNet network in Southern and Eastern Africa in a PoP based in Africa, if justified and affordable within the overall AfricaConnect2 budget.

The WACREN secretariat is preparing for AfricaConnect2 by working with member NRENs in supporting their readiness to benefit from the financial support and the possible international connectivity it will bring. The primary support is with advocacy efforts to help them to generate their counterpart funding (€250,000 per NREN) from members, government, or other financing sources.

\section{North Africa}

North Africa has some well-established NRENs and a strong regional partner, ASREN. EUMEDCONNECT has provided a regional network since 2004 for Northern Africa and the Middle East. Following the Arab spring, only Algeria is currently connected, some of the partners having had to disconnect temporarily from EUMEDCONNECT as they rebuild their relationships with their government ministries and funding agencies. Egypt has identified an alternative international connectivity, outside EUMEDCONNECT, with a direct interconnection to GÉANT. The situation in Libya is unknown. In the context of AfricaConnect2, the North African EUMEDCONNECT3 partner countries (Algeria, Egypt, Morocco, and Tunisia) will migrate into the pan-African program with a higher EC co-funding share (60 percent as opposed to 36 percent within EUMEDCONNECT3).

Connectivity options will also be implemented between all three regions as well as direct links to the GÉANT network. 


\section{Annex C. Capacity-Building Programs and Projects Supporting NREN Services Development in Africa}

\section{TANDEM (Trans African Network Development)}

The project aims to create favorable conditions for WACREN to be able to participate in the forthcoming AfricaConnect project extension and to draw maximum benefit from it. The focus will be on research topics such as health, food security, the environment, connectivity, and the implementation of global e-infrastructure services such as:

- Connectivity services (IP, VPNs, DNS, and so on);

- Mobility and authentication services (for example, eduroam, identity federations, certificates);

- Applications which give access to data repositories, data visualization tools, computing grids, and so on;

- Collaboration tools, for example, web-conferencing, file transfer, user group management tools, meeting management tools, wiki, and so on.

The project duration is for two years and the partners include IRD, WACREN, GÉANT, RENATER, CIRAD, Sigma Orionis, Brunel University, UbuntuNet Alliance, and RedCLARA.

\section{MAGIC (Middleware for Collaborative Applications and Global Virtual Communities)}

The MAGIC Project seeks to establish a set of agreements for Europe, Latin America and the Caribbean, Africa, and Asia, aiming at consolidating and completing the building blocks of middleware necessary for the establishment of a marketplace of services and real-time applications for international and inter-continental research groups which facilitates mobility of researchers and students and the work of global science communities.

MAGIC will focus on expanding training and deployment of eduroam and identity federation (with integration into eduGAIN within the regional networks at the heart of the project), a model for inter-operation between NREN cloud application markets and real-time application interoperability.

\section{Sci-GalA (Energizing Scientific Endeavour through Science Gateways ${ }^{\natural 1}$ and e-Infrastructures in Africa)}

Coordinated by Brunel University (United Kingdom), Sci-GalA aims at creating a sustainable foundation of educational materials and procedures for the development, management, and editing of Science Gateways and e-infrastructures in Africa and beyond. The project approach is based around three objectives:

${ }^{61}$ A science gateway is a web-based interface to allow science teams to access data, perform shared computations, and generally interact with group resources over the web 
- Promote the uptake of Science Gateways and e-infrastructures in Africa and beyond;

- Support new and already emerging user communities by helping the users of these technologies communicate and share experiences and information;

- Strengthen and expand Science Gateways and e-Infrastructures related services.

The project is led by Brunel University (UK) with four European and four African partners: Sigma Orionis (France), Karolinska Institutet (Sweden), University of Catania (Italy), KTH Royal Institute of Technology (Sweden), UbuntuNet Alliance, WACREN, Dar es Salaam Institute of Technology, and CSIR Council for Scientific Research (South Africa).

\section{Cyber Security - AfricaProtect - African Cyber Security Research and Threat Intelligence Collective}

AfricaProtect builds on the Africa Training Initiative to provide a framework for building capacity to make African networks cyber resilient by extending knowledge and enhancing skills in cyber security.

\section{Authentication and Authorization Infrastructures}

As the demand for researchers and research projects increases and international collaboration becomes the norm, so does the need for NRENs to provide effective, secure AAls.

By offering AAls, NRENs can provide essential value added services so that users can also take advantage of services and facilities offered by other NRENs. From ubiquitous eduroam access to advanced cloud computing platforms such as - Okeanos global, AAI is an essential enabler for collaboration. It is not only individual research users that benefit from AAI. Service providers can offer their services to a much wider audience making their platforms more cost-effective and identity providers can dramatically reduce their workload as they no longer need to maintain identities of temporary or visiting researchers and staff. With users, service providers, and identity providers all benefiting from AAI, it is important that NRENs, large international projects, and institutions need to be positioned to support these requirements.

Yet despite the benefits of AAI, nearly half of all GÉANT partners don't yet have an identity federation. This is not only restricting the ability of their users to gain access to services but could increase costs within the NREN. To tackle this challenge GÉANT developed what they call Federation as a Service (FaaS).

\section{FaaS - Enabling NRENs to Operate An Identity Federation}

The development of a national identity federation is a complex operation and so GÉANT's FaaS task was created specially to help these NRENs and other groups that did not have the capacity to establish their own identity federations. FaaS will support NRENs in building their identity federations by providing and hosting federation management tools on behalf of the NREN. The FaaS provides identity federation operators with tools to perform the registration of identity and service providers, including integration with eduGAIN. By providing these tools to the NRENs, they will be able to focus on building the AAl in their region by supporting the development of service provider and identity provider in member institutions. 
WACREN is supporting pilots in Identity Provider in GARNET (Ghana), NgREN (Nigeria), and SnRER (Senegal).

\section{Campus Networking - An Essential Building Block of a National Network}

Special mention should be made of the work of the NSRC from the University of Oregon whose work is largely funded by the NSF in the United States and by donations from corporations such as Google and Cisco. Teams from NSRC and their local partners and volunteers have been offering campus networking workshops across the globe for many years now, often at the time of regional REN meetings or meetings of regional network operators groups such as AfNOG. More and more, as skill levels increase among university and NREN technical staff, the training is in the form of Training of Trainers in an effort to bring their efforts to scale.

Another form of capacity building is the secondment of expert personnel from the advanced NRENs partners in Europe and in similar organizations to assist with specific phases of network development - mainly direct engineering assistance events, including equipment donations. 




\section{World Bank Education, Technology \& Innovation: SABER-ICT Technical Paper Series}

[1] SABER-ICT Framework Paper for Policy Analysis: Documenting national educational technology policies around the world and their evolution over time (Michael Trucano)

[2] Building and sustaining national ICT/education agencies: Lessons from international experiences (Michael Trucano \& Gavin Dykes)

[3] Building and sustaining national ICT/education agencies: Lessons from Korea (KERIS) (Youngsun Kwon \& Sanghyun Jang)

[4] Building and sustaining national ICT/education agencies: Lessons from Malaysia (Smart Schools) (Molly N.N. Lee \& Soon Seng Thah)

[5] The Role and Status of National Research and Education Networks (NRENs) in Africa (Michael Foley)

[6] Building and sustaining national ICT/education agencies: Lessons from England (Becta) (Gavin Dykes)

[7] Building and sustaining national ICT/education agencies: Lessons from Chile (Enlaces) (Eugenio Severin)

[8] Building and sustaining national ICT/education agencies: Lessons from Armenia (NaCET) (Edmond Gaible and Anush Shahverdyan)

[9] Building and sustaining national ICT/education agencies: Lessons from Uruguay (Plan Ceibal) (Eugenio Severin)

[10] Building and sustaining national ICT/education agencies: Lessons from Indonesia (PUSTEKKOM) (Neil Butcher \& Petra Bodrogini)

[11] Evoke -- Developing Skills in Youth to Solve the World's Most Complex Problems: The Social Innovators' Framework (Barbara Freeman \& Robert Hawkins)

[12] Technologies in education across the Americas: The promise and the peril - and some potential ways forward (Michael Trucano)

[13] Building and sustaining national ICT/education agencies: Lessons from Costa Rica (The Omar Dengo Foundation) (Carla Jimenez)

[14] Building and sustaining national ICT/education agencies: Lessons from Thailand (NECTEC/Schoolnet Thailand) (Saowaruj Rattanakhamfu)

[15] Building and sustaining national ICT/education agencies: Lessons from the Philippines (Benjamin Vergel De Dios)

[16] Building and sustaining national ICT/education agencies: Lessons from Australia (EdNA) (Gerald White \& Lesley Parker)

[17] ICT and the Education of Refugees: A Stocktaking of Innovative Approaches in the MENA Region. Lessons of Experience and Guiding Principles (Kent Lewis with Simon Thacker)

[18] Digital teaching and learning materials: Opportunities, options and issues (Michael Trucano)

[19] Developing Skills in Youth to Solve the World's Most Complex Problems: Contextualization, Implementation, and Experimental Research. Lessons from Evoke (Barbara Freeman \& Robert Hawkins)

[20] Developing Skills in Youth to Solve the World's Most Complex Problems: Applications and Sustainability. Lessons from Evoke (Barbara Freeman \& Robert Hawkins) 


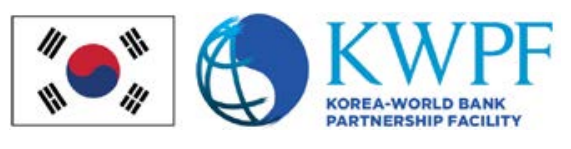

\title{
World Bank Education, Technology \& Innovation: SABER-ICT Technical Paper Series
}

\author{
@WBedutech \\ saber.worldbank.org \\ worldbank.org/education \\ blogs.worldbank.org/edutech \\ worldbank.org/en/topic/edutech \\ series coordinator: Michael Trucano
}

WORLD BANK GROUP 